\title{
La tradició editorial del Flos sanctorum català en el Cinccents
}

\author{
Carme Arronis Llopis
}

\author{
Universitat d'Alacant
}

arronis@ua.es

https://orcid.org/OOOO-OOOI-7635-O435

Received: 24/05/202I; accepted IO/O7/202I

DOI: https://doi.org/IO.7203/MCLM.8.20952

\section{The Publishing Tradition of the Catalan Flos Sanctorum in the Sixteenth Century}

\begin{abstract}
A first description of the sixteenth-century publishing tradition of the Catalan Flos Sanctorum. Based on the analysis of the extant copies, and the consultation of the existing bibliography, a panorama of dependencies and affiliations between the editions is presented, and each edition's innovations - mainly in terms of textual revisions and content variations-are described. This characterization aims to help find out what were the main efforts of publishers and booksellers in order to keep this textual product valid and attractive to the public, in a turbulent time which resulted in the replacement of medieval hagiographic compilations by new reformed ones.
\end{abstract}

KeYwords

Flos Sanctorum; hagiography; Jacobus de Voragine; Legenda Aurea; Carles Amorós; Jorge Costilla; Jaume Cendrat; early printing; Catalan culture

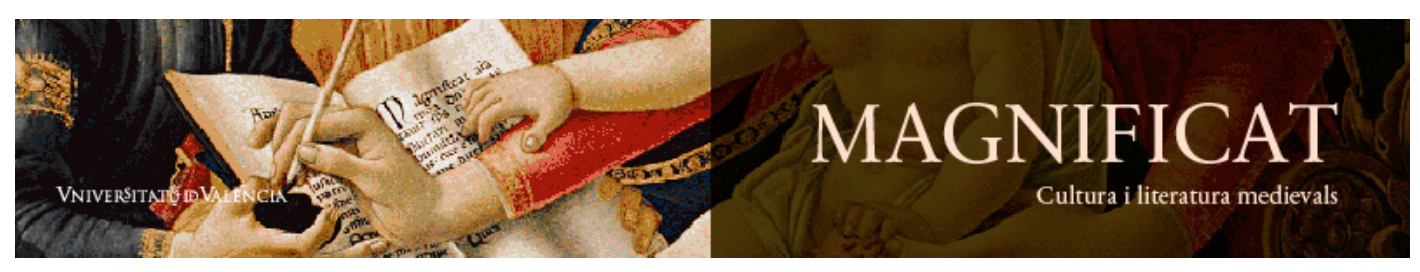

Magnificat Cultura i Literatura Medievals 8, 202I, 229-302. http://ojs.uv.es/index.php/MCLM

ISSN $2386-8295$ 
RESUM

Primera descripció de la tradició editorial cinccentista del Flos sanctorum català. A partir de l'anàlisi dels exemplars conservats, i de la consulta de la bibliografia existent, es presenta un panorama de dependències i filiacions entre les edicions, i es descriuen les novetats que incorpora cada edició, principalment quant a revisions textuals i variacions en els continguts. Aquesta caracterització permetrà esbrinar quins foren els principals esforços d'editors i llibreters per tal de mantenir el producte vigent i atractiu per al públic, en un període que finalitzà amb la substitució dels santorals medievals per altres de nous, reformats.

PARAULES CLAU

Flos sanctorum; hagiografia; Jacobus de Voragine; Legenda aurea; Carles Amorós; Jorge Costilla; Jaume Cendrat; edicions antigues; cultura catalana

Carme Arronis Llopis. 202I. 'La tradició editorial del Flos sanctorum català en el Cinccents', Magnificat Cultura i Literatura Medievals, 8: 229-302, DOI: https://doi.org/IO.7203/ MCLM.8.20952 (cc)BY

Aquest treball s'emmarca dins el projecte La hagiografía hispánica ante la Reforma protestante del Ministerio de Economía, Industria y Competitividad (FFI2Or7-86248-P).

\section{TAULA DE CONTINGUTS}

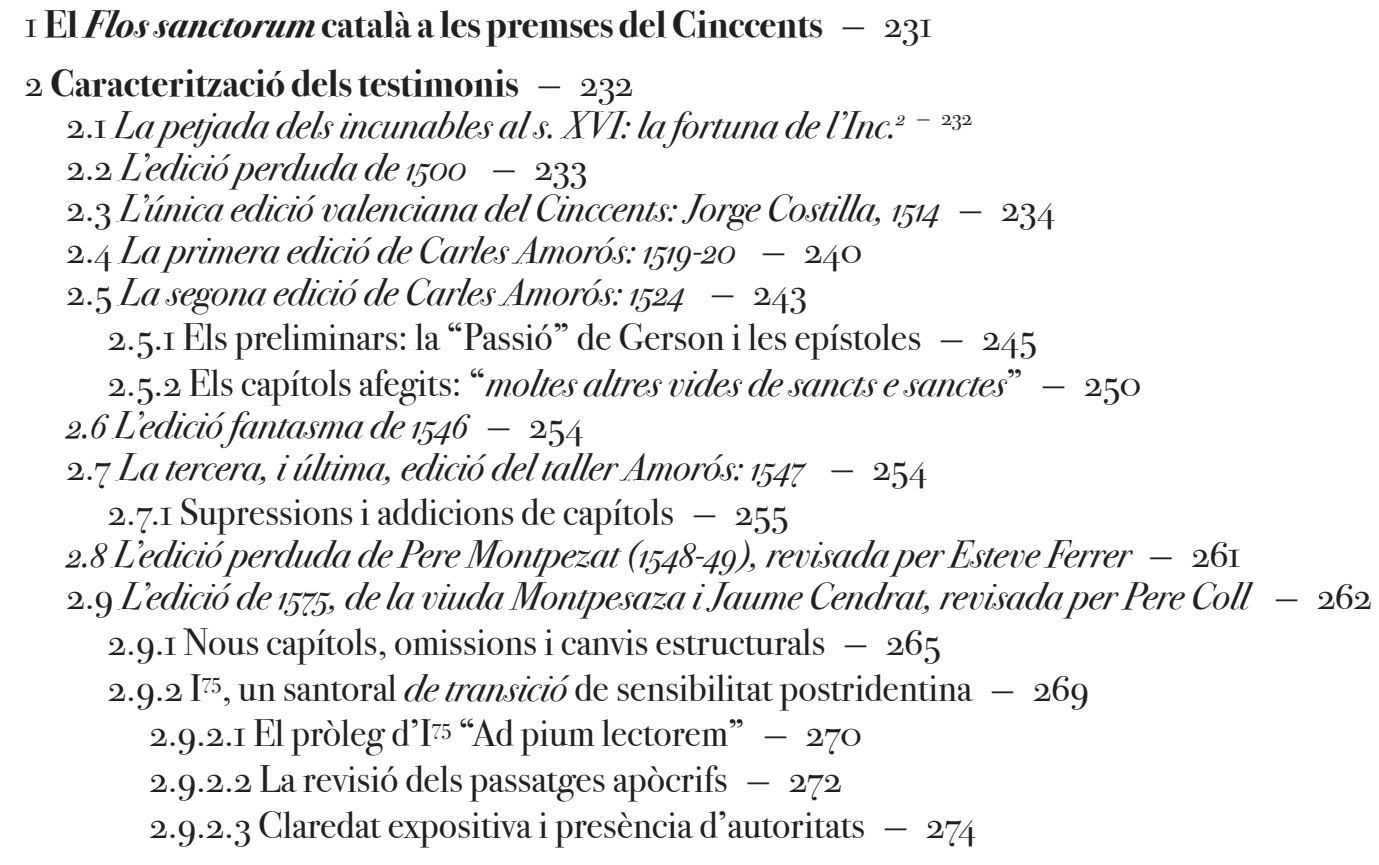

3. La desaparició de les compilacions generals en català de les premses - ${ }_{27} 6$

4. Conclusions -278

5. Obres citades -280

6. Annex: taules de correspondències - 284 6.I Taula 1: Correspondència de capítols de l'Inc ${ }^{2}$ i la LA - 284 6.2 Taula 2: Correspondències de capítols entre els santorals del Cinccents - 293 


\section{क*⿻丷木}

\section{El Flos sanctorum català a les premses del Cinccents}

A hores d'ara comptem amb nombrosos estudis que s'han ocupat de les traduccions catalanes medievals de la Legenda aurea $(L A)$ de Jacobus de Voràgine, i també amb edicions, tant dels testimonis manuscrits, com dels incunables. ${ }^{I}$ En canvi, la tradició editorial del Flos sanctorum català (FS) en el Cinccents fins ara ha estat poc atesa, i convé recordar que, especialment en la primera part del segle XVI, la versió romançada de la $L A$ encara era una obra principal per a la devoció popular, i cabdal en la literatura hagiogràfica; i, fins i tot, encara s'estampà per última vegada a Barcelona en I575, edició que s'encabeix en l'escàs I $2 \%$ de textos que s'imprimien en català a la ciutat en el darrer terç del segle (Garcia Sempere-Wilkinson 20I4: 64).

Els estudis que s'han referit a aquesta tradició editorial solen reproduir dades incompletes o poc exactes preses de la bibliografia anterior, i sovint sense constrastar-les amb els exemplars conservats. A més, la manera en què s’ha transmés la informació sobre les reedicions que es feren del $F S$ al Cinccents, ha propiciat la noció d'una tradició editorial lineal, en la qual, suposadament, cada edició reimprimia el text de la impressió immediatament anterior, cosa que no s'acompleix en tots els casos. ${ }^{2}$ Tampoc s'ha dit res de les suposades novetats que anuncien els títols de cadascuna de les edicions, per exemple, quant al tipus de revisions a què fou sotmés el text, o sobre els capítols nous que s'afegien en cada edició, normalment dedicats a sants de devoció local, que allunyaven cada vegada més el santoral català del corpus llatí primigeni per fer-lo més proper als lectors del moment.

Analitzar les transformacions que s'observen al llarg del Cinccents en un text devot de procedència medieval (ja que el gruix de la compilació va ser redactat entre ı260 i I298) presenta, doncs, un interés innegable, ja que, entre d'altres qüestions, permet esbrinar quins foren els esforços d'editors i llibreters per tal de mantenir el producte vigent i atractiu per al públic, i alhora, en els darrers temps, per procurar que fóra adequat a les noves directrius doctrinals que s'imposaven per a la matèria hagiogràfica després de la clausura del Concili de Trento. Recordem que, precisament al llarg d'aquest període, el culte als sants i els textos hagiogràfics foren centre de nombroses controvèrsies, i objecte de profundes revisions.

El FS català, però, ja no tornà a editar-se més enllà de I575, ja que el text medieval de Voràgine fou superat per les noves compilacions postridentines d'Alonso de Villegas (I578-93) i Pedro de Ribadeneira (I599-I604), que seguien el model de la compilació reformada de Lluís Lippomano i Llorenç Surio, ${ }^{3}$ i que ocuparen l'espai editorial del gènere a la Península. Convindria, per tant,

I. Fins a la data comptem amb les edicions, i els corresponents estudis, de diversos testimonis manuscrits, com les de Rebull (ı976), Maneikis Kniazzeh i Neugaard (ı977) i Garcia Sempere et. al (en premsa), i amb l'edició del text incunable (Càmara 2OI3). Vid. també els estudis de Garcia Sempere (2OIO, 2OI2a, 2OI2b i 2OI5), Avenoza i Garcia Sempere (2OI2) i Càmara (2OI7).

2. Per exemple, els esquemes d'Aragüés (2000: 369; 2004: 521 i 2005: I42), en què sintetitza la tradició romanç del Flos sanctorum hispànic en les diferents llengües peninsulars, pel que fa al cas del santoral català, plasma aquesta suposada idea de continuïtat i linealitat, que després, incorrent en algunes inexactituds, també han assumit autors posteriors, com Càmara (20I3).

3. Em referisc a la magna compilació del cartoixà alemany Llorenç Surio, De probatis sanctorum historïs (I57O75), que completava i reorganitzava el santoral de Lluís Lippomano, bisbe de Gènova (Sanctorum priscorum patrum vitae, I55-60); el santoral de Surio s'ha considerat el paradigma de la hagiografia reformada, o l'hagiografia crítica 
esbrinar si l'edició postridentina del $F S$ català presenta algunes característiques que s’allunyen respecte de les edicions precedents, com a conseqüència de l'adequació a un context espiritual sensiblement diferent, o si, essencialment, continua reproduint el text de l'edició incunable. Per aquesta raó, en la caracterització que presente en aquest estudi de les edicions del FS del Cinccents, l'última edició de la compilació ha merescut una atenció especial.

\section{${ }_{2}$ Caracterització dels testimonis}

A continuació oferisc una breu caracterització de les edicions del $F S$ català que s'imprimiren al segle XVI i de les quals s'ha conservat algun exemplar. He partit de l'anàlisi dels testimonis, tot $\mathrm{i}$ que he tingut en compte la bibliografia existent sobre la qüestió. He dedicat especial atenció a especificar la naturalesa de les revisions que s'aplicaren en diferents edicions, com també a detallar els principals canvis estructurals i de contingut que presenta cadascuna d'elles, dels que he procurat aportar informació sobre el tipus de relats afegits, el possible origen o l’interés a què semblen respondre.

També m'he fet ressò de notícies documentals relatives a edicions de les quals, a hores d'ara, no es compta amb cap exemplar, ja que considere que aquestes dades són necessàries per presentar un panorama editorial el més complet possible. Així mateix, he aclarit les notícies errònies que han portat a alguns estudiosos a afirmar l'existència de determinades impressions, quan en realitat es tracta d'interpretacions equívoques de les notícies documentals, sovint sorgides de l'encreuament de dades sobre altres exemplars.

De tot plegat es desprén que el $F S$ català s'estampà, després de les edicions incunables, en I5OO, I5I4, I5I9-2O, I524, I547, I548-49 i I575. L’ànalisi, a més, m’ha permés establir un esquema de dependències entre les edicions impreses, i encara que he pres com a punt de partida les hipotesis plantejades per Càmara (2OI3: LXI) i Baños (2OI8a: I79) sobre la filiació dels testimonis, apunte algunes matisacions, especialment pel que fa a l'edició de I5I4 (València, Jorge Costilla), que, però, només podran ser validades després d'un estudi ecdòtic sistemàtic i exhaustiu de tota la compilació.

\section{I La petjada dels incunables als. XVI: la fortuna de l'Inc. ${ }^{2}$}

$\mathrm{U}_{\mathrm{n}}$ na de les conclusions més evidents que podem traure de l'esquema de dependències del $F S$ a les premses del Cinccents, és que l’incunable publicat entre I490-94, probablement a Lió (d’ara en avant Inc. $\left.{ }^{2}\right)^{4}$ és el que tingué una major pervivència a les premses, més que l’Inc. ${ }^{1}$, imprés a

-terme proposat per Collins (2008: I33-I34)-, on se sintetitzaven els principals arguments de refutació a les crítiques protestants sobre la devoció als sants, i es posava en pràctica el mètode de revisió de la matèria per a la seua validació i legitimació.

4. Aquest incunable és incomplet tant per la part inicial com per la final, pel que no posseeix colofó; Càmara (2OI3: XLVI) arreplega les diferents propostes dels bibliòfils que han intentat datar-lo, i proposa com a data l'interval I49O-96: Johannes Trechsel, Lió, ca. I49O-94; Lope de la Roca, València, I496; o Pere Hagenbach, València, I496. Tanmateix, a la base de dades Iberian Books, després d'una anàlisi de l'exemplar, l'única hipòtesi que reporten és que es tracta d'una edició feta a Lió per Johannes Treschel, datada, per tant, entre I490-94 (IB I9697), i la mateixa conclusió es defensa a la base de dades Tipobibliografía valenciana ( ${ }^{\circ}$ I 43 , https://parnaseo.uv.es/imprenta/Textos/I24 Descripcion.pdf) on s’afirma que aquesta edició incunable "no utiliza material tipográfico que se empleara en Valencia”. Tanmateix, açò no fou impediment perquè l’obra circulara a la ciutat, ja que, gràcies a un document notarial de I495 (Arxiu del Real Col-legi del Corpus Christi de València, R-6o92), sabem que el llibreter Joan Taulet, resident en València, va comprar 
Barcelona en I494 per Joan Rosembach, que sembla que no tornà a estampar-se. ${ }^{5}$

Cal recordar que l'Inc. ${ }^{2}$ s'allunya més de la Legenda aurea medieval que l'Inc. ${ }^{1}$. Mentre que a l'Inc. 's'han suprimit només sis vides del nucli original de la $L A$ de Voràgine (de I 78 capítols), a l'Inc. ${ }^{2}$ han suprimit aquestes sis, i altres divuit vides més, ${ }^{6}$ és a dir, se n'han eliminat un total de vint-i-quatre. I així mateix, mentre que a l'Inc. ${ }^{I}$ s'han afegit vint vides noves, que no apareixien en el gruix de la $L A$, a l'Inc. ${ }^{2}$ se n’han incorporat encara altres cinc més (vint-i-cinc en total). Convé notar que molts d'aquests capítols nous s'inclouen en el cos del santoral (és a dir, no com un apèndix final), que recordem, està ordenat in circulum anni, seguint el calendari de les celebracions litúrgiques. Moltes d'aquestes noves vides corresponen a devocions ar relades al territori, i moltes ja n'apareixien en les versions manuscrites catalanes de la $L A$ (Garcia Sempere 20I5). La majoria s'ocupen de les vides de màrtirs de la Corona d'Aragó, per la qual cosa trobem la vida de santa Coloma, la vida de santa Eulàlia de Barcelona i el trasllat de les seues relíquies, les vides de sant Feliu i sant Cugat, la vida de sant Feliu de Girona, de sant Narcís, de santa Praxedis de Mallorca, entre d'altres. En altres casos, es tracta de devocions molt populars, per exemple per tractar-se de vides de sants i santes adalils de les ordes mendicants (com ara santa Clara, santa Caterina de Siena o sant Vicent Ferrer); per ser considerats especials protectors contra malalties (com és el cas de sant Roc, tingut per protector contra la pesta); o perquè, per altres raons, eren devocions especialment arrelades a la zona (com és el cas de sant Ponç, santa Tecla o santa Bàrbara, molt celebrats en territoris catalans). Aquesta tendència per fer-se ressò de les devocions locals, és general en la tradició editorial dels flores sanctorum romànics, i és una tendència, que, com veurem, continuarà consolidant-se a les premses al llarg del Cinccents.

Finalment, en tots dos incunables podem apreciar algun altre canvi respecte de l'estructura primigènia, per exemple perquè alguns capítols hagen estat desplaçats respecte del lloc que ocupaven en la $L A$, perquè un s'haja duplicat (hi apareixen dues versions de la vida de Feliu prevere [50] i [I23]), o perquè un capítol s’haja dividit en diversos, com ara el capítol "De sancto Pelagio papa” de la $L A$ [I77], que s'ha dividit en els incunables catalans en tres capítols diferents: a més del dedicat al papa Pelagi, s'han diferenciat "La hystòria de Mahomet" (és a dir, la història de Mahoma i l'origen de l'Islam), i "Dels reys de França" (la història dels reis francs i dels emperadors de l'imperi romanogermànic), episodis que en la $L A$ integraven un sol capítol (Càmara 2OI3: XLVIII).

\subsection{L'edició perduda de 1500}

Sembla que en I50o es va dur a terme, o almenys es va planificar, una nova edició d’un FS. Es conserva el document notarial signat el 3I de març de I5Oo entre els llibreters Joan Trinxer i Gabriel Pou i l'impressor castellà Sebastià d'Escòcia per estampar un flos sanctorum en català:

És concordat entre les dites parts, que lo dits Gabriel Pou e Sebastià d'Ezcoci hajen anpremptar CCCCL libres de Flor sanctorum en pla, ystoriats, posant en dita companya a quadascú sa part de

més de dos-cents exemplars per enquadernar-los i vendre'ls, a través d'un negoci amb el mercader savoià Antoni Rubinell, i el paperer Frank Ferber, residents tots dos a Barcelona i habituals del comerç internacional de llibres.

5. Càmara, editor i estudiós del Flos sanctorum romançat en el període incunable, fa servir les abreviatures I i i I ${ }^{2}$ per a referir-se a les edicions quatrecentistes. Tanmateix, atés que en aquest estudi em referiré a edicions incunables i a impresos del Cinccents, he preferit usar l'abreviatura Inc., per als incunables, i I, per als impresos posteriors. De l'Inc. ${ }^{1}$ ens han pervingut dos testimonis, un a la Biblioteca Nacional de Madrid (sig. I-200o), i un altre, a la Biblioteca de la Universitat de Barcelona (sig. inc. 687); l'únic testimoni de l'Inc. ${ }^{2}$ es conserva a la Biblioteca Espiscopal de Barcelona (sig. Inc. 58). Vegeu la caracterització codicològica d'Inc. ${ }^{2}$ a Càmara (2OI3: XLVI-LXI) i BITECA (manid 2206).

6. A les setze vides identificades per Càmara (2OI3: XLIX), caldria sumar les vides de sant Pancraci i de sant Segon, que també han estat suprimides. Vid. la taula I de l'annex. 
paper; e los dits stampadors hajen a métrer lurs treballs e altres coses necessàries que sien menester a obs de fer dits libres; e lo dit Johan Trincher, ultra la part sua del paper, té a donar X sous per rayma de paper stampada (...). E fets e stampats los dits libres, aquells se hajen a partir per terç entre los demunt dits de dita companya, ço és qualcú d'ells cL libres, al for que serà concordat per ells tots tres, e donar compte e rahó la hu a l'altre del que serà venut, tostemps que qualsevol d'ells ho requerís (...). E la dita companyia sia durable e dur fins tant los dits libres seran venuts (...). E que no puxen los dits stampadors fer més avant dels dits libres, sinó los dits CCCCL libres (Madurell-Rubió I955: 305, $\mathrm{n}^{\circ}$ I76).

Com no es coneix cap exemplar, no sabem quines característiques presentava, ni si és que finalment es va arribar a estampar.

\subsection{L'única edició valenciana del Cinccents: Jorge Costilla, 1514}

En I5I3 els impressors Jorge Costilla i Joan Vinyau s’associaren per estampar per al llibreter Joan Trinxer sis-cents exemplars del Flos sanctorum, que farien en acabar la "Vita Christi que ans de la dita concordia teníeu emprés” (Serano Morales I898-99: 96), però en realitat, aquesta societat durà poc, i finalment només Jorge Costilla escometé les impressions de totes dues obres. L'edició del FS que eixí del taller valencià de Costilla en I5I4 (I $\left.{ }^{\mathrm{I}}\right)$ s'anunciava al títol com revisada per mossén Catalunya (Flos sanctorum novament stampat corregit y ben examinat per lo reverent mossén Cathalunya, afegides certes vides que fins acín eren), i una primera aproximació al text revela que aquesta correcció i examen és de gran interés, atés que singularitza aquesta edició respecte de la resta de les edicions del $F S$ català. ${ }^{7}$

La revisió que s'aplicà a l'obra, de fet, és ben semblant a la que s'observa en l'edició del text de la Vita Christi d'Isabel de Villena que Costilla publicà només uns mesos abans, en I5I3. També en aquella ocasió en la portada es declarava que el text de l’abadessa havia estat "novament historiat, corregit y smenat per un mestre en sacra theologia”, ${ }^{8}$ el nom del qual, però, no es declarava: no sabem si potser poguera tractar-se d'aquest mateix mossén Catalunya. Com ja han apuntat diversos estudiosos, en l'edició de Costilla el text de la Vita Christi va ser esmenat en dues direccions: en paraules d'Escartí, d'una banda trobem un procés de "desaristocratització del llenguatge segurament per fer-lo més pròxim a capes més àmplies de lectors-", i de l'altra, amb una “esmena de castellanismes i substitució d’alguns mots per altres” (Escartí 20II: 39). Aquest interés de Costilla per adequar la llengua i l'estil dels textos que editava, el presenta com un dels impressors més interessants de la València del Renaixement. Malauradament, les seues produccions tingueren una fortuna editorial desigual: en el cas de la Vita Christi, la reedició que en féu Carles Amorós a Barcelona en $5_{52} 7$ sí que prengué com a base aquesta edició revisada per Costilla, però no ocorregué el mateix amb el Flos sanctorum, com veurem més endavant.

Fixant-nos, doncs, en les particularitats del text, en primer lloc observem que, efectivament, s'ha realitzat una revisió de naturalesa lingüística amb la intenció de modernitzar l'obra, probablement per fer-la més propera als devots valencians, de manera que les fórmules més arcaiques han estat substituïdes per altres que semblen ser més usuals a la València de la primera modernitat. Així

7. Es conserva un exemplar a la Biblioteca Històrica de la Universitat de València (R-I/3I5), i un altre a la Biblioteca Nacional de Catalunya (ı-VI-I9). Els dos exemplars són incomplets, el de València per pocs folis; precisament en tots dos falta el foli CCLXV, corresponent a la Història de Mahoma. Vid. la descripció a Tipobibliografía valenciana $\left(\mathrm{n}^{\circ} \mathrm{I} 43\right.$, https://parnaseo.uv.es/imprenta/Textos/I24 Descripcion.pdf) i BITECA (manid 2647), i algunes notícies més sobre les característiques tipogràfiques de l’imprés a Romero (2003).

8. Vid. la portada de l'exemplar R/3005 de la Biblioteca Nacional de España. 
"frares" passa a "germans"; "Blasi" a "Blay"; "Mallorques" a "Mallorca"; "sens" a "sense"; "sanct" a "sent"; "en continent" a "tantost"; i substantius com "lo trobament" o "lo degollament" passen a subordinades adverbials circumstancials del tipus "com fon trobada", "com fon degollat", o a infinitius substantivats: "lo trobar", etc. Pràcticament qualsevol fragment de l'obra permet evidenciar que el propòsit de l'actualització lingüística és una constant en la revisió del text, com es pot comprovar als passatges següents: ${ }^{9}$

\begin{tabular}{|c|c|}
\hline $\begin{array}{c}\text { Inc. }^{2} \\
{[66] \text { "Del trobament de la sancta creu" }}\end{array}$ & $\begin{array}{c}\mathrm{I}^{\mathrm{I}} \\
{[66] \text { "Del modo que fon trobada la santa creu }} \\
\text { de Jesuchrist" }\end{array}$ \\
\hline $\begin{array}{l}\text { E lig-se en una hystòria dels grecs que l’àngel } \\
\text { li donà del fust en què peccà Adam, e dix-li } \\
\text { que com levaria fruyt, que son pare seria } \\
\text { sanat (...). E Salamó manàll tallar, e féu-lo } \\
\text { metre en sa casa, mas, segons que diu Johan } \\
\text { Beleth, no s’i pogué bonament allogar en la } \\
\text { casa ne en negun altre loch, que no y fos curt } \\
\text { o lonc. E los maestres com ayrats, feren-lo } \\
\text { fora gitar, e feren-ne palanca en un passatge } \\
\text { on havia aygua. On com la regina de Sabba } \\
\text { vengués per oir de la saviesa de Salamó (...). } \\
\text { Puys ella dix a Salamó que en aquell fust } \\
\text { devia ésser penjat un home (f. XCvI }{ }^{b} \text { ) }\end{array}$ & $\begin{array}{l}\text { E lig-se en una hystòria dels grechs que } \\
\text { l’àngel li donà de l'arbre en què peccà Adam, } \\
\text { e dix-li que com levaria fruyt, que son pare } \\
\text { seria sanat (...). E Salamó manà'l tallar e } \\
\text { féu-lo metre en sa casa, mas, segons que diu } \\
\text { Johan Beleth, no s’i pogué bonament posar } \\
\text { en la obra, ne en negun altre loch que no y } \\
\text { fos curt o larch. E los mestres com ayrats, } \\
\text { feren-lo fora lançar, e feren-ne palanca en } \\
\text { un pas hon havia aygua. E com la regina } \\
\text { de Sabba vingués per oyr de la saviesa de } \\
\text { Salamó (...). Aprés ella dix a Salamó que en } \\
\text { aquell fust devia ésser penjat un home (...) (f. } \\
\text { xcixa) }\end{array}$ \\
\hline [Io6] "De sant Domingo" & 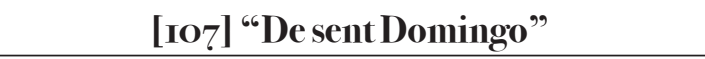 \\
\hline $\begin{array}{l}\text { Lo seu pare hagué nom Feliu, e la sua mare, } \\
\text { Johana, la qual, abans del seu naximent, véu } \\
\text { en somnis que ella portava un cadell cridant } \\
\text { en lo ventre, e tenia una falla de foc en la boca, } \\
\text { e, com ell fon nat, a ella fon vejarés que tot lo } \\
\text { món cremàs. E fon semblant a una dona qui·l } \\
\text { tengué a les fonts, que sant Domingo hagués } \\
\text { una stela en lo front qui il·luminàs tot lo } \\
\text { món. E dementre que era infant e·n guarda } \\
\text { de sa nudriça, era trobat moltes vegades en } \\
\text { terra nua jaent, que desemparava lo lit. (f. } \\
\left.\text { CXLV }^{c-d}\right)\end{array}$ & $\begin{array}{l}\text { Lo pare hagué nom Feliu, e la mare, Johana, } \\
\text { la qual, essent prenyada, véu en somnis } \\
\text { que ella portava un goçet en lo ventre, lo } \\
\text { qual tenia una falla de foch en la boca, lo } \\
\text { qual, essent nat, cremava tot lo món. E a la } \\
\text { padrina que·l batejà, li semblà que tenia } \\
\text { una stela en lo front que il·luminava tot lo } \\
\text { món. E essent fadrí de poqua edat, la dida, } \\
\text { que molt mirava per ell, moltes voltes lo trobà } \\
\text { dormint en terra havent deyxat lo lit. (f. } \\
\text { CLIIII }^{d} \text { ) }\end{array}$ \\
\hline
\end{tabular}

Si fem especial atenció al segon dels exemples, el de la vida de sant Domènec, comprovem a més que, a banda d’oferir mostres d'actualització lingüística (“cadell” per "gosset”, "nudriça” per "dida”, "jaent" per "dormint”; etc.), la revisió del text també intenta millorar la sintaxi per fer un text més entenedor. De fet, alguns paràgrafs, o fins i tot capítols sencers de l' Inc. ${ }^{2}$, que resulten de difícil comprensió, han estat reescrits amb una sintaxi més senzilla i ordenada, de manera que la lectura resulta molt més intel-ligible. S'aprecia especialment en l'acarament de capítols de major càrrega teològica, per exemple els tocants a festivitats cristològiques o mariològiques. Comprovemho en un fragment pertanyent a la festivitat mariana de la Purificació:

9. Faig ús de la negreta per destacar els canvis. 


\begin{tabular}{|c|c|}
\hline $\begin{array}{l}\text { Inc. }^{2} \\
\text { [4I] "De la Purificació de la verge Maria" }\end{array}$ & $\begin{array}{c}\mathrm{I}^{\mathbf{4} 4} \\
\text { [4I] "De la Purificació de la verge Maria" }\end{array}$ \\
\hline $\begin{array}{l}\text { Mas, què manà Déu que l’infant fos offert } \\
\text { al temple en lo quarante dia? Tres raons se } \\
\text { poden assignar. } \\
\text { La primera raó és perquè açò sia entés que, } \\
\text { axí com l'infant és portat en lo material temple, } \\
\text { axí en lo XL dia de la sua concepció moltes } \\
\text { vegades la ànima és compresa en lo cors, axí } \\
\text { com en lo seu temple, axí com és dit en la } \\
\text { Hystòria Scolàstica, jatsia açò que·ls phísichs } \\
\text { diguen que a XL dies és home perfet e acabat. } \\
\text { La segona és que la ànima és posada en } \\
\text { lo cors e aquí és tacada ella; e entrant en lo } \\
\text { temple al xL dia, per oblacions és denejada } \\
\text { de aquella taca. La terça és que açò sia donat } \\
\text { a entendre que aquells qui han ben servit } \\
\text { merexen entrar en lo celestial temple, qui } \\
\text { tenen los X manaments ab la fe dels quatre } \\
\text { Evangelis e aquells volran seguir. } \\
\text { E quant és feta dona són doblats los dies } \\
\text { quant a l'entrament del temple, e axí com se } \\
\text { doblen quant a la formació del cors, car lo cors } \\
\text { de l’hom mascle és acabat en XL dies e en lo } \\
\text { xL dia la ànima hi és scampada, e axí la fembra } \\
\text { hi és acabada en LXxx dia e lo LXxx dia hi és } \\
\text { scampada la ànima. } \\
\text { Mas, per què en doble se tarda de formar la } \\
\text { dona en lo ventre més que l'ome no? Per què y } \\
\text { és més tart scampada la ànima? Lexades totes } \\
\text { altres raons, se’n poden assignar tres raons. } \\
\text { La primera raó és per ço com Jesucrist devia } \\
\text { pendre carn e encarnament de home e, per ço } \\
\text { que home honràs e que més ampla gràcia li fes, } \\
\text { volgué que pus prest fos hom format e que la } \\
\text { mare no fos tan prest netejada. La segona raó } \\
\text { és per ço com la dona pecca més que l'home, } \\
\text { e, axí com los falliments són doblats defora en } \\
\text { lo món, que axíss deguessen doblar dedins en } \\
\text { lo ventre. La terça raó és que per ço és donat } \\
\text { a entendre que la dona en alguna manera } \\
\text { fatiga més a Déu que l’home per ço car la dona } \\
\text { més greument pecca que l’ome. Car Déu en } \\
\text { alguna manera és fatigat en les nostres obres } \\
\text { malvades, perquè ell diu “Servey me feu en } \\
\text { les vostres iniquitats”; encara més: “Treballs } \\
\text { sostén”. (f. LXl-b) }\end{array}$ & $\begin{array}{l}\text { E quant és dona són doblats los dies quant } \\
\text { al entrar del temple, axí com se doblen quant } \\
\text { a la formació del cos. Car lo cos de l'home } \\
\text { és acabat en XL dies, e en lo quaranten dia la } \\
\text { ànima hi és posada, e la fembra és acabada en } \\
\text { LXXx dies hi és posada la ànima. } \\
\text { Acíss demana una qüestió: per què són } \\
\text { doblats los dies en la dona e no en l'ome? A } \\
\text { d'aquesta demanda dient los doctors que per } \\
\text { tres rahons. La primera, perquè lo Fill de Déu } \\
\text { se havia de fer home e no dona, volgué més } \\
\text { honrar l'ome. }\end{array}$ \\
\hline
\end{tabular}

Hi ha, per tant, una revisió profunda del contingut del text per tal de millorar-ne la qualitat, que excedeix la mera actualització lingüística, i les intervencions que es fan en capítols com el 
que hem llegit suara, de qüestions teològiques complexes, indiquen que es tractava d'un revisor capaç d'interpretar-les adequadament i millorar-ne l'exposició, i fins i tot, de corregir algunes informacions errònies. Parem atenció a un cas concret. A la fi del segon paràgraf de la cita anterior, del capítol de la Purificació, hem vist com el revisor d'I I ha esmenat el que deia l'Inc. ${ }^{2}$ sobre l'opinió dels metges en relació a quan és format el cos de la criatura en el ventre de la mare: "en XLVI dies"; mentre que l' l'Inc. ${ }^{2}$, erròniament, tornava a reproduir la mateixa dada que indicava la Història Escolàstica: "a XL dies". S’esdevé, a més, que trobem aquesta lliçó errònia en tots dos incunables, és a dir, afecta tota la branca textual de les edicions catalanes impreses, i de fet, es manté en la resta d'edicions posteriors, fins a l'edició de I575 on s'esmena novament. ${ }^{\mathrm{Io}}$ És a dir, si I ${ }^{\mathrm{I}}$ no la conté, no és perquè no aparegués en el seu model, sinó perquè el revisor de l'edició de Costilla tenia a l'abast algun testimoni de major qualitat textual, potser llatí, al qual acudia per esmenar oracions o continguts carents de sentit, és a dir, que podia estar fent, en algunes ocasions, una revisió per emendatio ope codicum per recuperar l'afirmació correcta de la $L A$ :

\begin{tabular}{|c|c|c|c|}
\hline$L A$ & Inc. ${ }^{\prime}$ & Inc. $^{2}$ & $\mathbf{I}^{1 / 4}$ \\
\hline $\begin{array}{l}\text { I) licet physici dicant } \\
\text { quod in XLVI diebus } \\
\text { corpus perficiatur } \\
\text { ([37], 9; Maggioni ed. } \\
\text { 20O7: 278) }\end{array}$ & $\begin{array}{l}\text { jatsia açò que.ls } \\
\text { phísichs diguen que a } \\
\text { XL dies és home perfet } \\
\text { e acabat. } \\
\left([36], \text { f. XCI }{ }^{b}\right)\end{array}$ & $\begin{array}{l}\text { jatsia açò que.ls } \\
\text { phísichs diguen que a } \\
\text { XL dies és home perfet } \\
\text { e acabat. } \\
([4 \mathrm{I}], \text { f. LXI })\end{array}$ & $\begin{array}{l}\text { És ver que los metges } \\
\text { dien que en XIVI dies } \\
\text { és perfet e acabat lo cos. } \\
([4 \mathrm{I}], \text { f. LXI') }\end{array}$ \\
\hline
\end{tabular}

Aquesta premissa permetria plantejar una hipòtesi diferent sobre la filiació d'I ${ }^{\mathrm{I}}$ respecte de la proposada per Baños (2018a: I78-80). Baños suggereix, en base a criteris ecdòtics i iconogràfics, que, encara que derivarien d'una mateixa branca textual, ${ }^{\mathrm{I} 4}$ no sembla procedir directament d'Inc. ${ }^{2}$, sinó que tots dos haurien seguit un arquetip anterior, i que segurament seria un exemplar il.lustrat, les xilografies del qual totes dues edicions, Inc. ${ }^{2}$ i I ${ }^{\mathrm{I} 4}$, imitarien. Tanmateix, atés que $\mathrm{I}^{\mathrm{I} 4}$ ha estat profundament revisat per un editor entés, aquesta no em sembla una conclusió tan evident. Podríem plantejar-nos si els errors separatius a què es refereix Baños, que allunyen I ${ }^{\mathrm{I} 4} \mathrm{de} \mathrm{l'Inc.}^{2}$, generalment, oferint millors lectures que l'incunable, no serien conseqüència de la revisió del text davant oracions problemàtiques, és a dir, per emendatio ope codicum (com hem vist en l'exemple anterior) $\mathrm{o}$, fins i tot, per emendatio ope ingenü, pel mateix context oracional:

\begin{tabular}{|c|c|c|c|}
\hline$L A$ & Inc. ${ }^{I}$ & Inc. $^{2}$ & $\mathrm{I}^{\mathrm{I}}$ \\
\hline $\begin{array}{l}\text { 2) Beatus autem Lauren- } \\
\text { tius ipsum sequens post } \\
\text { eum clamabat: “Quo } \\
\text { progrederis sine filio, } \\
\text { pater? Quo, sacerdos } \\
\text { sancte, sine ministro } \\
\text { properas?" } \\
\text { ([II3], 39; Maggioni ed. } \\
\text { 2OO7: 842) }\end{array}$ & $\begin{array}{l}\text { mas sanct Lorenç lo } \\
\text { seguia dient: “On vas, } \\
\text { pare, sens ton fill? On } \\
\text { vas, prever sanct, sens } \\
\text { diaca?" } \\
\left(\left[\text { II5], f. CCV }{ }^{\text {b) }}\right.\right.\end{array}$ & $\begin{array}{l}\text { mas sanct Lorenç lo } \\
\text { seguia dient: “On vas, } \\
\text { pare sant (om.) ton fill? } \\
\text { On vas, prevere sant, } \\
\text { sens diaca?” } \\
([\text { IIO], f. CLXII') }\end{array}$ & $\begin{array}{l}\text { mas sent Lorens lo } \\
\text { seguia dient: "Hon vas, } \\
\text { pare sant, sense ton fill? } \\
\text { Hon vas, prevere sant, } \\
\text { sens diaca?" } \\
\text { ([III], f. CLX })\end{array}$ \\
\hline
\end{tabular}

IO. Es pot comprovar, per exemple, en l’edició de I547 (f. LXX). 


\begin{tabular}{|c|c|c|c|}
\hline $\begin{array}{l}\text { 3) Secundo } \\
\text { penes nostram } \\
\text { regenerationem; nam } \\
\text { primo puer exorcizatur } \\
\text { et baptizatur } \\
\text { et sic a peccato } \\
\text { mundatur } \\
\text { ([37], IOI; Maggioni ed. } \\
\text { 2OO7: 284) }\end{array}$ & $\begin{array}{l}\text { La segona manera és en } \\
\text { la nostra } \\
\text { regeneració, car, } \\
\text { primerament, l'infant } \\
\text { és exorcitat e axí és } \\
\text { mundat de peccat } \\
\text { ([36], f. XCII') }\end{array}$ & $\begin{array}{l}\text { La segona manera és en } \\
\text { la nostra regeneració, } \\
\text { car, primerament, } \\
\text { l'infant és exercitat e }_{\text {axí és mundat de peccat }} \\
([4 \mathrm{I}], \text { f. LXII })\end{array}$ & $\begin{array}{l}\text { Altra causa o segona } \\
\text { rahó donen los sancts: } \\
\text { que per causa del } \\
\text { Baptisme hon l'infant } \\
\text { és beneyt e de peccat } \\
\text { salvat ([4I], f. LXII') }\end{array}$ \\
\hline $\begin{array}{l}\text { 4) Nona loci preparatio; } \\
\text { Ioh. XIV: 'Vado parare } \\
\text { uobis locum'. } \\
\text { ([67], 2O7; } \\
\text { Maggioni ed. 2007: } \\
\text { 548) }\end{array}$ & $\begin{array}{l}\text { Lo IX profit és lo } \\
\text { apparellament del } \\
\text { loch, segons que diu } \\
\text { sanct Johan en lo XIII } \\
\text { capítol: "Vaig apparellar } \\
\text { a vosaltres loch" } \\
([68], \text { f. CXLV") }\end{array}$ & $\begin{array}{l}\text { Lo IX profit és lo } \\
\text { apparellament del } \\
\text { foc, segons que diu } \\
\text { sanct Johan en lo XIII } \\
\text { capi.: "Vaig apparellar a } \\
\text { vosaltres loch" } \\
\left([69], \text { f. } \text { cl }^{\text {b }}\right)\end{array}$ & $\begin{array}{l}\text { Lo IX profit és lo } \\
\text { aparellament del } \\
\text { loch: segons que diu } \\
\text { sent Johan en lo XIII } \\
\text { cap.: "Vaig aparellar a } \\
\text { vosaltres loch" } \\
([69], \text { f. CIIII") }\end{array}$ \\
\hline $\begin{array}{l}\text { Cuius mater ante ipsius } \\
\text { ortum } \\
\text { uidit in sompnis se } \\
\text { catulum gestantem in } \\
\text { utero ardentem in ore } \\
\text { faculam baiulantem } \\
\text { ([Io9], I2-I3; Maggioni } \\
\text { ed. 20O7: 804) }\end{array}$ & $\begin{array}{l}\text { Sanct Domingo fonch } \\
\text { duch de la orde dels } \\
\text { prehicadors e hagué } \\
\text { pare noble, e fonch } \\
\text { de Spanya, de la vila de } \\
\text { Caliruega (...) } \\
\text { (...) la mare del qual, } \\
\text { abans del seu naximent, } \\
\text { véu en somnis que } \\
\text { ella portava un cadell } \\
\text { cremant en lo ventre e } \\
\text { tenia una falla de fonch } \\
\text { en la bocha } \\
\text { ([III], f. CXCVII }{ }^{d} \text { ) }\end{array}$ & $\begin{array}{l}\text { (...), la qual, abans del } \\
\text { seu naximent, véu en } \\
\text { somnis que ella portava } \\
\text { un cadell cridant en lo } \\
\text { ventre, e tenia una falla } \\
\text { de foc en la boca, e, com } \\
\text { ell fon nat, } \\
\text { ([Io6], f. CLIIII }{ }^{\text {c-d })}\end{array}$ & $\begin{array}{l}\text { Sent Domingo fon } \\
\text { duch de la horde } \\
\text { dels preycadors. E } \\
\text { hagué pare de noble } \\
\text { generació, e fon } \\
\text { d'Espanya, de una vila } \\
\text { nomenada Calaforra } \\
(\text {...) } \\
(\text {...), la qual, essent } \\
\text { prenyada, véu en } \\
\text { somnis que ella portava } \\
\text { un goçet en lo ventre, } \\
\text { lo qual tenia una falla de } \\
\text { foch en la boca, lo qual, } \\
\text { essent nat, cremava tot } \\
\text { lo món. } \\
\text { ([IO]], f. CLIII }{ }^{\text {d) }}\end{array}$ \\
\hline
\end{tabular}

Com s'observa en els exemples exposats, només semblen haver estat revisats aquells casos que presenten una lliçó errònia evident, de manera que l'oració manca de sentit (vid. $\mathrm{n}^{\mathrm{o}} \mathrm{I}$ : sine / om., i n $^{\text {o }} 4$ : loci $\left./ f o c\right)$, tant, que fins i tot podrien esmenar-se per conjectura, sense que les solucions resultaren coincidents amb la $L A$, com ho evidencia l'exemple $n^{\circ} 3$ (exorcizatur / beneyt). En canvi, altres lliçons errònies, no tan evidents en la lectura, no han estat corregides, com ara la referència al versicle bíblic en el cas $\mathrm{n}^{\circ}{ }_{4}$ (Ioh. XIV / Johan en lo XIII cap.), o, en el cas $\mathrm{n}^{\circ}{ }_{5}$, l'al-lusió a un suposat noble llinatge de sant Domènec (per traducció incorrecta) o la denominació inexacta del lloc d'origen.

Encara que ací només n'oferisc un tast, he parat atenció a les lliçons errònies presents en l'Inc. ${ }^{2}$ que Càmara (2OI3: Apèndix VI.4) identifica, i he comprovat que la majoria d'elles es mantenen en $\mathrm{I}^{\mathrm{I}}$, perquè no resulten lliçons errònies evidents en la lectura del text. Malgrat tot, encara que pocs, alguns casos sí que han estat esmenats, sense que aquesta premissa s'acomplisca, com ho mostra l'exemple següent: 


\begin{tabular}{|c|c|c|c|}
\hline$L A$ & Inc. ${ }^{I}$ & Inc. $^{2}$ & $\mathrm{I}^{1 / 4}$ \\
\hline $\begin{array}{l}\text { 6) Ex hiis monasteriis } \\
\text { tria sursum in } \\
\text { rupibus montis erant, } \\
\text { que deorsum cum } \\
\text { magno labore aquas } \\
\text { hauriebant. Cumque } \\
\text { fratres illi uirum } \\
\text { dei sepe rogassent } \\
\text { ut monasteria illa } \\
\text { mutaret } \\
\text { ([48], 42; Maggioni ed. } \\
\text { 20O7: } 35^{8)}\end{array}$ & $\begin{array}{l}\text { D’aquells monestirs, } \\
\text { sanct Benet ne féu molt } \\
\text { alt en roques tres, e } \\
\text { havie-y aygua dels valls } \\
\text { de les muntanyes e, ab } \\
\text { molt gran treball, la } \\
\text { podien haver. On, com } \\
\text { los frares de aquells } \\
\text { monestirs pregassen } \\
\text { lo sanct baró que } \\
\text { mudàs los monestirs } \\
\left([49], f . c X^{c}\right)\end{array}$ & $\begin{array}{l}\text { D'aquells monestirs } \\
\text { sant Benet ne féu un } \\
\text { molt alt en roques, } \\
\text { e havia-y aygua dels } \\
\text { valls de les muntanyes } \\
\text { e, ab molt gran treball, } \\
\text { la podien haver. On, } \\
\text { com los frares daquell } \\
\text { monestir pregassen lo } \\
\text { sant baró que mudàs lo } \\
\text { monestir } \\
\left(\left[5^{2}\right], \text { f. LXXVI] }\right)\end{array}$ & $\begin{array}{l}\text { D'aquells XII } \\
\text { monestirs sent Benet } \\
\text { ne féu tres molt alts } \\
\text { en roques, e ab gran } \\
\text { treball pujaven l'aygua } \\
\text { de la vall. E los frares } \\
\text { molt sovint pregraven } \\
\text { sent Benet que mudàs } \\
\text { los monestirs } \\
\left(\left[5^{2}\right], \text { f. LXXVII }\right)\end{array}$ \\
\hline
\end{tabular}

Exemples com l'anterior, que certament són escassos, podrien avalar la hipòtesi de filiació proposada per Baños, i l'existència, doncs, d'un arquetip comú del que derivarien tant l'Inc. ${ }^{2}$ com $\mathrm{I}^{\mathrm{I}}$, perquè determinades variants textuals presents en $\mathrm{I}^{\mathrm{I}}{ }^{4}$, més pròximes a la $L A$, són difícilment explicables sense incorporar aquesta premissa, ja que no semblen respondre a la necessitat de revisar una lliçó problemàtica evident. ${ }^{.1}$ L'altra hipòtesi possible ens duria a pensar que els errors separatius d'I I ${ }^{\mathrm{I}}$ són resultat d'una revisió del text de l'Inc. ${ }^{2}$ per emendatio ope codicum i/o per emendatio ope ingenü, encara que no aplicada de manera sistemàtica, i no exclusivament per resoldre lliçons errònies evidents. Comptat i debatut, només un estudi ecdòtic exhaustiu de tot el santoral podria aportar una conclusió definitiva sobre la filiació d’aquesta edició valenciana, i validar una de les dues hipòtesis.

Tornant ara al contingut de la compilació, recordem que el títol d'I ${ }^{\mathrm{I}}{ }^{4}$, a banda d'anunciar que el text havia estat esmenat i corregit (tal i com hem comprovat), també indicava que havien estat "afegides certes vides que fins ací no eren". En realitat, però, només hi ha un sol capítol nou respecte de l'Inc. ${ }^{2}$, el que es dedica a la narració de la La hystòria dels deu mila [sic] cavallers crucificats ( $\left({ }^{14}\right.$ : ff. CXXII ${ }^{b}$ - CXXIIII $\left.{ }^{b}\right)$, martiri que, segons el Martirologi, es commemorava el 22 de juny, i de fet, a I ${ }^{\mathrm{I} 4} \mathrm{~s}$ 'ha introduït entre el capítol dedicat als màrtirs Gervasi i Protasi (I9 de juny) i el dedicat a sant Joan Baptista (24 de juny). Aquesta història gaudí d’una gran popularitat al Renaixement, i fou un motiu pictòric molt representat en el període. La narració que s’incorpora al santoral és d'una extensió considerable. S’inicia declarant el suposat origen de l'escrit, que, seguint la tradició més difosa, provenia de la traducció que del grec al llatí hauria fet "Anastasi, lo qual tenia en càrrech la libreria del Sant Pare, y envià-la a don Pere, Cardenal de Senta Sabina en Roma, en semblant estil”. Tot seguit es relata la història i el martiri d'Acaci i els cavallers romans que es convertiren al cristianisme. Una particularitat del relat és que, cap a la fi, reprodueix algunes mostres de la religiositat popular de caire supersticiós freqüents a l'època pretridentina, en incloure determinades promeses, o vanes observances, que aguarden als qui seran devots als cavallers màrtirs: com ara no morir de mort súbita, o ser visitat per àngels en l'hora de la mort, entre d'altres. ${ }^{12}$ Tant per l'encapçalament del relat, com per la cloenda, sembla que es tractava d'un relat

II. A més, també caldria tenir en compte les dependències iconogràfiques adduïdes per Baños (2OI8a) que refermarien l'existència d'un arquetip previ.

I2. "E diu lo sobredit cardenal que (...) tots los feels crestians los devem ser molt devots. E açò per IIII gràcies singulars que-ls seran atorgades: la primera, que seran nostres advocats e no morirem a mort sobtada; la II, que una volta, seran absolts de sos peccats y culpes; la III, que quant desta mortal vida partiran, los sancts los apareyxeran e ab les creus los defensaran del diable; la IIII gràcia, que si algun devot seu serà en purgatori, que ells recaptaran gràcia de 
que circulava exempt i que tenia un ús pietós; potser, atés l'interés que devia suscitar, fou incorporat al gruix de la compilació en la data escaient de l'any litúrgic. ${ }^{13}$

Per les principals característiques que hem descrit de l'edició realitzada per Jorge Costilla, revisada per mossén Catalunya, podem concloure que l'edició nasqué amb la clara ambició de superar les edicions incunables, acostant la llengua del text a la parla dels lectors, i simplificant la redacció feixuga, que sovint arrossegava males interpretacions i lectures dubtoses. I també pel format s'aprecia que era una edició ambiciosa -i costosa-, amb més d'un centenar de gravats i taula final de continguts (Canet 2005). Per tot plegat, doncs, l'edició de Costilla es revela com una de les edicions més interessants de la primera meitat del Cinccents. Tanmateix, sembla que aquest text no tornà a imprimir-se a València, i les edicions barcelonines que es feren anys després -com veurem tot seguit- no el feren servir. L'únic intent d'adequació del text als lectors del Renaixement, per tant, no tingué un gran ressò al mercat editorial.

\subsection{La primera edició de Carles Amorós: 1519-20}

De la que sembla ser la primera edició de Carles Amorós, feta a Barcelona entre I5I9 i I 520 , es conserva únicament un testimoni acèfal i incomplet. ${ }^{14}$ Coneixem el contracte, signat davant notari el I9 d'octubre de I5I9, entre Carles Amorós i el llibreter Bartomeu Aguilar, pel qual l'impressor es compromet a lliurar exemplars del Flos sanctorum en un termini de quatre mesos: "dare sibi unam balam papiri stampatam de libris dictis Flos sanctorum istoriatis, bonis e receptibilibus, sine dilacione” (Madurell-Rubió I955: 6o6, nº 349).

Aquest exemplar reprodueix molt fidelment l'Inc. ${ }^{2}$, i no s'hi observa cap tipus de dependència respecte de l’edició valenciana de Costilla de ${ }_{5}^{5}{ }^{\mathrm{I}} 4$, revisada per mossén Catalunya, ${ }^{15}$ que, com ja s’ha exposat, no tingué cap altra reedició. ${ }^{16}$ De fet, si fem atenció a les lliçons errònies que hem comentat més amunt, comprovem que només ha estat esmenat el cas $n^{\circ}{ }_{2}$, on s'havia omés un mot, ja que l'oració mancava de sentit, i el mot era fâcilment recuperable pel paral-lelisme amb l'oració següent:

Nostre Senyor qui.l deliure de les penes, y senta mare Església ayxí ho té, que per les oracions dels sants són deliurades les ànimes de les penes de purgatori” ( ${ }^{\mathrm{I}}{ }^{\mathrm{I}}: \mathrm{f}$. CXXIIII'). Sobre les oracions supersticioses i les vanes observances, vid. Londoño (2OI9).

I3. Sembla tractar-se d'una narració amb certa difusió i popularitat; una versió abreujada en castellà d'aquesta mateixa versió del martiri dels deu mil cavallers, apareix copiada, manuscrita, a la fi de l'exemplar mutilat del conegut com a Flos sanctorum renacentista castellà, el corresponent a l'edició prínceps, publicada a Saragossa per Jorge Cocci en I5I6 (l'exemplar es conserva a la Biblioteca Nacional de España, R-23859, vid. BITECA: manid 2643).

I4. El testimoni es conserva a la Biblioteca Lambert Mata de l’Ajuntament de Ripoll (signatura actual R.456; antiga, R. 206); vid. una descripció de l'exemplar a BITECA (manid 2648).

I5. Cal, per tant, descartar les afirmacions de Càmara (2OI3: XLI), que considera que les edicions barcelonines d’Amorós reediten el text valencià de Costilla revisat per mossén Catalunya.

I6. En canvi, quan Carles Amorós pocs anys després, en I527, estampà la Vita Christi d’Isabel de Villena, sí que prengué l'edició valenciana revisada de Costilla de I5I3 com a base, sobre la qual encara introduí algunes millores, com ara substituir els gravats de Costilla per altres de major qualitat (característica distintiva de les edicions d'Amorós), o una altra novetat ben interessant, incloure als marges la identificació de les fonts d'autoritat d'on procedien les citacions emprades per sor Isabel (Miquel i Planas I9I6: 3,377 ), un procediment que dotava de legitimat el text de l'abadessa, i que acabà sent imprescindible en els textos religiosos cap a la segona meitat de la centúria. 


\begin{tabular}{|c|c|c|}
\hline$L A$ & Inc. $^{2}$ & $I^{19-20}$ \\
\hline $\begin{array}{l}\text { I) licet physici dicant quod in } \\
\text { XLVI diebus corpus perficiatur } \\
\text { ([37], 9; Maggioni ed. 20O7: } \\
278 \text { ) }\end{array}$ & $\begin{array}{l}\text { jatsia açò que.ls phísichs diguen } \\
\text { que a xL dies és home perfet e } \\
\text { acabat. } \\
([4 \mathrm{I}], \text { f. LXI })\end{array}$ & $\begin{array}{l}\text { Jatsia açò que.ls phísics diguen } \\
\text { que a XL dies és home perfet e } \\
\text { acabat } \\
\left([4 \mathrm{I}], \text { f. } \mathrm{LXI}^{\mathrm{b}}\right)\end{array}$ \\
\hline $\begin{array}{l}\text { 2) Beatus autem Laurentius } \\
\text { ipsum sequens post eum } \\
\text { clamabat: "Quo progrederis } \\
\text { sine filio, pater? Quo, sacerdos } \\
\text { sancte, sine ministro properas?" } \\
\text { ([ı3], 39; Maggioni ed. 20O7: } \\
\text { 842) }\end{array}$ & $\begin{array}{l}\text { mas sanct Lorenç lo seguia } \\
\text { dient: "On vas, pare sant } \\
\text { (om.) ton fill? On vas, prevere } \\
\text { sant, sens diaca?" } \\
\text { ([II5], f. CLXII) } \\
\end{array}$ & $\begin{array}{l}\text { mas sanct Lorenç lo seguia } \\
\text { dient: “On vas, pare sant } \\
\text { sens ton fill? On vas, prevere } \\
\text { sant, sens diaca?” } \\
([\text { II5], f. CLXII') }\end{array}$ \\
\hline $\begin{array}{l}\text { 3) Secundo penes nostram } \\
\text { regenerationem; nam primo } \\
\text { puer exorcizatur et baptizatur } \\
\text { et sic a peccato mundatur } \\
\text { ([37], IOI; Maggioni ed. 20O7: } \\
\text { 284) }\end{array}$ & $\begin{array}{l}\text { La segona manera és en } \\
\text { la nostra regeneració, car, } \\
\text { primerament, l'infant és } \\
\text { exercitat e axí és mundat de } \\
\text { peccat } \\
\left([4 \mathrm{I}], \text { f. } \text { LXII }^{\mathrm{C}}\right)\end{array}$ & $\begin{array}{l}\text { La segona manera és en } \\
\text { la nostra regeneració, car, } \\
\text { primerament, l'infant és } \\
\text { exercitat e axí és mundat de } \\
\text { peccat } \\
\left([4 \mathrm{I}], \text { f. } \text { LXII }^{\mathrm{C}}\right)\end{array}$ \\
\hline $\begin{array}{l}\text { 4) Nona loci preparatio; Ioh. } \\
\text { XIV: 'Vado parare uobis locum'. } \\
\text { ([67], 2O7; Maggioni ed. 20O7: } \\
548)\end{array}$ & $\begin{array}{l}\text { Lo IX profit és lo apparellament } \\
\text { del foc, segons que diu sanct } \\
\text { Johan en lo XIII capi.: Vaig } \\
\text { apparellar a vosaltres loch" } \\
\left([69], \text { f. } \mathrm{Cl}^{b}\right)\end{array}$ & $\begin{array}{l}\text { Lo IX profit és lo apparellament } \\
\text { del foch, segons que diu sanct } \\
\text { Johan en lo XIII capi.: Vaig } \\
\text { apparellar a vosaltres loch” } \\
\left([69], \text { f. Cl }^{\text {b }}\right)\end{array}$ \\
\hline $\begin{array}{l}\text { 5) Cuius mater ante ipsius } \\
\text { ortum } \\
\text { uidit in sompnis se catulum } \\
\text { gestantem in utero ardentem in } \\
\text { ore faculam baiulantem } \\
\text { ([Io9], I3; Maggioni ed. 20O7: } \\
\text { 8O4) }\end{array}$ & $\begin{array}{l}\text { (...), la qual, abans del seu } \\
\text { naximent, véu en somnis que } \\
\text { ella portava un cadell cridant } \\
\text { en lo ventre, e tenia una falla de } \\
\text { foc en la boca } \\
\left.\text { ([Io6], f. CLIIII }{ }^{\mathrm{c-d}}\right)\end{array}$ & $\begin{array}{l}\text { (...), la qual, abans del seu } \\
\text { naximent, véu en somnis que } \\
\text { ella portava un cadell cridant } \\
\text { en lo ventre, e tenia una falla de } \\
\text { foch en la boca } \\
\left.\text { ([Io6], f. CLIII }{ }^{c-d}\right)\end{array}$ \\
\hline
\end{tabular}

Com l'exemplar és incomplet pel començament i pel final, no podem saber amb certesa si incorporava nous continguts respecte de l'edició incunable. Colomer (1995: 124) conjectura, basant-se en la presència d'un gravat de gran qualitat en el capítol de la Resurrecció de Crist $\left(I^{19}:\right.$ f. LXXX $\left.{ }^{b}\right),{ }^{17}$ que probablement aquesta primera edició d'Amorós ja inclouria a l'inici un seguit de preliminars pertanyents al cicle de la Passió que apareixen en les successives reedicions del santoral, atés que hi inclouen el mateix gravat de la Resurrecció. Tanmateix, aquest argument no em sembla suficientment sòlid per afirmar que $\mathrm{I}^{\mathrm{Ig-20}}$ ja contingués els preliminars, perquè hi ha altres consideracions -que exposaré més endavant en ocupar-me d'aquest afegit-, que apuntarien en sentit contrari.

Precisament, una particularitat d'aquesta edició barcelonina, i de les successives d'Amorós, és la incorporació d'una sèrie de gravats de gran qualitat i riquesa de detalls que substitueixen alguns dels que apareixien en les edicions incunables. Són, en paraules de Colomer, "un signe d'identitat de la seva producció” (I995: I24); de fet, Amorós tenia contractats a sou al seu taller especialistes en gravats, molts d'ells estrangers, fet que singularitza la riquesa gràfica de les seues edicions

I7. Es tracta d'un gravat de la Resurrecció que imita la calcografia de Martin Schongauer. 
(Lamarca 20I5: 37). Tenen l'amplària d'una columna i una altura de setze línies. Dels nous gravats que s'hi inclouen, destaquen aquells que presenten dues, o més, seqüencies de la història del sant, i que aporten un major caràcter narratiu, com també aquells que, amb gran luxe de detalls, reprodueixen interiors arquitectònics o paisatges naturals.

\section{I19-20}

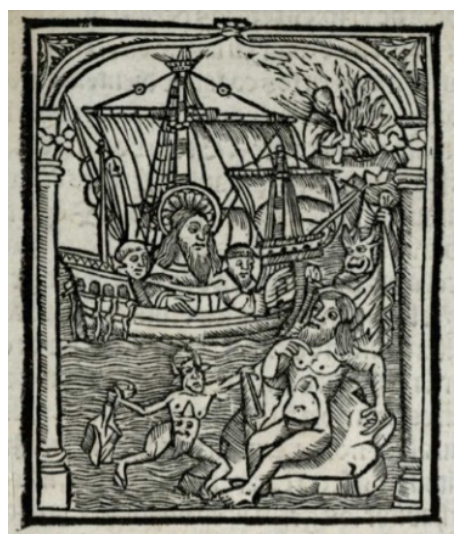

La vida de sanct Brandà $\left([2 \mathrm{O}]: \text { f. } \mathrm{XLI}^{\mathrm{a}}\right)^{18}$

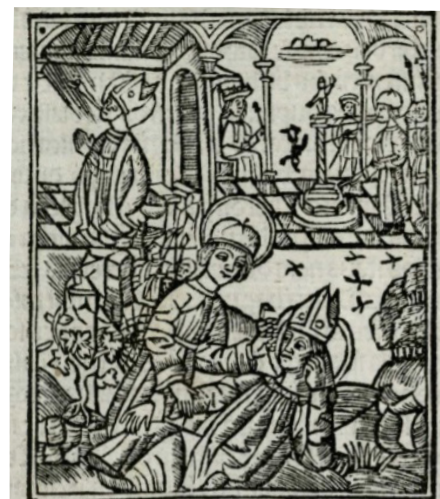

De sanct Feliu in pincis ([24]: f. XLII $\left.{ }^{\mathrm{d}}\right)$

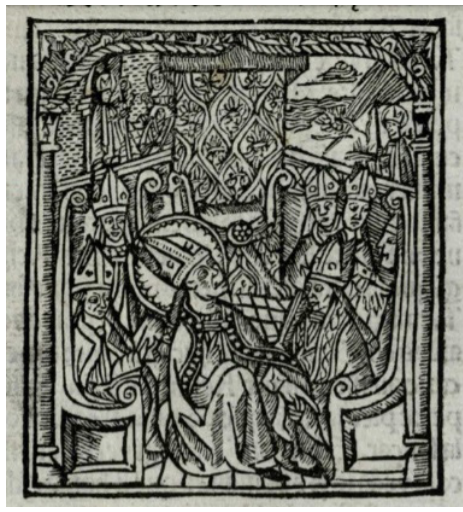

La vida de sanct Hylari ([22]: f. XXXXIII $)$

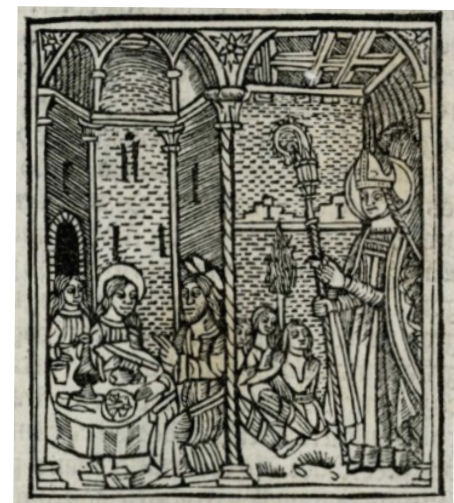

De sanct Julià ([32]: f. LIII $\left.{ }^{\mathrm{d}}\right)$

En canvi, no s'ha parat atenció al fet que, ben sovint, el tallista ha reproduït el mateix gravat que apareixia en l'incunable, però embellit amb detalls addicionals, com ara elements arquitectònics o detalls naturals dels paisatges:

I8. Les imatges d'I' ${ }^{19}$ procedeixen del fons Mata (456) de la Biblioteca Lambert Mata de Ripoll (CCo). 


\section{I'19-20}

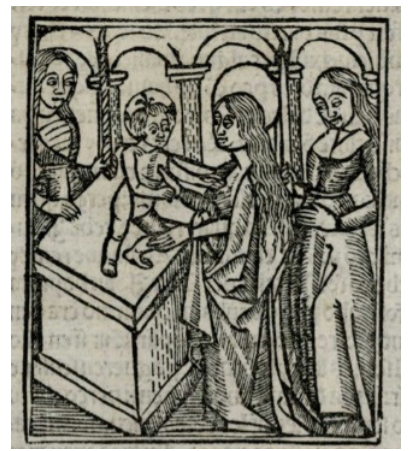

De la Purificatió de la Verge Maria ([4I]: f. LXI $\left.{ }^{\mathrm{a}}\right)$

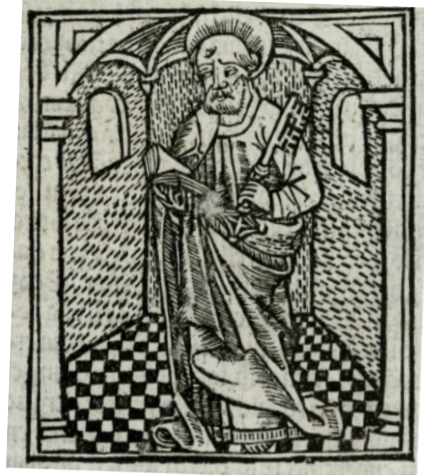

De la cadira de sanct Pere apòstol ([48]: f. LXVIII')

Es fa evident, doncs, que les il·lustracions són un dels principals reclams pels que aposta Amorós amb aquesta nova edició; en canvi, al text pràcticament no s'han introduït modificacions ni esmenes respecte del text de l’incunable, i es reprodueixen gairebé les mateixes lliçons errònies que hi eren presents.

\subsection{La segona edició de Carles Amorós: 1524}

$\mathrm{I}^{24}$ seria, per tant, la segona edició de què tenim notícia realitzada per Carles Amorós. ${ }^{19}$ A la portada es declara: Flos sanctorum novament fet e corregit, e afegit moltes altres vides de sancts e sanctes, ab la passió de nostre mestre redemptor Jesús. ${ }^{20}$ Com veiem, el títol, en primer lloc, declara que el santoral ha estat "novament fet e corregit", i efectivament, a pesar de tractar-se de dues edicions tan pròximes en el temps, comprovem que es tracta d'una nova composició, perquè la distribució del text en els folis no és la mateixa que en l'edició anterior; tanmateix, el text no sembla haver estat gaire corregit, i de fet, comprovem que les mateixes errades procedents de l'Inc. ${ }^{2}$ que s'havien mantingut en I'19-20 -vistes a l'apartat anterior-, es mantenen també en aquesta edició.

En canvi, s'hi ha posat, novament, molta cura en els aspectes formals, particularment en els gravats, senyal d'identitat del taller d'Amorós; paga la pena notar que, també en aquesta segona edició, es continua apostant per renovar-los per altres de major riquesa i detall -fins i tot respecte dels que ja s'havien incorporat en l'edició anterior-, o per afegir-ne de nous en algunes vides que no n’incloïen en les edicions precedents (com ara en la "Hystòria de Mahomet", [I77] f. CCXLVd):

I9. Tampoc en aquest cas s’edita la versió revisada per mossén Catalunya, com afirma Càmara (2OI3: XLI)

20. Es conserva un testimoni complet a la Biblioteca Universitària de Barcelona (fons de reserva $\mathrm{n}^{\circ} \mathrm{B}_{-5} 8 / 2 / \mathrm{I} 2$ ), i un altre, acèfal, i incomplet, a la Biblioteca de Catalunya (IO-VI-I8); vid. la descripció codicològica a BITECA (manid 2087). 
I19-20

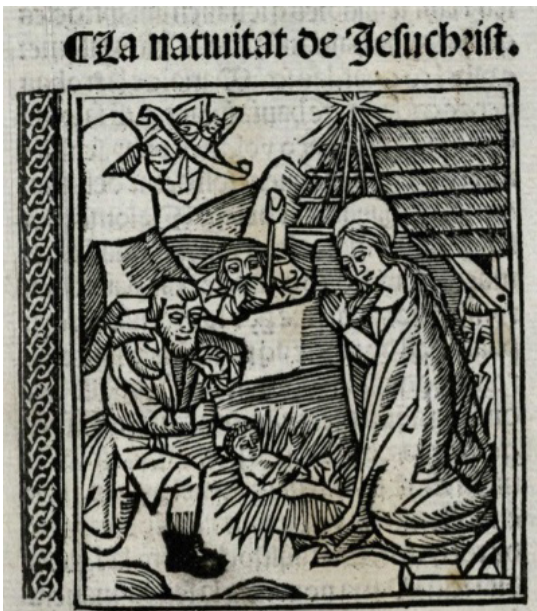

La Nativitat de Jesu Christ ([8]: f. XIX ${ }^{\mathrm{a}}$ )

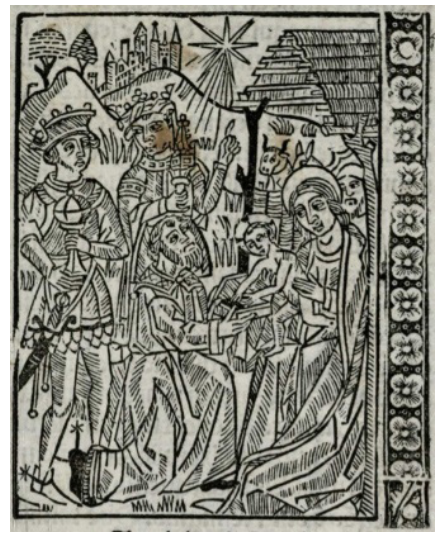

Com nostre Senyor apparegué als tres reys d'Orient

([I8]: f. XXXVI")

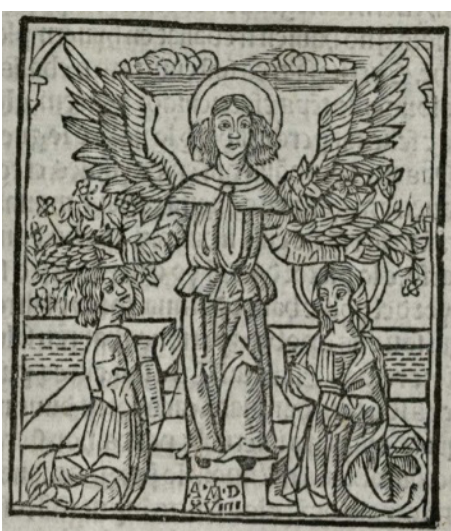

De sancta Cecília

([I57]: f. CCXXVI ${ }^{\mathrm{a}}$ )
$\mathbf{I}^{24}$

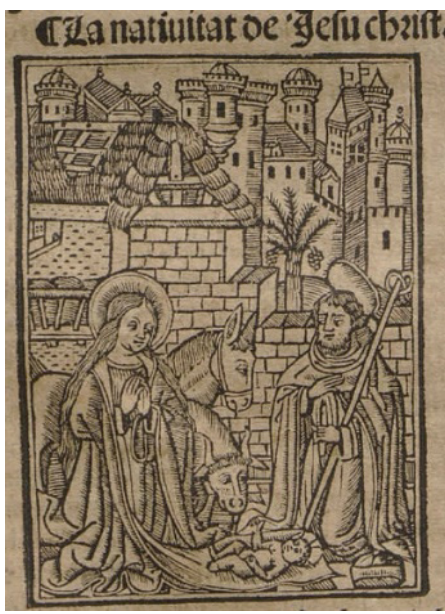

La Nativitat de Jesu Christ $\left([8]: \text { f. XIX }{ }^{\mathrm{c}}\right)^{2 \mathrm{I}}$

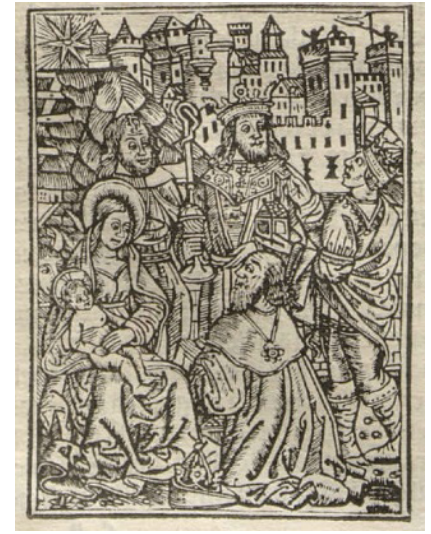

Com nostre Senyor apparegué als tres reys d'Orient

([I8]: f. XXXIIII ${ }^{\mathrm{c}}$ )

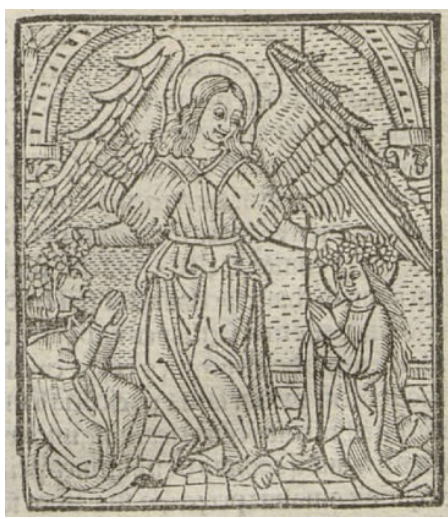

De sancta Cecília

([I57]: f. CCXV')

2I. Les imatges d'I'24 procedeixen dels fons de la Biblioteca de Catalunya (CCo). 
Però, sens dubte, el que més destaca del títol és que declara que s'hi han "afegit moltes altres vides de sancts e sanctes, ab la Passió de nostre mestre redemptor Jesús”. Analitzem, doncs, aquests nous continguts.

\subsection{Els preliminars: la "Passió" de Gerson i les epístoles}

Tal com indica el títol, aquest santoral inclou una Passió de Jesucrist a l'inici de la compilació, acompanyada d'altres textos breus de temàtica afí. Segons la hipòtesi de Colomer (I995: I24) referida més amunt, potser aquests preliminars ja s'haurien incorporat al santoral en l'edició anterior de I519-2O, però com l'únic exemplar conservat és acèfal, no es pot corroborar. A més, aquests preliminars, en totes les edicions que els contenen, conformen un quadern de deu folis independent que, a diferència de la resta del santoral, no posseeix numeració, pel que no resta traça de la seua presència en cas d'haver estat esgarrats.

Aquest quadern preliminar s'inicia amb la portada, que conté el títol general del santoral, seguit, al verso, d'un gravat, de mida de foli, que representa Crist crucificat. Els textos reunits són un breu avantpròleg general sobre la traducció "feta de latí en vulgar de aquella notable part del Monothesseron" de Joan Gerson (f. [2] $]^{\mathrm{a}}$ ); un pròleg específic de la Passió (f. [2] ${ }^{\mathrm{a}-\mathrm{c}}$ ); extractes de la Passió de Gerson, distribuïts en tretze episodis, cadascun dels quals acompanyat de gravats al.lusius al contingut (ff. [2] $]^{\mathrm{d}}-[9]^{\mathrm{d}}$ ); i dos epístoles finals relacionades amb el cicle de la Passió: la Letra de Publio Lèntul (...) als senadors de Roma (f. [Io]') i la Letra de Ponç Pilat (...) a l'emperador Tiberi (f. $\left.[\mathrm{IO}]^{\mathrm{r}-\mathrm{v}}\right)$.

La incorporació d'aquests preliminars al $F S$ era ben pertinent, atés que l'Inc. ${ }^{2}$ no contenia cap capítol dedicat a la Passió de Crist, ja que el capítol que li dedica Voràgine a la $L A$ havia estat omés en aquest incunable (Càmara 2OI3: XLIX) -i per tant, en totes les edicions que se’n deriven-. El tema de la Passió, a més, era un dels continguts més preuats en l'espiritualitat cristocèntrica i contemplativa característica del període tardomedieval, i de fet, en la tradició llegendària hispànica s'havia anat generalitzant la inclusió de textos cristològics que completaven la compilació de Voràgine, ja que Crist, i la seua Passió, era el model primer de tots els sants..$^{22}$ De fet, aquests preliminars afegits per Amorós al santoral són una traducció dels que havien estat incorporats a la popular Leyenda de los santos castellana ja cap a la fi del segle XV, enllestits -tots, o la majoria d'ellsper Gaubert Fabrici de Vagad, cronista oficial de Ferran el Catòlic, i que sembla que continuaren imprimint-se en les edicions successives de la Leyenda.$^{23}$ El primer testimoni conservat que presenta conjuntament els preliminars i el santoral, correspon a l'edició sevillana de Juan Varela de I520, i criteris ecdòtics i iconogràfics indiquen que, o bé fou aquesta l'edició que Amorós féu servir, o bé una molt propera que no s'haja conservat. ${ }^{24}$

22. En la tradició del FS castellà, per exemple, comprovem que, ja en alguns manuscrits del s. Xv, els capítols corresponents a festivitats cristològiques s'havien acrescut amb fragments procedents de la Vita Christi de Francesc Eiximenis, i que en les edicions cinccentistes aquests fragments foren substituïts per passatges de la Vita Christi del Cartoixà en la traducció d'Ambrosio de Montesino; a més, en la impremta esdevingué habitual que el santoral s’intitulara Vida de Cristo (...) y de sus sanctos, per tal d'evidenciar la seua preeminència (Aragüés 2OI2: 352-53).

23. Probablement aquests textos preliminars en castellà van ser preparats per a ser incorporats a unes edicions del FS dels tallers saragossans dels Hurus cap el I490 i el I492, però només s'han conservat uns preliminars impresos per Fadrique de Basilea a Burgos, probablement en I 493 (Aragüés 2OI6: 24-25 i Lacarra 2O2O: I23-I24). Totes les edicions castellanes de la Leyenda de los santos posteriors a I520 s'editaren amb aquests preliminars, que esdevingueren ben populars a la Península (Aragüés 2005: I27); també el Flos sanctõrum em lingoajem portugués, editat en Lisboa en I5I3 per Hermão de Campos i Roberto Rabelo, que traduïa la Leyenda de los santos, incorporava aquests preliminars cristològics (Aragüés 2005: 127).

24. Colomer (I999: I5) apunta que una edició de la Leyenda de los santos, feta en Toledo en I5II, de la que no s’ha 
L’edició d'Amorós redueix sensiblement alguns dels textos dels preliminars castellans, especialment el pròleg de la Passió, que guarda poca relació amb el text castellà; en canvi, l'avantpròleg que el precedeix, malgrat ser també una traducció lliure i abreujada, permet entreveure la dependència respecte del text de Vagad, l'autoria del qual s'omet:

\begin{tabular}{|c|c|}
\hline $\begin{array}{c}\text { Leyenda de los santos } \\
\text { [Avantpròleg dels preliminars] } \\
\left(\text { Sevilla, Juan Varela, } \mathrm{I}_{52}^{2 \mathrm{O}}\right)^{25}\end{array}$ & $\begin{array}{c}\mathbf{I}^{24} \\
\text { [Avantpròleg dels preliminars] }\end{array}$ \\
\hline $\begin{array}{l}\text { Comiença el prólogo del reverendo padre } \\
\text { Gauberte, sobre aquella esclarecida e famosa } \\
\text { obra que se hizo en Constancia, quando en } \\
\text { ella el Concilio General se tuvo, por aquel } \\
\text { aventajado e reverendo maestro en theología e } \\
\text { chanciller de París, Maestre Juan Gerson, que } \\
\text { se llama en griego Monotheseron, que es tanto } \\
\text { como dezir una de quatro ...y señaladamente } \\
\text { de aquella más que seràfica e divina, muerte } \\
\text { e passión que por nos padesció, que fue } \\
\text { trasladada del latín al común fablar de España } \\
\text { para la gente común de aquella. (...) } \\
\text { Y fue acordado que por entrada más } \\
\text { principal de todas las santidades y excellentes } \\
\text { vidas de todos los santos se pudiesse [sic] } \\
\text { luego en el comienço del libro que dellos } \\
\text { scrive, que fue nuevamente reconocido, } \\
\text { corregido y enmendado, la tan alta en } \\
\text { perfección de virtud, tan desigual, e subida, e } \\
\text { más que soberana magnanimidad: la muerte } \\
\text { e passión del Rey de los reyes y Señor de las } \\
\text { virtudes, Xhristo Jesú. } \\
\text { (...) Y dévese poner en la mano diestra } \\
\text { del que leyere, como una pujante, venturosa, } \\
\text { magnànima e siempre vencedora seña real } \\
\text { de los cavalleros de Dios, que son los santos } \\
\text { de Aquel. A cuyo especial esfuerço, amparo, } \\
\text { lumbre e favor pudieron ellos tan alta virtuosa } \\
\text { e maravillosamente vencer, no sólo el mundo, } \\
\text { y el diablo, e la carne, mas fasta los más altos } \\
\text { príncipes del mundo, que fueron los Césares } \\
\text { augustos en mando e poder (...) (Cabasés ed. } \\
\text { 2ooł: I-2) }\end{array}$ & 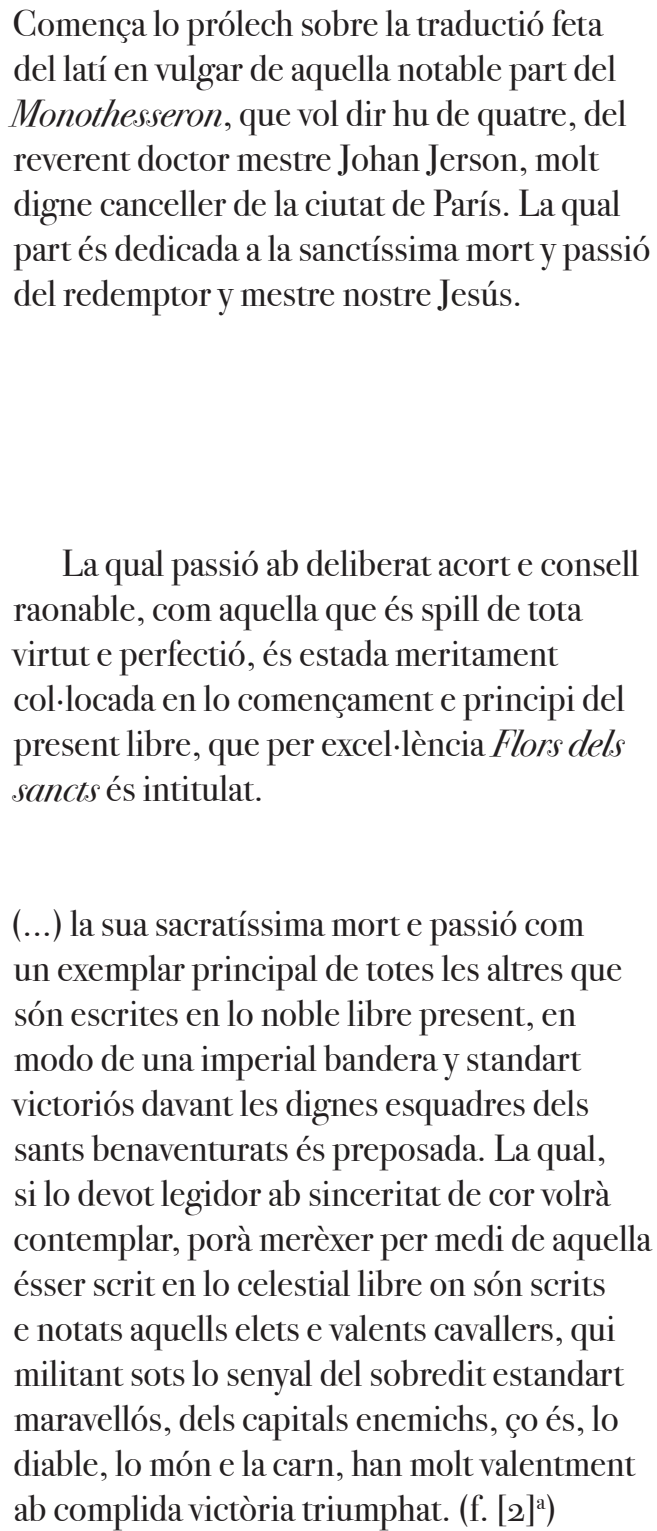 \\
\hline
\end{tabular}

En canvi, la traducció del text de la Passió de Gerson sí que segueix fidelment el text castellà. Es distribueix en els mateixos tretze capítols, que en el text català són numerats, i abracen els episodis principals de la Passió compresos entre Dimecres i Divendres Sant, fins al soterrament de Jesucrist.

conservat cap exemplar, podria ser responsabilitat del mateix Varela, actiu a l'època a la ciutat.

25. Col-lacione el text català amb l'edició de Juan Varela (Sevilla, I520), editada per Cabasés (2007) -i no amb la de Fadrique de Basilea (Burgos, I493?)-, perquè com argumentaré més endavant, criteris ecdòtics i iconogràfics posen de manifest la major proximitat que existeix entre el text català i l'edició sevillana. 


\begin{tabular}{|c|c|}
\hline $\begin{array}{l}\text { Leyenda de los santos } \\
\text { ["Pasión de Gerson"] }\end{array}$ & $\begin{array}{c}\mathbf{I}^{24} \\
\text { ["Passió de Gerson"] }\end{array}$ \\
\hline $\begin{array}{l}\text { De como fizo saber a sant Pedro que } \\
\text { le avía de negar, e de la contienda de los } \\
\text { discípulos }\end{array}$ & $\begin{array}{l}\text { Capítol quint. Com lo dulcíssim Jesús féu a } \\
\text { saber a sanct Pere que l'havia de negar, e de la } \\
\text { contenció que fon entre los seus dexebles }\end{array}$ \\
\hline $\begin{array}{l}\text { Díxoles entonce Jhesú: todos aquesta } \\
\text { noche seréys escandalizados en mi, ca } \\
\text { escripto es: herirán al pastor y derramarse } \\
\text { han las ovejas del hato. }{ }^{26} \text { Mas después de } \\
\text { resuscitado yo me yré adelante e os esperaré } \\
\text { en Galilea. Respondió sant Pedro, e díxole: } \\
\text { "Aunque todos sean escandalizados en ti, yo } \\
\text { nunca lo seré”. Díxole entonces Jesú: “Antes } \\
\text { que el gallo esta noche dos vezes cante, me } \\
\text { negarás por tres vezes" (Cabasés ed. 20O7: } \\
\text { II) }\end{array}$ & $\begin{array}{l}\text { Alhora Jesús los dix: Aquesta nit sereu } \\
\text { escandalitzats en me, per quant scrit és: } \\
\text { feriran lo pastor e dispergir se han del ramat } \\
\text { les ovelles. Mas pus seré ressuscitat yo davant } \\
\text { vosaltres en Galilea. Responent adonchs } \\
\text { Symon Pere, li dix: "Encara, Senyor, que } \\
\text { tots los altres fossen escandalizats en tu, yo } \\
\text { nunqua me escandalizaré". Al qual dix Jesús: } \\
\text { "Abans que lo gall haje cantat dues vegades, } \\
\left.\text { tres vegades me negaràs" (f. [3] }]^{\mathrm{d}}\right)\end{array}$ \\
\hline
\end{tabular}

Convé notar, a més, que en l'edició d'Amorós s'han imitat la majoria dels gravats presents en els capítols de la Passió de Gerson, però, en concret, els gravats que apareixen en l'edició de Varela de I520, i no els que apareixen en la versió incunable dels preliminars (Burgos, Fadrique de Basilea, I493?). ${ }^{27}$ En altres casos, en canvi, sembla que Amorós disposava ja al seu magatzem d'alguns gravats de la mateixa temàtica, un parell dels quals (al-lusius a la Crucifixió i la Resurrecció, que imiten les calcografies de Martin Schongauer) de gran qualitat, per la qual cosa decideix reaprofitarlos en els capítols de la Passió pertinents, en lloc d’imitar els de la font:

\section{$\mathbf{I}^{24}[$ Preliminars]}

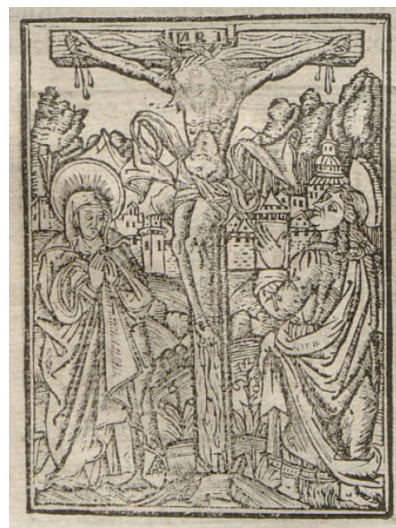

[Crucifixió] (f. [8]')

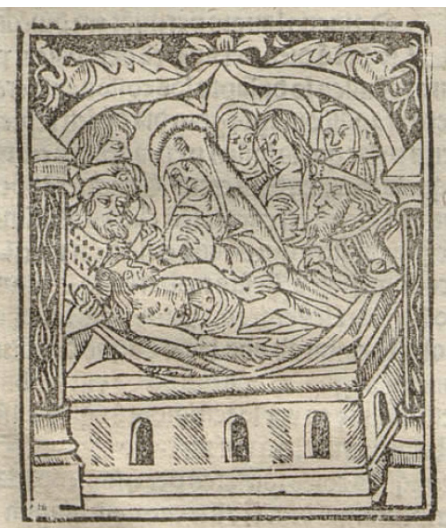

[Sepulcre] (f. [9] $\left.]^{\mathrm{c}}\right)$

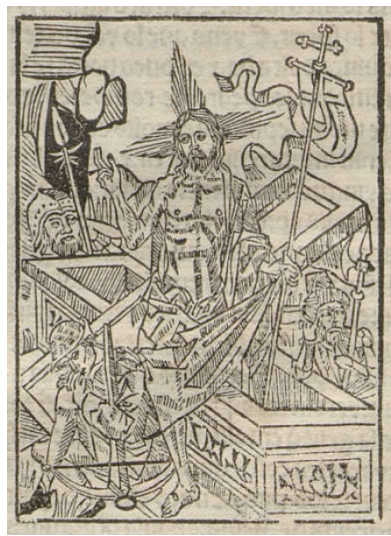

[Resurrecció] (f. [9] d)

26. En el testimoni dels preliminars imprés per Fadrique de Basilea a Burgos en I493, en canvi, es llegeix: “Feriré el pastor y derramarse han las ovejas del ato" (f. [6] $]^{\mathrm{c}}$. Aquesta variant del passatge és un exemple que permet mostrar la major proximitat entre l'edició de la Leyenda de 1520 i I²4.

27. Aquesta dependència s’aprecia particularment en alguns capítols, com ara en el del Sant Sepulcre, en què, clarament, el text català imita el gravat de Varela, diferent del de l’incunable. Els gravats dels preliminars impresos per Fadrique de Basilea es poden consultar en l'exemplar conservat en la Boston Public Library (https://go.uv.es/ rieZ2jQ); els gravats de l'edició de I520 de Juan Varela de Salamanca es reprodueixen en l'edició de la Leyenda de los santos editada per Cabasés (2007). 
Aquest aprofitament de les xilografies em fa posar en dubte la hipòtesi de Colomer (I995: I24) sobre la suposada existència dels preliminars ja en l'edició precedent d'Amorós, ${ }^{19-20}$; aquesta hipòtesi parteix del fet que, atés que en $\mathrm{I}^{24} \mathrm{el}$ gravat referent a la Resurrecció apareix dues vegades, en el capítol corresponent, i en els preliminars, Colomer conclou que la seua presència en I ${ }^{19-20}$ seria la mateixa -en totes dues ocasions-. Però la conclusió no és tan senzilla. Potser, si Amorós ja disposava d'aquesta matriu al seu taller, podria donar-se el cas que l'usara en I I9-20 només en el capítol de la Resurrecció, mentre que, en I ${ }^{24}$, també l'incloguera en els preliminars. Cal constatar que aquest gravat, a més, realment no té cabuda en el text de la Passió de Gerson, ja que la narració finalitza amb el soterrament de Crist. I de fet, l'edició de Varela no inclou cap gravat que represente la Resurrecció. Per tant, l'afegit de la imatge sembla ser una iniciativa d'Amorós, i no venir condicionada per la font.

D’altra banda, també tenim el problema de les dates. El text, i les imatges, dels preliminars d'Amorós d'I24, són més fidels als que apareixen en els preliminars de l'edició de la Leyenda de los santos de I $_{2}^{20}$, que no als de l'edició incunable. És cert que podria haver-se fet alguna altra edició de la Leyenda anterior a la de I520 que incloguera els preliminars, de la qual no se n'han conservat notícies, ni exemplars. ${ }^{28}$ Però és que, a més, comptem amb més evidències textuals que podrien relacionar estretament l'edició sevillana de $\mathrm{I}_{52} 2 \mathrm{O}$ amb I ${ }^{24}$, com veurem tot seguit, en ocupar-nos dels capítols afegits. Comptat i debatut, sembla més probable que ${ }^{24}$ fóra la primera edició a la qual s'afegiren els preliminars cristològics que es reeditaran en la resta d'edicions posteriors, i tot apunta a que es prengueren de l'edició sevillana de Juan Varela de I520.

Tornant ara a la resta de preliminars, en realitat, el gravat de la Resurrecció que apareix a I ${ }^{24}$ s'aprofita per separar la narració de la Passió dels textos següents: ${ }^{29}$ dues epístoles finals de temàtica crística, que s’introdueixen en el text català explicitant que "són estades tretes o copiades en lo archiu de la sglésia de Sancta Creu de Roma, de un libre qui és intitulat Manual de sancta Helena" $\left(\mathrm{I}^{24}:\right.$ f. $\left.[9]^{\mathrm{d}}\right)$, informació que no apareix en el text castellà. I és que, de fet, les epístoles catalanes han estat una mica ampliades respecte del text castellà; potser l'editor disposava d'altres materials complementaris, perquè les dues epístoles foren molt difoses a les darreries de l'edat mitjana en tot l'àmbit hispànic. ${ }^{30} \mathrm{~A}$ més, l'estil de la traducció del text de la Passió, i de les epístoles, és sensiblement diferent, ja que la prosa de les cartes, com ja va notar López Casas (I998: 367 i r999: 308), recorda la prosa valenciana artitzada de les darreries del segle XV.

28. Vid. nota 24 .

29. A I ${ }^{24}$ no s'ha inclòs l'oració al crucifix que segueix el text de la Passió, i que apareix en els preliminars de la Leyenda de los santos de I520 (a l’edició incunable, en canvi, n’eren dues, una breu, en llatí, i un altra, més extensa, en castellà).

30. Aquestes dues epístoles apòcrifes degueren ser força populars a l'edat mitjana; això explicaria que, per exemple, el cartoixà Ludolf de Saxònia inclogués al pròleg de la seua Vita Christi la carta de Lèntul, fet, que no féu sinó afavorir encara més la difusió d'aquest escrit, ja que també fou traduït en les versions en romanç de la Vita Christi-com per exemple en la que féu Joan Roís de Corella. Ferrer (20IO: 58) considera que el traductor d'aquesta "epístola de Lèntul" que llegim a I²4, coneixia la de Corella, del qual imita l'estil traductològic i les possibilitats per amplificar-la, no tant les solucions concretes. Bizarri i Sainz (1994) ja demostraren que la carta de Lèntul tingué difusió a la Península també de manera independent, i no hem de descartar que en l’àmbit català també circularen diverses versions. 


\begin{tabular}{|c|c|}
\hline $\begin{array}{l}\text { Leyenda de lossantos } \\
\text { [Preliminars] }\end{array}$ & $\begin{array}{c}\mathbf{I}^{24} \\
\text { [Preliminars] }\end{array}$ \\
\hline Publio Léntulo... a los senadores de Roma & $\begin{array}{l}\text { Publio Lèntul... als senadors i ciutadans de } \\
\text { Roma }\end{array}$ \\
\hline $\begin{array}{l}\text { (...) Tiene crencha por medio de la cabeça a } \\
\text { fuer de los nazarenos. Tiene la frente llana e } \\
\text { muy serena, con la faz sin ruga o tacha alguna, } \\
\text { a la qual fermosea un mediano color. En la } \\
\text { nariz ni en la boca no ay qué decir. (Cabasés } \\
\text { ed. 2007: 27) }\end{array}$ & $\begin{array}{l}\text { (...) Té una clenxa per mig del cap a usança } \\
\text { dels nazarens. Té la front plana, serena e } \\
\text { condecentment espaciosa, ab la faç, com he } \\
\text { dit, sens ruga o alguna taca. Lo nas té dret e } \\
\text { perfetament col-locat, lo qual per una gentil } \\
\text { egualtat e mesura li parteix les galtes, les } \\
\text { quals són tant formoses que no crech sie cosa } \\
\text { més amable e delectable a la vista; a la qual } \\
\text { formosura és adjunt un mijancer e onestíssim } \\
\text { color. (f. [ıo]') }\end{array}$ \\
\hline Carta de Poncio Pilato al Emperador Tyberio & $\begin{array}{l}\text { Lletra de Ponç Pylat tramesa a l'Emperador } \\
\text { Tiberi }\end{array}$ \\
\hline $\begin{array}{l}\text { (...) como ya la multitud del pueblo dixesse él } \\
\text { ser fijo de Dios, alçáronse otros contra él por } \\
\text { embidia, mintiendo. E algunos dixeron que } \\
\text { era adevino y encantador, e que fazía contra } \\
\text { su ley. }\end{array}$ & $\begin{array}{l}\text { (...) e com ja la moltitut del poble confessàs } \\
\text { e digués aquell ser Fill de Déu, los majors, } \\
\text { ço és, los doctors phariseus letrats, e més } \\
\text { encians del poble, per pura malícia y enveja } \\
\text { se alçaren contra ell, donant entendre al } \\
\text { poble ésser aquell nigromàntic, encantador } \\
\text { e subvertidor de la lur ley, e induir en lo } \\
\text { poble ab ses instigacions e mentides en } \\
\text { tal manera contra ell, que ab gran avalot lo } \\
\text { prengueren ell presentaren davant la mia } \\
\text { audiència, fent instància molt gran, que yo·l } \\
\text { sentenciàs a mort, dient-me que segons sa }\end{array}$ \\
\hline $\begin{array}{l}\text { E yo, dando fe a las palabras dellos, e creyendo } \\
\text { ser así, entreguégelo para que le açotassen a } \\
\text { su guisa. }\end{array}$ & $\begin{array}{l}\text { ley devia morir. E yo, donant fe a les paraules } \\
\text { dels sobirans e principals sacerdots, lo fiu en } \\
\text { tal manera acotar, que restava a mon parer } \\
\text { suficientment castigat. Emperò, los malvats } \\
\text { jueus, plens de malícia e iniquitat, no contents } \\
\text { de açò, començaren de moure e avalotar lo } \\
\text { poble, cridant a grans crits e clamors que·l fes } \\
\text { crucificar e morir. E yo, conexent clarament } \\
\text { no èsser digne de mort, treballí molt segons } \\
\text { ma possibilitat en placar-los. Mas ells no·m } \\
\text { volien solament scoltar, ans molt més se } \\
\text { indignaven, e cridaven menaçant de inimicar- } \\
\text { me ab la tua imperial Senyoria. Alhora, } \\
\text { veent yo que tot lo poble se avalotava, e no } \\
\text { aprofitaven res mes paraules, laví-me’n les } \\
\text { mans e liuríl en lurs mans, dient-los que·n } \\
\text { fessen lo que·n volguessen a lur guisa. E axí } \\
\text { ells lo crucificaren cruelment en un fust dur e } \\
\text { molt aspre. (f. [ro]v) }\end{array}$ \\
\hline
\end{tabular}

En qualsevol cas, i malgrat les amplificacions del text català, la presència de determinades lectiones difficiliores en tots dos textos, especialment en el de Lèntul, semblen evidenciar que estan 
emparentats (López Casas 1998: 367-68). ${ }^{3 \mathrm{r}}$ Convé notar que en l'edició d’Amorós les epístoles s'han disposat a l'inrevés respecte del text castellà: primer apareix la de Lèntul, i després, la de Pilat, és a dir, seguint l'ordre cronològic més lògic, atés que la lletra de Lèntul és una prosopografia de Jesús dictada quan encara és viu, i la de Pilat, en canvi, dóna notícia de la mort i dels rumors de la Resurrecció. Pel que fa al format, sorprén que les dues epístoles siguen l'únic contingut del santoral que no es distribueix en dues columnes, no sabem si perquè les planxes respectives haguessen estat enllestides prèviament.

\subsubsection{Els capítols afegits: "moltes altres vides de sancts e sanctes"}

Finalitzat el primer quadern que conté els preliminars, s'inicia el santoral pròpiament dit. De fet, el foli Ir és una nova portada, que presenta en el recto el rètol Flor dels sants i un gravat de la Mare de Déu de la Llet acompanyada d’àngels, i, en el verso, un gravat del Judici Final. Aquest títol de Flor dels sants, que sembla original de les edicions d'Amorós -l'edició anterior és acèfala i no podem saber si ja l'inclouria-, acabarà imposant-se en les reedicions posteriors, en comptes de la fórmula llatina Flos sanctorum, de procedència medieval.

Al títol també es declara que s'hi han "afegit moltes altres vides de sancts e sanctes", pel que cal esbrinar quins són aquests nous capítols. L’estructura no tancada de la $L A$-recordem que s’articula segons el calendari de les festivitats in circulum anni- permetria la inclusió de nous continguts en el cos del santoral; de fet, als manuscrits catalans més antics que contenen capítols nous respecte de la $L A$, per exemple les vides d'alguns sants locals, com santa Eulàlia de Barcelona o els sants gironins Narcís i Feliu, han estat inclosos en la data escaient de l'any litúrgic $3^{22}$ en canvi, és una tendència que variarà una mica amb l'arribada de la impremta, i de fet, ja als incunables observem que determinats continguts nous apareixen la fi, com s'esdevé amb les vides de santa Praxedis de Mallorca, sant Bernardí o santa Caterina de Siena (Càmara 2OI3: LI). Sembla que, en general, els impressors es mostren més conservadors amb el material anterior, i es limiten a enriquir la compilació acreixent-la per la part final. Aquesta serà una particularitat habitual en els santorals hispànics del Renaixement, i als nous capítols que s'afegiran a la fi, ubicats fora de la data de celebració corresponent, es referiran en moltes compilacions com a sants extravagants, és a dir, indicant que apareixen fora del lloc que els pertany.

Comprovem que en ${ }^{24}$ els cinc nous capítols s'han afegit a la fi del santoral, sense alterar el gruix de la compilació; són els dedicats a sant Sever de Barcelona, bisbe i màrtir; a santa Madrona, màrtir de Montjuïc; a sant Segimon, fill de rei de Borgonya; a santa Anna i a l’Àngel Custodi. Recordem que una inèrcia constant en l'evolució del santoral en romanç serà la d'acostar el llegendari a la geografia i l'espiritualitat dels devots a qui s'adreça, pel que no sobta que la totalitat d'aquests nous capítols responguen a devocions bastant arrelades al territori, en concret a l’àrea de Barcelona i zones properes.

Sant Sever i santa Madrona eren dos màrtirs de Barcelona molt venerats; Sever, un dels primers bisbes de la diòcesi, era, de fet, un dels patrons de la ciutat, les despulles del qual es custodiaven des de començament del segle Xv a la Seu per manament exprés del rei Martí l’Humà. ${ }^{33}$ Santa Madrona,

3. Vid. a López Casas (I998 i I999) l'edició completa i l’anàlisi d’aquestes dues epístoles, i a Ferrer (20Io) les consideracions sobre les amplificacions de la traducció catalana.

32. Vegeu una descripció dels manuscrits catalans de la $L A$, amb els afegits que incorpora cada cas, a Garcia Sempere $(2015)$.

33. Els testimonis arquitectònics de la ciutat també evidencien la vigència del culte al sant bisbe. Del segle XV data la construcció del Portal de sant Sever en la muralla, com també la fundació de l’Hospital de sant Sever; el I55O el Consell de Cent acordà col-locar una imatge del bisbe a la façana gòtica de la Casa de la Ciutat (juntament amb una de santa 
verge i màrtir de Montjuïc, també comptava amb un culte molt estés a l'època, que culminà només unes dècades després, quan en I564 el Consell de Cent decidí també fer-la copatrona de la ciutat. Santa Madrona, a més, era considerada protectora dels navegants, els quals li professaven una particular devoció. ${ }^{34}$ També des de finals de l'edat mitjana hi havia una especial devoció a la ciutat per l'Àngel Custodi, considerat un altre dels protectors de la vila. L'origen del culte es remuntaria a una visita que, a finals del segle XIV, féu sant Vicent Ferrer a la ciutat comtal. Quan aquest travessava l'aleshores conegut com a Portal dels Orbs de les muralles, albirà que a sobre hi era l'Àngel Custodi, qui l'informà que protegia la ciutat. Per rememorar aquesta visió, i recordar l'especial protecció de què gaudia la ciutat, a mitjans segle XV al portal es construí una capella amb una imatge de l'àngel, i el portal passà a ser conegut com a Portal de l'Àngel. Així mateix, sant Segimon, fill del rei de Borgonya, era molt venerat a la zona de Vic, ja que hi havia la creença que havia estat eremita penitent a una cova del Montseny, on, de fet, des del segle XIII hi ha un santuari que recorda la seua estada a la muntanya i dóna testimoni de la devoció arrelada a la zona. Sant Segimon, a més, era considerat protector contra la febre, i el missal de la diòcesi de Barcelona de finals del XV -reformat després de Trento-, incloïa la celebració de misses votives com la que s'oferia a sant Segimon en favor dels malalts de febre, que esdevingueren molt populars (Gelabertó 2003: 306, 308). El culte a santa Anna, a diferència dels casos anteriors, no és exclusiu de la zona catalana, perquè cresqué de manera notable des de finals del segle XV i al llarg del XVI a tota la Península; evidència de la vigència d'aquest culte són les diverses vides exemptes que s’imprimiren des de les darreries del segle XV i al llarg del Cinccents. ${ }^{35}$

Si bé la causa que explicaria la inclusió d’aquests capítols sembla ser la mateixa-l’interés que els nous capítols podien suscitar en els devots-, en canvi, la procedència dels textos sembla ser ben dispar.

Els relats dedicats a Sever, Madrona, i Segimon semblen ser hagiografies que circulaven exemptes. Tots tres relats, a més, tenen la particularitat de reproduir la versió més llegendària -i popular- d'aquestes hagiografies, i de fet, totes tres foren profundament revisades i esmenades en les compilacions hagiogràfiques postridentines.

La versió de la vida de sant Sever que s'arreplega a I ${ }^{24}$ (ff. CCLXV'a - CCLXVI ${ }^{a}$ ) és en realitat una barreja de les vides de dos bisbes sants de nom Sever: el bisbe Sever de Barcelona i el bisbe Sever de Ravenna. En realitat, el gruix principal del relat correspon a la vida del bisbe italià, d'ofici teixidor i elegit bisbe per designació divina, tot i que la història ha estat traslladada a la diòcesi de Barcelona, amb les incongruències argumentals que això comporta en el relat. Només el martiri final, per perforació del cap amb un clau, i el miracle final, obrat sobre el rei Martí l'Humà, corresponen en

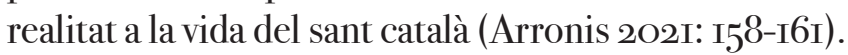

També la vida de santa Madrona reprodueix notícies llegendàries, com ara que fóra "natural de la dita montanya de Montjuïch”, particularitat que s'aprofita en el relat per justificar el retorn de les despulles de la santa al lloc "on era nada” per designi diví, ja que "no volgués nostre Senyor que

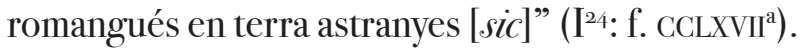

Eulàlia i l'àngel Rafael, altres protectors de la ciutat). Vid. en Arronis (2O2I) una anàlisi sobre el culte a sant Sever de Barcelona en la primera modernitat a través d'algunes hagiografies conservades.

34. Sobre el culte a santa Madrona en la zona de Barcelona, vid. Farías (20I7: 7 I-77).

35. Especialment difosa fou, per exemple, la Vida y excelencias y miraglos de santa Anna y de la gloriosa nuestra señora santa María fasta la edad de quatorze años, atribuïda a Juan de Robles, canonge de Sant Isidor de Lleó, impresa per primera vegada a Sevilla en I5II, i reeditada en nombroses ocasions al llarg de la centúria en diverses localitzacions (Toledo, Salamanca, Burgos, etc.). De fet, precisament la traducció fidel dels dos primers capítols d’aquesta vida s’inclogueren en la part dedicada a sants extravagants en el Flos sanctõrum em lingoajem português, imprés en Lisboa en I5I3 per Hermão de Campos i Roberte Rabelo (ff. CCLVIII'-. CCLXIII ${ }^{\mathrm{d}}$ ) (Sobral 2OO2: 540). 
La vida de sant Segimon destaca d'entre la resta dels capítols afegits tant per l'extensió que ocupa, com, sobretot, per la qualitat narrativa del relat, molt més acurat i ric en descripcions que la resta d’hagiografies. Una altra versió d'aquesta mateixa vida ja la trobem inclosa en un dels manuscrits catalans de la $L A$, el testimoni conservat a la l'Arxiu Capitular de Vic (sig. c. 174 L), editat per Rebull (I976: 9I2-I9). El relat és el mateix, però l'acarament dels dos textos permet apreciar la qualitat literària de la versió arreplegada a $\mathrm{I}^{24}$, amb constants amplificacions de caràcter emotiu, especialment en les intervencions en estil directe dels protagonistes:

\begin{tabular}{|c|c|}
\hline $\begin{array}{l}\text { LA:manuscrit Vic } \\
\text { "De la vida de sent Sagimon" }\end{array}$ & $\begin{array}{c}\mathbf{I}^{24} \\
{\left[\mathrm{I}_{5} \mathbf{5}\right] \text { "La vida de sant Sagimon qui fonch fill }} \\
\text { del rey de Burgunya" }\end{array}$ \\
\hline $\begin{array}{l}\text { E, a cap de temps, vengué lo rey de Burgunya, } \\
\text { son pare, gran desig e anyorament e a sa } \\
\text { mare, axí mateix, de veura sent Sagimon, lur } \\
\text { fill, dient la regina al rey: "Senyor e marit } \\
\text { meu, ¿e què farem de nòstron fill, que tant de } \\
\text { temps ha que no·n sabem res? Car, despulls } \\
\text { que hich partí nova naguna ne senyal no·n } \\
\text { avem. (...)”. (Rebull ed. } 1976: 9 \mathrm{I} 4 \text { ) }\end{array}$ & $\begin{array}{l}\text { Quant lo pare y la mare del gloriós sanct } \\
\text { Sagimon hagueren stat gran temps sens } \\
\text { veure'l ni saber res d'ell, hagueren desig molt } \\
\text { gran y natural de veure lur fill, e axí la reyna, } \\
\text { perquè era dona y son de major compassió e } \\
\text { amor prompte, del rey semblants paraules: }{ }^{6} \\
\text { "Senyor, quin oblit és stat aquest nostre, que } \\
\text { per no tenir sinó un sol fill, e aquell tant } \\
\text { virtuós, és stada tant pocha la ànsia vostra e } \\
\text { mia que tant temps ha passat sens conèixer la } \\
\text { soledat sua, ni fer-lo cerquar?" (f. [Io]") }\end{array}$ \\
\hline
\end{tabular}

Sembla, doncs, que el text havia estat difos a la zona de Vic per promocionar el culte al sant $\mathrm{i}$ promoure la visita al santuari; de fet, a la fi de la història s'especifiquen les gràcies i indulgències que hom aconseguirà visitant "la sua santa cel·la" (f. CCLXIX). Precisament, bona part del relat es dedica a narrar l'arribada i l'estada del sant eremita a una cova del Montseny, tradició apòcrifa que sembla ser d'origen llegendari. De fet, els hagiògrafs contrareformistes es doldran del silenci de les fonts. ${ }^{37}$

"La vida de la benaventurada santa Anna, mare de la gloriosa verge Maria" també podria haver estat presa de la Leyenda de los santos castellana en l'edició estampada per Juan Varela a Sevilla en I520-2I, és a dir, l'edició de la Leyenda de la que també semblen haver estat presos els preliminars del cicle de la Passió..$^{3} \mathrm{~A}$ aquesta edició de la Leyenda es declara que, precisament, aquesta vida és una de les novetats que s'hi incorporen, pel que sembla raonable considerar que també la vida de santa Anna haguera estat presa d'aquesta mateixa edició. Amb tot, el capítol ja apareixia en el santoral castellà conegut com a Flos sanctorum renacentista, que s'estampà per primera vegada a

36. Sembla que el verb del sintagma ha estat omés en la impressió.

37. Per exemple, el dominic Antoni Vicenç Domènec, en la seua Historia general de los santos... admetrà que l'únic argument per provar aquesta devoció a la zona és, precisament, la tradició secular del culte: "La venida de san Sigismundo a España no la escriven San Gregorio Turonense, ni san Antonino, ni otros historiadores franceses o de otras naciones. Pero tampoco no lo niegan, y assí no ay que dudar de una tradición tan grande como tenemos desto" (Domènec I602, I: f. $3^{8 \text { r). }}$

38. A la fi de la compilació s’afegeix una nova secció de sants extravagants que diu "Comiençan ciertas vidas de santos añadidas, que hasta aquí no estaban en el Flos sanctorum” (Cabasés 2007: 829); a continuació de la vida de santa Anna, s’inclouen altres capítols dedicats a personatges també vinculats amb la Mare de Déu, com una vida de sant Josep, o el capítol de la Visitació a santa Elisabet, i d’altres episodis dedicats a devocions pròpiament castellanes, com la vida del sant burgalés Juan de Ortega, o una història pietosa relacionada amb el rei Alfons IX. 
Saragossa, per Jorge Cocci, en I5I6.39 El text català n’és una traducció molt literal, ja que gairebé reprodueix la narració castellana paraula per paraula; a més, la presència de determinades lliçons difícils també en reafirmen la dependència (per exemple "debax de la dolçura", per traduir "debaxo de la dulçura"; "mon apareciment", per "mi aparecimiento"; o "girar la cara atrás", per "bolver la cara atrás”). El traductor, fins i tot, en alguns paràgrafs comet errades d'interpretació, pel que algunes de les oracions resultants tenen menys sentit que en el text original, o directament, manquen de sentit gramatical. Ho comprovem en el mateix començament del capítol:

\begin{tabular}{|c|c|}
\hline $\begin{array}{c}\text { Leyenda de los santos } 1520-21 \\
\text { "La hystoria de la bienaventura sancta Anna, } \\
\text { madre de nuestra Señora (...)" }\end{array}$ & $\begin{array}{c}\mathbf{I}^{24} \\
\text { [186] "La vida de la benaventurada santa } \\
\text { Anna, mare de la gloriosa verge Maria" }\end{array}$ \\
\hline $\begin{array}{l}\text { La vida de Joachim e de santa Anna, padres } \\
\text { de la gloriosa Virgen Madre del Salvador, } \\
\text { trasladó de hebreo en latín el bienaventurado } \\
\text { nuestro padre sant Hierónymo, a petición } \\
\text { e ruego de dos sanctos obispos que havían } \\
\text { nombre Cromacio y Heliodoro. Los quales } \\
\text { gelo enviaron a suplicar por su epístola } \\
\text { escriviéndole en esta manera: Señor muy } \\
\text { amado Hierónymo preste: fazemos saber a tu } \\
\text { caridad como en un unos libros apócriphos } \\
\text { hemos fallado el nacimiento de la Reyna del } \\
\text { cielo, nuestra señora sancta María, con el } \\
\text { tratado de la infância de Jesu Xristo. E viendo } \\
\text { que se contenían en esta escriptura muchas } \\
\text { cosas contrarias a nuestra santa fe cathólica, } \\
\text { paresciónos que era mejor de nos apartar } \\
\text { de todo en todo de la tal lección, que no, so } \\
\text { color de devoción, favorescer algún error. } \\
\text { (Cabasés ed. 2oo?: 829) }\end{array}$ & $\begin{array}{l}\text { La vida de Joachim e de sancta Anna, pare } \\
\text { e mare de la gloriosa verge Maria, mare del } \\
\text { Salvador, trelladat [sic] de hebraich en latí, lo } \\
\text { benaventurat nostre pare sant Hierònim, a } \\
\text { petició he pregràries de dos sancts bisbes } \\
\text { que havien nom Cromàcio e Heliodoro, los } \\
\text { quals ells los enviaren a suplicar per una } \\
\text { epístola, escrivint-los [sic] en aquesta manera: } \\
\text { Senyor molt amat Hierònim, te fem a saber } \\
\text { per caritat com en huns libres apòcriphos } \\
\text { havem trobat lo naciment de la Reyna del cel, } \\
\text { senyora nostra sancta Maria, ab un tractat } \\
\text { de la infância de Jesu Christ, senyor nostre. } \\
\text { E veent que se content [sic] en aquesta } \\
\text { escriptura moltas coses contràrias ha nostra } \\
\text { sancta fe cathòlica, semblà-nos que era millor } \\
\text { de apartar-nos de tot en tot de la tal liçó, que } \\
\text { no, sot color de devoció, favorir alguna error. } \\
\text { (f. ccciIII-d) }\end{array}$ \\
\hline
\end{tabular}

Un origen diferent sembla tenir el capítol de "La ystòria de la festa dels sancts àngels que nos guardan, que.s nomena l’àngel custodi”. El capítol no té res a veure amb la devoció existent a Barcelona per l’àngel protector i la llegenda que el vincula a la ciutat; en realitat sembla ser un sermó especulatiu de caire escolàstic en què s'exposen -entre d'altres qüestions- la naturalesa dels àngels i la seua funció; s’enumeren els profits que els fidels obtenen per la seua guarda o les raons per les quals se'ls ha de venerar, i cadascuna de les argumentacions es referma amb l'autoritat d'un versicle bíblic. El començament del capítol permet entreveure la funció primigènia de l'escrit, i suggereix que es tractava d'un sermó pronunciat amb motiu de la celebració de la festivitat de l’Àngel Custodi, el dos d'octubre: “Hoÿu germans molt amats, celebrem la festa dels sancts àngels que contínuament nos guarden, e dignament celebrem sa festa” (I24: f. CCLXXI $\left.{ }^{d}\right)$.

39. Els exemplars conservats de les primeres edicions d'aquesta compilació s'han conservat mutilats o incomplets (Comedic CMDCi79), raó per la qual el text corresponent al capítol de santa Anna, que apareix a l'índex de l'edició de Cocci de I5I6, no es pot llegir fins a l’edició sevillana de Cromberger de I540 (f. CCCXIIII'- ${ }^{\mathrm{a} C C X V}{ }^{\mathrm{c}}$ ); aquesta edició -i les successives-, permet corroborar que es tracta del mateix text que s'incloïa com a suposada novetat en la Leyenda de los santos de $152 \mathrm{O}-2 \mathrm{I}$. 
De tot el que s'ha exposat en l'anàlisi d'aquesta edició, poden extraure's algunes conclusions. Amorós, per a aquesta segona impressió del santoral, apostà decididament per la renovació dels continguts, tant per la part inicial, amb la inclusió d'uns preliminars de temàtica cristològica, molt preuats a l'època, com per la cloenda, amb la inclusió de diversos capítols d'interés per als lectors locals. Sembla, a més, que ho féu atret pel model de la Leyenda de los santos castellana, i en concret a partir de l'edició sevillana de Juan Varela de Salamanca de I52O, de la que prengué tant els preliminars, com un dels capítols afegits a la fi.

\subsection{L'edició fantasma de 1546}

Alguns estudiosos han apuntat la suposada existència d'una edició realitzada el I546, un testimoni de la qual es conservaria a la Biblioteca Lambert Mata de Ripoll, amb la signatura R.206.4 Tanmateix, en aquesta biblioteca només es custodia un únic exemplar, i és el corresponent a la primera edició de Carles Amorós, I ${ }^{\text {I9-2o }}$ (sig. R.456), ja tractada més amunt. En realitat, però, aquestes dues signatures remeten al mateix i únic exemplar de la biblioteca: l'actual és R.456, i l'antiga, que, fins i tot, encara figura al primer foli de l'exemplar, era R.206. No comptem tampoc amb cap notícia documental relacionada amb una suposada reedició del FS el I546, per la qual cosa cal concloure que es tracta d'una interpretació errònia de les dades sobre els testimonis conservats.

\subsection{La tercera, i última, edició del taller Amorós: 1547}

I ${ }^{47}$ seria, doncs, la tercera -i última- edició realitzada al taller dels Amorós.4 ${ }^{\text {II }}$ Aquesta edició se cita als catàlegs normalment amb el títol de Flor dels sants, però no perquè s'haja fet cap variació en el títol respecte de les edicions anteriors, sinó perquè el testimoni conservat el trobem enquadernat, a hores d'ara, amb la portada interior que en $\mathrm{I}^{24}$ obria pròpiament el santoral, i que també duia el títol Flor dels sants, sense cap al-lusió específica al contingut, ni a les novetats que incorporava, i amb l'idèntic gravat de la Mare de Déu de la Llet, i en el verso, el mateix del Judici Final. És evident, però, que aquesta portada, com en l'edició anterior, era la portada interna que, rere els preliminars dedicats a la Passió, obriria la compilació de vides de sants (on, precisament, falta el foli I), i que va ser relligada a l'inici del volum amb posterioritat, potser per suplir la carència de la portada original, perduda o deteriorada. D'una banda, costa de creure que no hi haguera, com en els casos anteriors, una portada més general on s'especificaren les novetats que incorporava aquesta nova edició, i de fet, a la "Taula de la present obra" que segueix la portada, sí que s’hi especifica que "entre les vides ho llegendes dels sancts y de les sanctes (...) n’i ha posades moltes de afegides ara novament estampades" (I ${ }^{47}:$ f. [ $\left.\left[2^{v}\right]\right)$. De l'altra banda, com ja he dit, el fet que, actualment, el primer quadern del santoral comence pel foli II ${ }^{\mathrm{r}}$, corrobora que aquesta fóra la ubicació primigènia d'aquesta portada.

L'edició, com s’indica en el colofó, fou feta “a despeses de Jaume Lacera, librater, ciutadà de Barcelona. Estampat en la insigne ciutat de Barcelona: per Carles Amoros: ciutadà de la dita ciutat: al primer de setembre. Any mil sinch cents y quaranta set" (I ${ }^{47}$ : f. [CCCXVIII $\left.{ }^{\mathrm{r}}\right]$. ${ }^{42}$ Han passat, per tant, més de vint anys des de l'edició anterior, però en les inèrcies de la impremta peninsular

4O. Vid., per exemple, Aragüés (2004: 5I9), que és seguit per Càmara (2OI3: XLI).

4I. Es conserva un exemplar incomplet a la Biblioteca Nacional de Catalunya (IO-VI-I7), al qual falten els folis 225232; vid. a BITECA (manid 2088) la descripció codicològica.

42. ambé en altres ocasions Lacera finançà altres edicions fetes per Amorós (Lamarca 20I5: 124). 
es pot comprovar que, sovint, en la dècada dels quaranta, els tallers consolidats, com el d'Amorós i hereus, en aquella època apostaven encara per títols consagrats del seu repertori, probablement perquè ja s'haurien esgotat els exemplars de tirades anteriors. ${ }^{43}$ No sabem si, a banda, altres factors conjunturals políticosocials i religiosos, com ara la celebració de les primeres sessions del Concili de Trento, pogueren haver avivat l'interés per la devoció als sants. Recordem, per exemple, que la sessió celebrada el I3 de gener del mateix I547, s'aprovava el decret de la Justificació, en el qual es refermava el valor de la fe juntament al de les bones obres, que, implícitament, reivindicava el valor del culte als sants com a models de vida exemplar. Potser aquest clima religiós ajude a explicar que, només un any després de l'edició d'I ${ }^{47}$, el text s'estampara novament (per Pere de Montpezat, com veurem en el següent apartat).

En aquesta edició del taller Amorós continuem veient les inèrcies que ja hem vist en les impressions anteriors: es pren molta cura dels aspectes formals, i veiem com continuen renovant-se determinats gravats procedents de l'edició incunable per altres nous de major qualitat, com ara el de sant Antoni abat (f. LI $)$. ${ }^{44}$ Malauradament, l'únic testimoni que conservem ha estat força mutilat precisament pels gravats, una gran quantitat dels quals han estat esgarrats.

$\mathbf{I}^{24}$

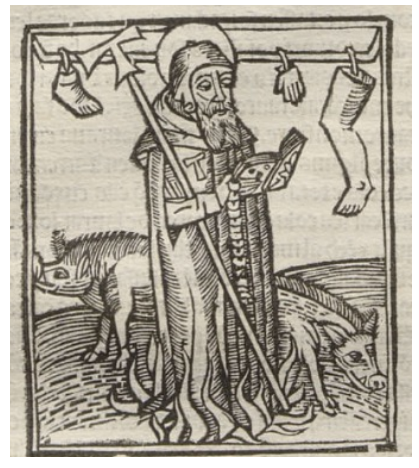

La vida de sanct Anthoni ([25]: f. XLIII)
I 47

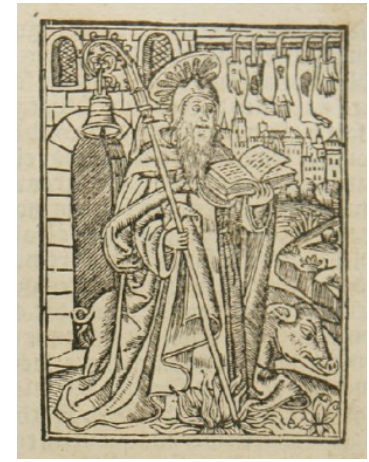

La vida de sanct Anthoni $\left([25] \text { : f. } \mathrm{LI}^{\mathrm{b}}\right)^{45}$

Pel que respecta al text, ${ }^{47}$ reprodueix amb força fidelitat el gruix de l'Inc. ${ }^{2}$, i encara arrossega moltes de les errades textuals presents en l'incunable. En canvi, i a diferència de les dues edicions anteriors d'Amorós, l'estructura sí que s'ha alterat una mica a conseqüència de l'omissió d'alguns capítols, i la incorporació d'altres de nous.

\subsection{Supressions i addicions de capítols}

Per primera vegada en les edicions cinccentistes, constatem que s'han suprimit fins a cinc capítols - pràcticament consecutius- respecte de les edicions precedents. Són els corresponents a la vida de la màrtir santa Susanna, que era un afegit de l'Inc. ${ }^{2}, \mathrm{i}$, per tant, no apareixia a la $L A$; "la història de Barlaam i com convertí el fill del rey Avenir", que és una versió cristianitzada de la llegenda de Buda; el capítol conegut com "la Dedicació de la Sglésia", que explica la simbologia del temple cristià; i els dos capítols que ja a les edicions incunables s'havien separat del capítol dedicat al papa Pelagi I

43. Per exemple, en I545 i en I548 al taller dels Amorós també s’estampà el Baculus clericalis de Bartomeu Cucala (impresa per primera vegada en $\mathrm{I}_{524}$ ),

44. En canvi, en el capítol de la Nativitat, ha recuperat el gravat d' ${ }^{19-20}$, que havia estat millorant per a l'edició d'I ${ }^{24}$, potser perquè la matriu s'havia deteriorat.

45. Les imatges d'I77 procedeixen dels fons de la Biblioteca de Catalunya (CCo). 
que inicialment els contenia, és a dir, el capítol dedicat a "la història de Mahomet", sobre la figura de Mahoma, i el capítol "Dels reis de França" que s'ocupa dels reis francs i dels emperadors del sacre imperi romanogermànic. El capítol dedicat al papa Pelagi, en canvi, sí que conservat, i de fet, es clou amb una al-lusió al contingut amb què originàriament prosseguia -ara omés-: "Y en aquest temps fon legida la història de Mahomet qui dir-se fehia propheta" (I ${ }^{47}$ : f. CCLXXXVIII $\left.{ }^{\mathrm{d}}\right) .^{46}$

Per intentar entendre la supressió d'aquests capítols, potser convé recordar que, amb l'excepció del cas de santa Susanna, que no apareixia en la $L A$, la resta de capítols-que apareixien rere les vides de sants eremites del desert- constituïen inicialment una sort de cloenda del santoral. Tal i com explica Maggioni,

Iacopo costituisce alla fine della Legenda aurea, in corrispondenza della conclusione dell'anno liturgico, una sorta di appendice senza alcun rapporto con il calendario (...) Iacopo però inserendo in successione cinque capitoli dedicati ai padri del deserto, il capitolo dedicato a Barlaam e Giosafat, la cosiddetta Historia Longobardica e, infine, il capitolo sulla Dedicatio ecclesie, costituisce una sorta di corpus organico che si integra coerentemente nel leggendario, facendolo terminare proprio nel luogo, spirituale o materiale, dove la storia e la geografia umana si annullano, con un itinerario finale, coronamento ideale dell'opera, che passa dal verbum (i cinque padri del deserto) all'exemplum (Barlaam) e alla storia umana (l'Historia Longobardica) ...Essendo facilmente rinvenibili nei codici a causa della loro collocazione, costituivano una sorta di prontuario a cui si poteva ricorrere per integrare con parole o esempi, con dati storici o ecclesiologici, ciascuna delle trattazioni particolari riguardanti gli altri capitoli (Maggioni ed. 2007: I705).

Potser, però, atés que en aquesta edició de cap manera es tractava de la conclusió de l'obra -ja que després de la vida del papa Pelagi encara s’hi comptem fins a tretze vides més com a consequiència dels successius afegits-, es va considerar que aquests capítols obstaculitzaven la coherència estructural del conjunt i que perdien la funció primigènia que posseïen. $\mathrm{O}$, potser, caldria pensar en altres hipòtesis de naturalesa diferent, més pràctiques i lligades a interessos comercials, com ara que es preferí substituir aquests episodis per altres que resultaren més atraients per al lector coetani, i evitar així allargar la compilació en excés. En darrer lloc, també podríem sospesar l'oportunitat o idoneïtat de determinats relats, com ara els dedicats a Barlaam, Mahoma o als reis de França, o fins i tot el de la Dedicació de l'Església, ja que no eren de temàtica estrictament hagiogràfica. ${ }^{47}$

Pel que fa als capítols afegits, són set les noves vides que s'hi incorporen. Dues s'han intercalat en el cos de la compilació: el capítol dedicat als sants màrtirs complutenses Just i Pastor ([84], f. CXLII $\left.{ }^{\text {a-d }}\right)$, i el capítol dedicat a sant Magí, copatró de Tarragona ([9I], ff. CLII- CLIII $\left.{ }^{\mathrm{c}}\right)$. Les altres cinc noves vides s'han inserit, com sol ser habitual en els impresos, a la fi del santoral, entre les altres cinc vides ja incorporades per ${ }^{24}$. Es tracta de les vides de sant Serapió; santa Escolàstica; sant Honorat, bisbe d'Arlés; sant Elm, patró dels navegants; i sant Bertrà.

Desconeixem la raó per la qual els capítols dedicats als sants infants d'Alcalà d'Henares i a l'eremita de la Brufaganya es van inserir en el cos de la compilació, i no, com havia esdevingut habitual en les edicions cinccentistes, a la fi del santoral. Potser es tractava de devocions particularment arrelades en el culte local i en els seus oficis. De fet, s'insereixen en la compilació

46. Segons explica Càmara, la presència del capítol dedicat a Pelagi I "es deu al fet que el seu pontificat coincideix amb l'inici del govern dels longobards a la península itàlica i, per tant, el començament de la cronologia que elabora Voragine" (20I3: IO33). Tal vegada aquesta és la causa per la qual és l’únic de la secció que no s’omet a I7. Vid. a l’annex la taula 2 de correspondències.

47. En particular, el capítol dedicat a Mahoma potser es considerava problemàtic. Recordem, per exemple, que als dos testimonis conservats d'I I ${ }^{\mathrm{I}} \mathrm{el}$ full que contenia aquest capítol sembla haver estat esgarrat. Vid. nota 7 . 
entre les festivitats dels mesos estivals, ja que els sants Just i Pastor se celebraven el 9 d'agost (vetus ordo), i sant Magí, el rg del mateix mes. Diferents evidències demostren la vigència d'aquestes devocions a la Barcelona tardomedieval i renaixentista. L’església gòtica dedicada als sants Just i Pastor es construí, precisament, entre els segles XIV i XVI, i probablement el culte per aquests infants màrtirs procedeix de més antic. La devoció a sant Magí tampoc no era exclusiva de la zona de Tarragona; notícies documentals del segle Xvı corroboren que també a la ciutat comtal era ben viva la devoció pel sant eremita. Sabem que en aquella centúria es fundà la primera confraria a la ciutat sota l'advocació de sant Magí, i que en diverses esglésies i convents de Barcelona, com ara en el convent dels Àngels, de monges dominiques, o en el monestir de Sant Pere de Puelles, de benedictines, es podia trobar aigua de la font de sant Magí, tinguda per miraculosa, per sanar malalts (Madurell I966: 2O-23)..$^{8}$

Els dos relats, a més, destaquen d'entre els capítols afegits per la seua qualitat literària. El capítol de Just i Pastor ha estat pres d'un santoral castellà, en aquesta ocasió del Flos sanctorum renacentista (o compilació A), el qual fou revisat i ampliat en dues ocasions (en I52I i en I54I) pel frare jerònim Pedro de la Vega, compilació que s’imprimí fins a disset ocasions al llarg de la centúria, moltes de les quals en dates molt pròximes a I ${ }^{47.49}$ Malgrat tractar-se d'una traducció molt literal del text castellà, la qualitat literària de la redacció no es veu reduïda, i fins i tot manté la vivacitat de les expressives intervencions dels personatges en estil directe:

\begin{tabular}{|c|c|}
\hline $\begin{array}{c}\text { FS de P. de la Vega } \\
\text { "Hystoria de los santos mártyres Justo y Pastor" } \\
\text { (Sevilla, J.Cromberger, I540) }{ }^{5 \circ}\end{array}$ & $\begin{array}{c}I^{4} 7 \\
{\left[8_{4}\right] \text { "La vida de sanct Just i sanct Pastor" }}\end{array}$ \\
\hline $\begin{array}{l}\text { El muy crudelíssimo Daciano, movido por } \\
\text { consejo del demonio, cercasse todo el mundo } \\
\text { desseando perseguir y matar los cristianos, o } \\
\text { los inclinar a offrecer sacrificio a los ýdolos, } \\
\text { allegose a la ciudad de Alcalá, que es en la } \\
\text { provincia de España, y halló ende dos niños } \\
\text { muy santos cristianos que havian nombre } \\
\text { Justo y Pastor. (f. CCCXXXIXa) }\end{array}$ & $\begin{array}{l}\text { Mentre que lo molt cruel Dacià, mogut per } \\
\text { consell del dimoni, cercava y escodrinyava } \\
\text { tot lo món desijant perseguir e matar los } \\
\text { chrestians, ho almenys conduir-los a sacrificar } \\
\text { y adorar les ýdoles, arribà a la ciutat de Alcalà, } \\
\text { que és en la província de Espanya, e trobà allí } \\
\text { dos minyons chrestians molt sancts que havia } \\
\text { nom la hu Just, y l'altre, Pastor. (f. CXLIII) }\end{array}$ \\
\hline
\end{tabular}

48. El jesuïta Pere Gil, per exemple, en les seues Vides de sants de Catalunya (I6oo ca.), a la fi del capítol que dedica a la vida de sant Magí, es fa ressò d’aquesta devoció a la ciutat, i explica: "En Barcelona y ha un monestir de monjas nomenat dels Àngels, en lo qual y ha una capella y altar de sant Magí, y las monjas del dit monestir acostuman entre any o casi tot lo any, tenir aygua guardada < de la font> de sant Magí per als malalts" (f. $17^{\vee}$ ).

49. Vid. Comedic (CMDCi79) i Aragüés (2005).

5o. Aquesta edició de Joan Cromberger de I540 és una reedició de la primera revisió feta per Pedro de la Vega en I52I (Saragossa, J. Cocci), la segona part del qual -on apareixeria aquest capítol- no s'ha conservat; d'altra banda, la revisió que Pedro de la Vega féu de la compilació en I54I (Saragossa, J. Cocci), manté el relat sense pràcticament variacions (f.CCCXVII ${ }^{\mathrm{c}-\mathrm{CCCXVIII}}{ }^{\mathrm{b}}$ ). És a dir, tota la tradició editorial d’aquesta compilació contenia el capítol dedicat als sants infants, per la qual cosa no és fâcil deduir de quina impressió va ser pres, potser d'alguna de les més properes en el temps (I54O, I54I, I544 O I545). 
(...) "Muy bien dizes, hermano Justo, porque assí te conviene seguir la justícia que demuestra y trae consigo tu nombre, y cosa deve ser a nosotros muy alegre poner nuestro cuerpo a muerte y derramar nuestra sangre por amor de nuestro Redemptor (...) e no nos deve embargar el amor de los parientes y amigos, ni la pequeñez de nuestra edad, mas corramos ligeramente a aquella claridad celestial" (f. CCCXXXIX)
(...) "Molt bé dius, germà meu, Just, e axí te convé seguir la justícia que te ensenya e ab si aporta lo teu nom, e per ço deu ésser a nosaltres cosa molt plasent liurar nostra sanch per amor de nostre Redemptor (...), y no·ns deu entristar ni detenir la amor dels parents e amichs, ni la poca edat nostra, mes corregam lleugerament y de bona gana en aquella claredat celestial" (f. CXLII $)$

Ben diferent és l'origen del relat de la vida de Sant Magí. Com ja va provar Arco (I9I5: 27374), l'hagiografia havia estat escrita pel canonge d'origen aragonés Joan de Sessé, al voltant de I529, encara que a I ${ }^{47}$ no consten aquestes dades.$^{51}$ En canvi, sí que es declara a la fi que la història comptava amb el vistiplau d'instàncies superiors: "fonch vista, legida y aprobada la present obra per lo reverent misser Francesch Juan de Maya, canonge official y vicari general per lo Senyor Arquebisbe de la Seu de Tarragona" (I ${ }^{47}:$ f. CLIII $\left.{ }^{\mathrm{c}}\right)$. El relat està escrit en una prosa que recorda la valenciana tardomedieval, i inclou nombroses anècdotes que de segur que atiaven la fe dels devots..$^{2}$

Els altres cinc nou capítols, com ja he avançat, sí que s’han introduït a la fi de la compilació, barrejats entre els que ja s'havien incorporat en l'edició anterior, i sembla que sense seguir cap tipus d'ordenació concreta. ${ }^{33}$ També en la majoria d'aquests casos podem suposar que la seua inclusió respon a l'interés dels devots coetanis. Entre aquests afegits, destaca, per la seua llargària -quasi quatre folis-, el de la vida de sant Elm, patró dels navegants, una advocació especialment viva aleshores en les poblacions marítimes, en moltes de les quals existien confraries de pescadors sota la seua advocació, com ara a l'antic barri de la Ribera de Barcelona. ${ }^{54}$ De fet, al títol s'explicita "advocat dels mariners, lo qual tostemps està prompte en lur ajuda" (I ${ }^{47}:$ f. CCCXIII ${ }^{c}$ ). Aquesta narració també sembla que haguera circulat de manera exempta, però no té la qualitat retòrica dels dos capítols comentats més amunt. A l’inici, l'autor es presenta, “frare Juan, prevere de Sanct Bertran, del mont de Barcelona”, i justifica l'interés pietós de la seua traducció: "la llegenda del gloriós màrtyr sanct Elm, axí com la devoció dels més devots la demanen, és de aquesta manera arromançada” (I ${ }^{47}$ : f. CCCXIII $\left.^{d}\right)$. Al relat s'expliquen amb detall els diferents episodis de turments i martiris que el sant

5I. Encara que en els prolegòmens del manuscrit original de la vida de sant Magí s’explicita l'autoria (Arco I9I5: 274), aquesta va ser omesa en l'edició de Carles Amorós (o en el text que prengué com a base), pel que el relat apareix com a anònim, i així continuà difonent-se en edicions posteriors, com en el FS de I575; d'aquesta última edició prengué el relat el dominic Vicenç Antoni Domènech i l'incorporà, també com a anònim, a la seua Historia de los santos y varones ilustres en Santidad del Principado de Cataluña (1602: ff. $\left.78^{\mathrm{v}}-8 \mathrm{O}^{\mathrm{r}}\right)$.

52. La prosa artitzada es pot apreciar en qualsevol passatge del relat: “Obehiren los servidors cruels al senyor més cruel, y exint per la mateixa porta, alguns d'ells moriren (...) com anyell mansuet, ab gran fúria prengueren y feriren-lo ab coces, galtades y naffres moltes, naffres sobre naffres ajustant, ara ferint lo cap, ara los braços, ara los peus" (I 47 : f. CLII $^{\mathrm{d}}$ ).

53. Així doncs, després del capítol de Caterina de Siena (f. CCXCVI ${ }^{b}$-últim capítol afegit pels incunables-, figuren les vides de sant Sever (f. CCCII ${ }^{b}$ ), santa Madrona (f. CCCIII ${ }^{\mathrm{c}}$ ), sant Segimon (f. CCCIIII ${ }^{\mathrm{d}}$ ), sant Serapió (f. CCCVIII ${ }^{\mathrm{a}}$ ), santa Anna (f. CCCVIII ${ }^{\mathrm{c}}$ ), santa Escolàstica (f. CCCX $)$, el capítol dedicat a l'Ầngel Custodi (f. $\mathrm{CCCXI}^{\mathrm{a}}$ ), la vida de sant Honorat, arquebisbe d'Arlés (f. CCCXIII ${ }^{\text {a }}$, la de sant Elm (f. CCCXIII ${ }^{\mathrm{c}}$ ) i la de sant Bertrà (f. CCCXVII $)$; vid. a l'annex la taula 2 de correspondències.

54. Al convent de Santa Clara del barri marítim de la Ribera de Barcelona, s'hi comptava des de l'edat mitjana amb una capella dedicada al sant. Amb posterioritat, el culte per sant Elm com a especial protector dels mariners en tota l'àrea mediterrània va decaure en favor de la devoció per sant Pere i per la Mare de Déu del Carme. Malgrat tot, s’ha mantingut vigent en algunes poblacions catalanes i mallorquines. 
suportà, i dels quals eixí indemne per la gràcia de Déu. En canvi, no s’hi inclou cap miracle. El capítol conclou reportant les notícies que el Martirologi romà arreplega sobre el sant, dades que semblen voler reforçar la legitimitat dels episodis explicats.

Els altres quatre capítols afegits són molt breus (una cara de foli, o menys), i semblen tenir una procedència heterogènia: bé d'altres compilacions que els contingueren, bé de relacions que circulaven de manera independent. També, com en el cas de sant Elm, en la rúbrica del capítol dedicat a sant Bertrà de Comenge s'explicita que s’ha inclòs “per prechs y devoció de alguns devots". La vida, però, es resumeix en poques línies, mentre que la resta del capítol es dedica a la narració de tres miracles atribuïts al sant. De fet, del sant bisbe s'hi destaca la seua capacitat taumatúrgica, i a la fi es declara que, de miracles, només se n’han copiat un pocs, explicant que "n’i ha molts escrits en aquesta església, y de aquell número que he trobats escrits, n’e trets ací alguns que m’a paregut ser més breus i plasents per als devots" (I ${ }^{47}$ : f. CCCXVII ${ }^{\mathrm{d}}$ ). No sabem l'església a la qual es refereix l'autor anònim, però atés que el relat anterior -de sant Elm- declara ser responsabilitat d'un prevere de l'església de sant Bertrà de Barcelona, podríem conjecturar si aquests breus apunts pogueren ser de la mateixa autoria.

També tenim constància de la devoció existent als segles XV i XVI en els territoris catalans i valencians per sant Honorat, bisbe d'Arlés, i en són prova diversos testimonis escrits que relaten l'hagiografia de l'eremita. De fet, un dels manuscrits del segle Xv de la $L A$ en català, conservat a l'Arxiu Capitular de Vic (c. I74 L), ja contenia un capítol dedicat a aquest sant (Garcia Sempere 20I5: I73), que, però, poc té a veure amb la versió d'I I7 .55 Comptem, així mateix, amb narracions llargues impreses de la seua vida (I495, I5I3 i I590), i cabria sumar altres versions rimades que circularen al Cinccents (Garcia Sempere 20I2b: 195).

Santa Escolàstica, germana de sant Benet, era considerada copatrona de Vic. Hi ha documentada la veneració d'una relíquia de la santa -un peu-, a la catedral de Vic des de finals del segle XV, encara que al capítol no se’n fa cap al·lusió. L’episodi és molt breu: es narra el darrer encontre que la santa mantingué amb sant Benet, esdevingut poc abans del seu traspàs, anècdota que, segons es declara al text, procedeix dels diàlegs de sant Gregori. Tanmateix, aquest succés ja apareix contingut en el capítol de sant Benet de la $L A$ ([48], Maggioni ed. 2007: 366), i en conseqüència, en els $F S$ en romanç, també en els catalans que ara analitzem. La peripècia que s'hi narra és exactament la mateixa, però en el capítol específic dedicat a Escolàstica que ara s’afegeix, se’ns dóna una mica més d'informació, com ara el nom de la santa, o referències a la seua suposada vida monàstica (dades silenciades en la $L A$, i per tant, en els FS), i s’acoloreix la narració amb petits detalls: 


\begin{tabular}{|c|c|}
\hline $\begin{array}{c}\text { I } 47 \\
\text { [52] "La vida de sanct Benet" }\end{array}$ & $\begin{array}{c}\text { I }{ }^{47} \\
\text { [185] "La vida de sancta Escolàstica" }\end{array}$ \\
\hline $\begin{array}{l}\text { Una vegada devallà sanct Benet del monestir } \\
\text { per visitar la sua sor, e axí com sehia a la taula, } \\
\text { ella lo pregà que romangués la nit ab ella, mes } \\
\text { ell no volgué consentir. } \\
\text { Per què ella, ab lo cap inclinat, pregà a Déu, } \\
\text { y vengueren tant grans trons e tanta pluja } \\
\text { que no pogué exir de sa casa, perquè ell fon } \\
\text { meravellat, y majorment que vehia que era } \\
\text { lo temps clar. E dix: “Déu te perdó, sor mia, } \\
\text { què és açò que has fet?”. Y ella respòs: “Jo’t } \\
\text { preguí que romanguesses e no me’n volgueres } \\
\text { obehir, mes yo he Déu pregat, e ham la per sua } \\
\text { pietat ohit. Ara hixte’n si pots”. Enaxí que tota } \\
\text { aquella nit vetlaren yS delitaren en parlar de } \\
\text { Déu (...) (f. cCCXXXIXa) }\end{array}$ & $\begin{array}{l}\text { Escolàstica verge, germana de sanct Benet, } \\
\text { fon de petita edat posada a monja, la qual } \\
\text { acostumava vestir [sic] a son germà una vegada } \\
\text { en l'any. Esdevench-se que un dia, essent anat } \\
\text { sanct Benet ab sos dexebles a veure-la, segons } \\
\text { que acostumava, y com haguessen passat tot } \\
\text { aquell dia ab sancta conversació, essent ja } \\
\text { tart, se posaren a sopar. Y estant sobre taula, } \\
\text { la sancta verge pregà a son germà li fes gràcia } \\
\text { de restar aquella nit allí, perquè ab sa divina } \\
\text { conversació prengués ella alguna refecció, lo } \\
\text { que ell molt negà. Y com en aquell punt lo cel } \\
\text { fos tant seré, que de nenguna part se mostrava } \\
\text { un petit núvol, la beneyta verge, ajuntant les } \\
\text { mans, abaxà lo cap sobre les mans, mostrant } \\
\text { voler pregar a Déu. Aquí mateix se mogué } \\
\text { tant gran impetut de lamps, trons y pluja, que } \\
\text { no sanct pare, ni los qui ab ell eren, gosaren } \\
\text { ni pogueren traure lo peu de casa. E axí, no } \\
\text { podent eixir del monestir, aquell qui pregat } \\
\text { y bonament no volgué restar, fonch forçat } \\
\text { encara que li pesàs, y tota aquella nit passaren } \\
\text { sens dormir, conversant y parlant tostemps de } \\
\text { coses de Déu (...) (f. cccx }{ }^{d} \text { ) }\end{array}$ \\
\hline
\end{tabular}

Sembla que l'impressor, motivat pel desig d'acréixer la compilació, i de reunir com més reclams possibles per al públic potencial, no parà esment en el fet que, en realitat, duplicava el contingut ja existent a la compilació.

En darrer lloc, mereix una reflexió una mica més detinguda el capítol dedicat a sant Serapió. El breu relat que s'hi incorpora narra el martiri de Serapió d'Alexandria, esdevingut al segle III ("Nasqué en Alexandria, ahon prengué lo martyri”, I I77: f. CCCVIII"). No he trobat cap evidència del seu culte a la zona, però atés que les altres vides incorporades com a novetats a ${ }^{47}$ semblen respondre a devocions existents, potser també aquesta ho fóra. Però ocorre que, en realitat, sí que tenim constància de la devoció per un altre sant del mateix nom: sant Serapió d’Alger, protomàrtir mercedari (s. XIII). Com és ben sabut, l'orde de la Mercé, fundada a Barcelona al segle XIII per Ramon Nolasc, adquirí un protagonisme destacat especialment en la primera modernitat per la seua dedicació a l'alliberament del captius presos en el Mediterrani. La presència de l'orde a la ciutat, al voltant del convent de la Mercé, era ben notòria a l'època, i per tant, també la devoció pels seus principals adalils, com Serapió, considerat, a més, protector dels malalts. Entre els dos sants Serapió, el de l'Alexandria i el d'Alger, cal destacar, a més, una coincidència més que curiosa: els dos comparteixen el mateix idèntic motiu de martiri: foren penjats a una creu i esquarterats, com representa el gravat que s'inclou a l'inici del capítol. $5^{6}$ En el cas del d'Alexandria, però, el martiri encara continua, ja que la narració explica que el rei manà que, després de ser esquarterat, en llançaren les restes de la torre. No sé si podria ser massa agosarat considerar que, en realitat,

56. Tal volta es deu a un cas de superposició de les vides dels dos sants, com per exemple, s’havia esdevingut amb el cas dels sants bisbes Sever de Ravenna i Sever de Barcelona (Arronis 202г: 157-58). 
s'introduí la vida d'aquest màrtir dels primers segles quan, en realitat, la devoció existent a la zona podria correspondre al sant mercedari. Les representacions iconogràfiques del martiris respectius -gairebé idèntics-, certament, no ajudaven a aclarir la qüestió sobre quin sant s'estava venerant.

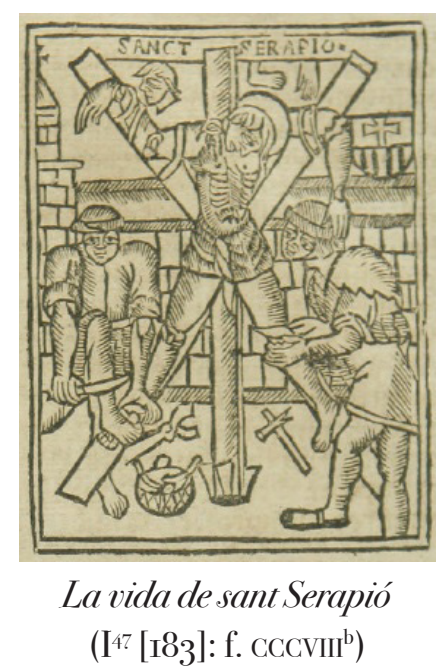

Les modificacions en el contingut que aplica Amorós en aquesta edició, suprimint capítols del corpus inicial, i afegint-ne d'altres, fins i tot en el bell mig del santoral, posen de manifest, una vegada més, que el santoral es percebia com una compilació oberta, al servei dels interessos devots dels seus lectors més immediats. D’altra banda, es comprova que, per segona ocasió, Carles Amorós coneixia diferents edicions dels santorals castellans, dels quals prenia els materials que considerava oportuns per introduir-los en la compilació catalana, com hem vist en el capítol de Just i Pastor. Òbviament, reunia materials de tot tipus de procedència, també hagiografies que circulaven exemptes, però fins ara gairebé no s'havia parat atenció a les possibles dependències existents entre aquestes tradicions editorials hispàniques dels flores sanctorum. Cal posar en valor, en el cas d'aquest impressor, l'afany que mostra per reunir textos que responien a les devocions vigents a l'època a la zona, ja que això ho hem pogut constatar tant en I ${ }^{24}$, com ara en I ${ }^{47}$.

\subsection{L'edició perduda de Pere Montpezat (1548-49), revisada per Esteve Ferrer}

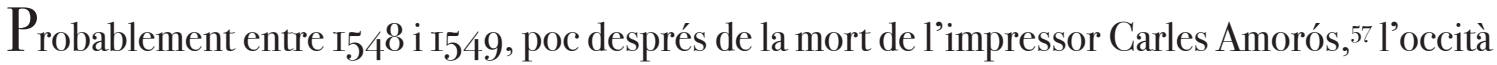
Pere de Montpezat, que havia estat un parell de dècades abans impressor del taller d'Amorós, ${ }^{5^{8}}$ prengué el testimoni i imprimí una nova edició del Flos sanctorum, de la qual sembla que no s’ha conservat cap exemplar. ${ }^{59}$ Comptem, però, amb la descripció que en féu Marià Aguiló (I923: 316, nº Io68). Segons la seua transcripció, al títol s'afirmava que aquest $F S$ havia estat corregit pel lector de la Seu, i que també hi incorporava novetats:

57. Sabem que Amorós féu testament en I548, i en I549 tenim documentada la seua muller com a vídua (Lamarca 2OI5: 44).

58. Per a Lamarca (20I5: 36) les col-laboracions de què es tenen notícia, evidenciarien la bona relació laboral existent entre els dos impressors.

59. Colomer (ı995: I25, nota Io) apunta, sense precisar massa dades, que un testimoni fragmentari que conserva la Biblioteca Borja de Sant Cugat del Vallés podria correspondre a aquesta edició. Tanmateix, al catàleg de la Biblioteca no apareix cap rastre d'aquest testimoni, ni els bibliotecaris actuals m’han pogut aportar més informació. 
nouament estampat: y ab molta diligència corregit per lo reuerent mestre Steue Ferrer, lector de la Seu de Barcelona: En que s’i són affegides diuerses vides de sancts y sanctes, les quals no són estades fins ací estampades. MDXLIX.

La succinta descripció d'Aguiló ens permet conjecturar, però, que reproduïa també la part inicial dedicada a la Passió, tradicionalment impresa sense numeració, ja que especifica: “269 hojas foliadas, y I2 al principio sin foliar”, pel que podem suposar la filiació amb les edicions anteriors d'Amorós.

També ens interessa el colofó (que, sempre segons la transcripció d’Aguiló, indica ara l'any I548), perquè la fórmula emprada és idèntica a la que reproduirà l'edició posterior de I575, impresa, precisament al taller de la viuda de Montpezat, Eulàlia, cosa que ens permet afirmar que aquesta edició també fou clau en la transmissió editorial successiva:

A llahor y glòria de nostre senyor Déu, y de la humil verge Maria mare sua y de la benauenturada sancta Eulària patrona nostra ${ }^{60}$ y dels gloriosos sancts y sanctes de Paradís, feneix lo present llibre anomenat Flos sanctorum: Nouament estampat en la insigne ciutat de Barcelona per Pere Montpezat estamper: A v de Noembre del any M.D.XLVIIJ. Deo gratias.

És la primera vegada en la tradició editorial del $F S$ català en què trobem dues edicions tan properes en el temps. Com ja he apuntat a l'apartat anterior, en ocupar-me d'I't7, els més de vint anys que havien trascorregut des de l'anterior edició d'Amorós, ${ }^{24}$, ens fan pensar en motivacions mercantils, ja que, probablement, els exemplars de tirades anteriors s'haurien exhaurit. D'altra banda, però, el context sociopolític i religiós d'aquells anys, amb la celebració de les primeres sessions tridentines, i la controvèrsia luterana contra el paper d'intercessors dels sants en el seu punt més àlgid (Baños 20I9), probablement reviscolà l'interés per la matèria entre els catòlics, i afavorí la impressió de noves edicions. ${ }^{6 \mathrm{r}}$

\subsection{L'edició de 1575, de la viuda Montpesaza i Jaume Cendrat, revisada per Pere Coll}

Abans d'ocupar-nos de l'última edició del santoral medieval que aparegué en català a les premses, convé parar esment a la particular cruillla sociocultural i religiosa en què es publicà, i que explicaria tant la seua impressió com alguns dels trets que presenta, i que la singularitzen. Des de l'anterior edició de Pere de Montpezat, feta entre I548-49, havien passat més de vint-i-cinc anys, i en aquest període, el clima religiós, pel que fa al culte i la devoció al sants, era sensiblement diferent, ja que ens trobem en els anys immediatament posteriors a la clausura del Concili de Trento.

En la darrera sessió del Concili, la XXV, celebrada el 3 i 4 de desembre de I563, sobre "la invocació, veneració de les relíquies dels sants i sobre les sagrades imatges", s'havia refermat la validesa del culte als sants en l’Església catòlica. Es posava així en valor la devoció als sants com a mitjancers per aconseguir la gràcia divina, recordant, però, que era només Déu qui la dispensava; se subratllava el valor exemplar que es desprenia de les seues vides, i el profit que es derivava del culte a les relíquies i a les imatges, que reforçaven la fe del devots. Es ratificava, per tant, la tradició

6o. L'esment a la patrona de Barcelona, santa Eulàlia, sembla, a més, especialment pertinent pel fet que era el nom de la muller de Pere de Montpezat, i potser hi professaven una devoció particular. També cal notar que Esteve Ferrer, el lector de la Seu de Barcelona que hauria revisat l'obra, segons notícies de Torres Amat (I836: 24I), també en I549 escrigué una Vida de santa Eulàlia de Barcelona.

6I. Recordem també que en el context castellà, només en la dècada dels quaranta, es feren cinc edicions del Flos sanctorum renacentista (Comedic CMDCi79). 
de venerar els sants, un fervor que es vindicava ara, a més, con un dels fets diferencials de l'esperit catòlic en front de l'heretgia luterana. Però a més de reforçar l'aspecte dogmàtic i doctrinal enfront de les controvèrsies del moment, s'anà concretant la tasca reformadora que s'havia d'escometre en els aspectes més pràctics vinculats a la seua devoció.

I és que en la controvèrsia sobre el culte als sants sostinguda entre catòlics i luterans, a més de qüestions dogmàtiques, també s'havien exposat polèmiques relacionades amb la qualitat dels escrits devots, en particular en relació a la problemàtica del contingut apòcrif i poc provat present en els textos hagiogràfics. Era una qüestió que havia estat denunciada fins i tot per molts teòlegs catòlics reformistes des de l'inici de segle, però sens dubte, l'escarni que els luterans feren de l'escassa qualitat dels escrits hagiogràfics, esperonà la tasca dels catòlics per dur a terme una revisió definitiva. ${ }^{62}$ El rerefons d'aquesta controvèrsia resulta clau per entendre les principals línies d'actuació dels hagiògrafs catòlics de la segona meitat del Cinccents arreu de l'Europa catòlica: ho comprovem, per exemple, en la publicació del santoral reformat de Lluís Lippomano, bisbe de Verona (I55I-60). ${ }^{63}$ Aquesta compilació encarnava l'esperit tridentí: tenia una clara pretensió contestatària, latent rere l'objectiu de recuperar l'autenticitat dels textos hagiogràfics, eliminant tot allò que es considerava apòcrif, és a dir, allò escrit per autors desconeguts o que tenia una procedència incerta. Per a la consecució d'aquest objectiu, Lippomano explicitava en el pròleg la necessitat de recórrer exclusivament a fonts antigues -com més millor-i reconegudes, és a dir, a escriptors il.lustres acceptats per tothom, fins i tot pels mateixos heretges, per evitar que feren burla dels escrits catòlics (Baños 202O: 442).

En el Concili de Trento no es dugué a terme la revisió dels escrits litúrgics i paralitúrgics, però s'establiren les bases i les directrius sobre com escometre aquesta tasca, i es va encarregar a la Seu

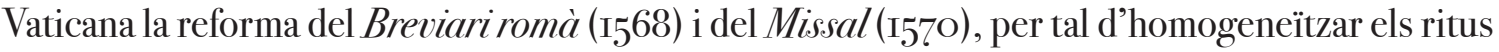
dels catòlics, suprimir determinades pràctiques tingudes per heterodoxes, i revisar els textos tocants a les llegendes dels sants. Prompte veren la llum altres obres complementàries que responien a la mateixa intenció de depurar els escrits de la tradició: com ara l'edició del Martirologi d'Usuard revisat per Johannes Molanus (I568), del Martirologi romà “oficial” de Cesare Baronius (I584) o la publicació completa del De probatis sanctorum historïs del cartoixà alemany Llorenç Surio (I57O75), veritable pedra de toc de l'hagiografia reformada postridentina. ${ }^{64}$

Des de Trento, però, també s’apel.là a la responsabilitat pastoral, particularment dels arquebisbes i bisbes, per vetlar pel correcte adoctrinament dels fidels en cada diòcesi, i per l'aplicació de les directrius del Concili. Així, els decrets tridentins foren promulgats en Catalunya en el Concili Provincial Tarraconense de 1564-65, convocat per l'arquebisbe Ferran de Loaces. En la diòcesi de Barcelona, el bisbe Guillem Cassador convocà el Sínode de Barcelona el 6 d'abril de I566, després del qual es va encomanar als deans i rectors de les parròquies que penjaren cartells en les portes de les esglésies anunciant la promulgació dels decrets tridentins. Pocs anys després, en I573, el nou arquebisbe de Tarragona, Gaspar Cervantes -que havia participat en el Concili-, ordenà publicar en català l'obra Instruccions y advertiments molt útils y necessaris per a les persones eclesiàstiques y principalment per als qui tenen cura de ànimes, per tal de difondre l'esperit tridentí entre els eclesiàstics (la segona edició de la qual feren, precisament, Jaume Cendrat i Eulàlia

62. Sobre la qüestió, vegeu Baños (2Or9 i 2020).

63. Sanctorum priscorum patrum vitae, numero centum sexagintatres, per gravissimos et probatissimos auctores conscriptae, 8 vols, I55 I-60. Vid. una caracterització de la compilació a Boesch-Gajano (I990).

64. Surio prengué com a punt de partida la compilació del bisbe Lluís de Lippomano, que completà i revisà; el cartoixà alemany no fou tan restrictiu en l'ús de les fonts com el seu predecessor, i millorà l'organització del compendi atenint-se al Breviari romà promulgat per Pius V. La compilació de Surio esdevingué el model de referència per als hagiògrafs posterios (Baños 2020: 444-45). 
de Montpezat també en I575). En algunes diòcesis, com en la de Barcelona, i amb la intenció d'implementar les reformes tridentines amb celeritat, se celebraren sínodes sovint, i en determinats períodes, fins i tot anualment, com ara entre els anys I57O-75 (Betrán 20i8: 196-97).

En aquest clima d'enaltiment de les senyes d'identitat catòlica i de concreció dels decrets tridentins, els impressors Cendrat i Montpezada, probablement, albiraren l'oportunitat de traure al mercat una nova edició d'aquell text bandejat de les premses des de feia vint-i-cinc anys, precisament motivats pel valor que la tradició li confegia. De fet, en la llicència d'impressió concedida a Jaume Cendrat, signada pel lloctinent de Felip II, Ferran de Toledo, se subratllava, entre altres valors, que era una obra, que havia estat traduïda al català des d'antic (Madurell I955: 380):

nos és grat deduyr que haveu fet regonèxer, corregir y aprovar per lo venerat y devot religiós (...) fray Pedro Coll, doctor en Sacra Theologia y prior del monestir y convent de santa Caterina de Sena (...) lo libre anomenat Flors sanctorum en llengua catalana, de molt temps ensà compost, y de nou affegides les vides de sanct Yvo, sant Francisco de Paula, sanct Basílio, sancta Otília y la Passió dels deu milia màrtirs, suplicant-nos que, atés y considerat lo treball y gasto que per açò haveu posat, fóssem servit de donar-vos licència de poder imprimir aquell (...) per algun spay de temps y que ninguna persona (...) lo puga stampar ni vendre sens vostre consentiment (...) pugeu fer stampar y vendre lo dit libre Flos sanctorum ab les vides dels sants que de nou hi haveu afegides (...) per spay de deu anys (ACA, Reg. $n^{\circ}$ 4702, f. $267^{r}$ )

Però com veiem, no és l'únic valor que s'hi destaca: també es posa en relleu el fet que el santoral haja estat revisat i esmenat pel doctor en teologia Pere Coll, prior del convent de santa Caterina de Barcelona. Sembla que els editors, conscients del nou i singular context doctrinal en què s'emmarca la impressió, procuraren que una autoritat de renom a la ciutat revisara el text. I si, certament, aquest testimoni està lluny de ser un santoral reformat postridentí -perquè continua sent, en essència, la reedició d'un text de procedència medieval amb afegits cinccentistes d'índole molt diversa-, una anàlisi minuciosa ens permet comprovar que sí que hi ha hagut algunes intervencions sobre el text que obeeixen a les principals directrius postridentines pel que fa a la revisió de la matèria hagiogràfica, orientades especialment a adequar el contingut als criteris d'autoritat que exigia l'Església, per la qual cosa quasi podríem qualificar-lo de santoral de transició ${ }^{65}$

Convé advertir que, malgrat que a hores d'ara no comptem amb cap exemplar d' ${ }^{44^{8-49}}$, sembla plausible afirmar que I75 prenguera com a base textual l'edició de Pere Montpezat per dues raons fonamentals: en primer lloc, perquè una de les responsables de l'edició de I575 és, precisament, la viuda de Montpezat, Eulàlia -que continuà amb l'activitat del taller a la mort de l'impressor-; ${ }^{.6} \mathrm{i}$ en segon lloc, perquè, com ja he esmentat en l'apartat anterior, la fórmula usada en els colofons de totes dues edicions és quasi idèntica:

A llaor y glòria de nostre Senyor Déu y de la gloriosa verge Maria mare sua, y de la benaventurada sancta Eulària, patrona nostra, y dels gloriosos sancts y sanctes de Paradís, feneix lo present llibre

65. També en el context portugués immediatament postridentí, es dugué a terme la revisió del llegendari medieval. L'arquebisbe de Braga, el dominic Bartolomeu dos Mártires, que havia participat en el Concili de Trento, i havia contribuït a l'aprovació dels decrets sobre la veneració de les imatges dels sants, encomanà al també dominic Diogo do Rosário la revisió del santoral. Així es publicà la Historia das vidas e feitos heroicos e obras insignes dos sanctos: cum muitos sermões \& praticas spirituaes, que servem a muitas festes do anno (Braga, ${ }_{5} 67$ ), que conegué un ressenyable èxit a les premses (I577, I590, I622, I647, I68I). Sobre les particularitats d'aquest santoral, vid. Sobral (2OI7).

66. Sobre l'activitat impressora d'Eulàlia de Montpezat, activa a Barcelona entre I57o i I576, vegeu Establés (20I8: 26o-6I), encara que no fa cap esment de l'edició d'aquest santoral. 
anomenat Flos sanctorum, novament estampat en la insigne ciutat de Barcelona en casa de Jaume Sendrat y la viuda Montpesada, any MVLXXV (I 75 : f. CCIX $v)^{6 z}$

Malauradament, no conéixer les particularitats de l'edició que Pere Montpezat enllestí en I54849, ni el tipus de correcció que hi aplicà el lector de la Seu, Esteve Ferrer-segons es declarava al títol-, impedeix afirmar amb plena certesa quines modificacions de les que presenta I ${ }^{75}$ són exclusives d'aquesta edició, i quines ja eren presents a l'edició anterior. No obstant això, la majoria de les intervencions que s'observen en I ${ }^{75}$ podrien ser genuïnes d'aquesta edició, ja que semblen correspondre a una sensibilitat postridentina i a la voluntat de revisar i adequar la matèria hagiogràfica. Podem identificar, almenys, tres línies d'intervenció sobre el text que s'alineen amb aquesta intenció: s'ha afegit un pròleg introductori de sensibilitat marcadament contrareformista; s'ha examinat el text parant atenció a la presència de passatges apòcrifs; i s'ha procurat millorar el caràcter doctrinal d'alguns episodis recolzant els continguts amb veus d'autoritat o amb versicles bíblics. A més, l'estructura del santoral sembla que ha estat revisada per evitar duplicitats i per millorar l'ordenació d'alguns continguts. I a aquestes intervencions aplicades sobre el text, cal sumar aquelles modificacions resultants de les inèrcies editorials ja consolidades al llarg de la centúria, com ara el fet de continuar renovant els continguts del corpus originari de Voràgine amb capítols nous. Per totes aquestes raons, convé exposar breument els trets que particularitzen aquesta edició, i no comptar-la com una més de les que s’havien anant succeint a les premses en la primera meitat del segle.

\subsection{Nous capítols, omissions i canvis estructurals}

L'únic testimoni conegut a hores d'ara d'I ${ }^{75}$ no posseeix portada original, sinó que s'ha copiat a mà, i sembla que parcialment, la informació que hi devia aparéixer: ${ }^{68}$

Flos sanctorum. Traducció feta del llatí al català del que escrigué lo reverent doctor mestre Joan Jerson, molt digne canceller de la ciutat de París. Dedicat a la santíssima mort y Passió del Redemptor Nostre Jesús. Estampat en la ciutat de Barcelona en casa de Jaume Cendrat y la viuda de Monpesada, any MCLXXV.

Dorca (I796: 204), que consultà un exemplar amb portada, transcriví el títol complet que hi apareixia, i que seria el següent:

Flos sanctorum compilat en llatí per lo il-lustre y reverendíssim Senyor don Jaume de Voràgine, bisbe de Gènova, y traduït de llatí en romans per Joan Jerson canceller de París, y ara de nou corregit y emendat per lo reverent Pere Coll, mestre en Sacra Teologia y prior de Sancta Catherina de la present ciutat, y ajustades ara de nou moltes vides de sancts y sanctes. Estampat en Barcelona en casa de Jaume Sendrat y la viuda de Monpesada, any MCLXXV. ${ }^{69}$

67. Vid. supra la transcripció del colofó d'I [4-49 $^{8-}$.

68. El testimoni es conserva a la Biblioteca Nacional d'Espanya (R/I2IO4); vid. la descripció a BITECA (manid 2089), encara que cal advertir que, erròniament, s'hi indica com a data de publicació ${ }_{57} 6$. Tant al colofó de l'exemplar, com a la resta de notícies històriques amb què comptem (com la llicència), s’hi explicita sempre l'any I575. Al santoral, li manca un foli (el que correspondria al f. LXXXXIV), que sembla haver estat esgarrat, on probablement apareixerien les vides de santa Marina i santa Margarida.

69. Torres Amat (I836: I83) dóna notícia d’una edició que s’hauria realitzat en casa de Jaume Cendrat en I565, i que hauria estat revisada pel dominic Pere Coll, prior de Santa Caterina de Barcelona, conservat encara en la biblioteca d'aquell convent (edició que assumeix com a vàlida Courcelles I99O: I9). Tanmateix, considere que Amat s'està referint a aquesta edició de I575, ja que el títol que aporta és idèntic al que dóna Dorca (I796: I53, 204) i tots dos es refereixen a 
Com en la llicència, s'hi fa esment de la revisió escomesa per Pere Coll, i s'hi al-ludeix als nous capítols afegits. Tanmateix, sabem que la informació apuntada sobre la traducció feta per Gerson hauria de referir-se exclusivament a la part inicial de l'obra, la dedicada a la Passió, i no al conjunt del santoral, per la qual cosa, potser, la transcripció no siga completa, o si ho és, la informació no seria exacta.

L'edició no té la qualitat de les impressions anteriors del taller d'Amorós que hem estat analitzant. Moltes caplletres miniades i orles decoratives amb motius naturals s'han eliminat o substituït per altres més senzilles. El mateix ha ocorregut amb els gravats. Alguns, no gaire, han estat substituïts per altres de tècnica més refinada; es tracta principalment d'aquells que tenen a veure amb episodis de la vida de Jesucrist i de Maria, amb els evangelistes i els principals deixebles; la gran majoria, en canvi, són imitacions molt rústegues de les xilografies anteriors:

I 47

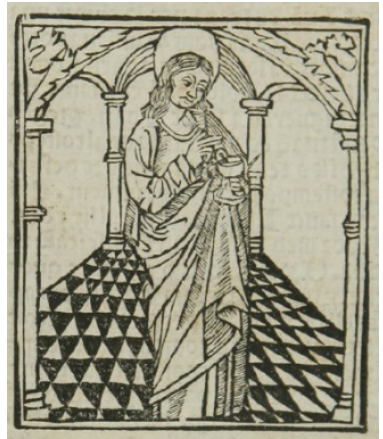

La vida de sanct Juan apòstol y evangelista ([II]: f. XXVI')

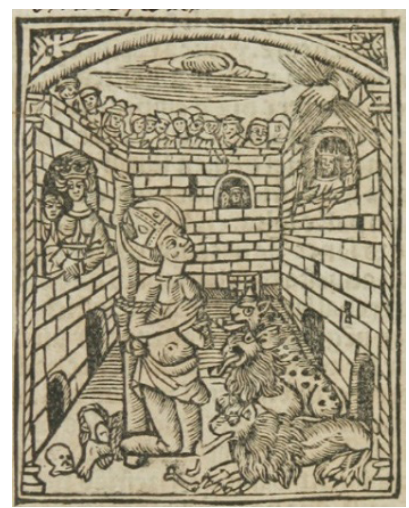

La vida de sanct Ignaci ([39]: f. LXVIII')
I 75

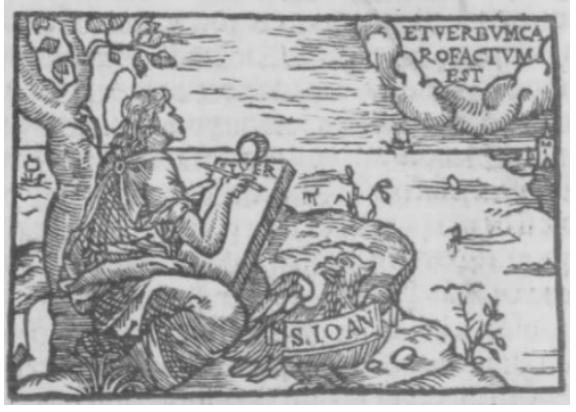

La vida de sanct Joan apòstol y evangelista ([II]: f. LXXX' $)^{7 \mathrm{o}}$

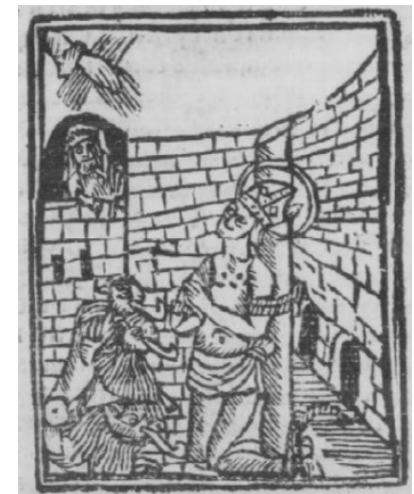

De sanct Ignaci $([39]$ : f. XXXXIII') 


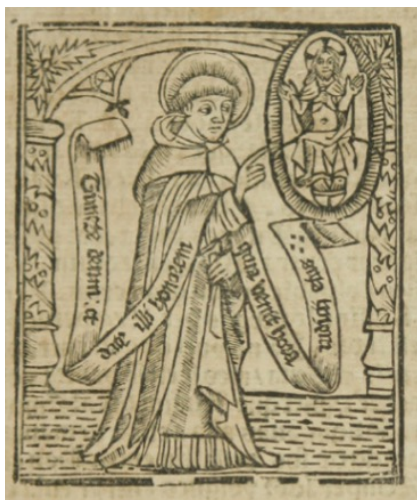

La vida de sanct Vicent Ferrer ([58]: f. C $)$

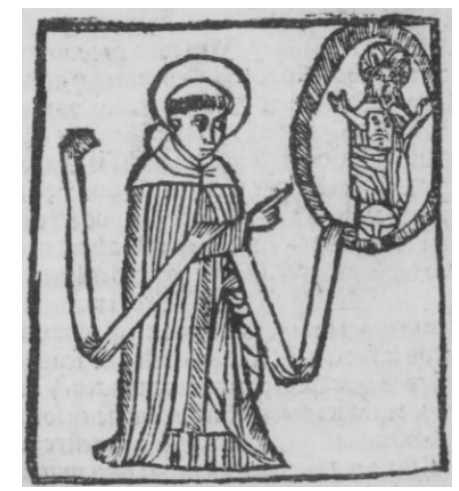

De sanct Vicens Ferrer ([58]: f. LXVc)

Els principals canvis estructurals que s'observen en aquesta edició tenen a veure amb l'omissió de capítols existents en edicions precedents, la inclusió de nous, i la reordenació d'alguns d'ells. Anem a pams.

Cal ressaltar, en primer lloc, que per a la composició d'I ${ }^{75}$ es degueren tenir en compte diverses impressions anteriors (almenys, $\mathrm{I}^{47}$, però també alguna altra precendent). Així doncs, s’hi dóna cabuda a la majoria de vides incorporades a la fi del santoral per I ${ }^{47}$ : inclou els capítols dedicats a sant Sever, santa Madrona, sant Segimon (tots tres ja presents des d'I'4), sant Serapió, sant Honorat, sant Elm, sant Bertrà, i també els capítols dedicats als sants Just i Pastor i a sant Magí, que, tot i que en ${ }^{47}$ apareixien intercalats en el gruix del santoral, ara aquests dos també s'han posat entre els capítols finals, entre els afegits posteriors al cos de l'obra de Voràgine que solen respondre a devocions locals, com són aquests dos casos. També, però, s’hi han recuperat vides que apareixien en altres edicions anteriors, i que $\mathrm{I}^{\mathrm{I} z}$ havia suprimit, com ara els capítols dedicats a santa Susanna, a sant Barlaam, o el capítol sobre la "Dedicació de l'Església”. No recupera, en canvi, altres capítols omesos en I"7, com la "Història de Mahomet" o la "Dels Reis de França", que ja en els incunables s'havien separat del capítol dedicat al papa Pelagi.

A la taula de continguts, com al títol, es declara que, de vides, "se n'i han posades y afegides moltes ara novament", i efectivament, a la fi de la compilació, s'han incorporat altres cinc nous capítols, però només en tres d'ells es declara explícitament que han estat "novament afegits": ${ }^{71}$ són els dedicats a sant Iu, sant Basili, i a la Passió dels deu mil cavallers màrtirs; atés que en els altres dos nous capítols que trobem, els dedicats a les vides de sant Francese de Paula i de santa Otília, no es declara que siguen cap novetat, podríem conjecturar si ja apareixerien en l'edició perduda de I548-49. Tanmateix, en la llicència obtinguda per a la impressió d'I ${ }^{25}$, que hem transcrit parcialment més amunt, s'especificava clarament que aquestes cinc noves vides afegides eren una novetat incorporada per aquests editors..$^{2}$

També en aquesta ocasió podem suposar que els continguts incorporats -o la majoria d'ellsintentarien satisfer els interessos dels devots, bé perquè el culte de determinats sants ja estiguera

7I. També per introduir el capítol dedicat a sant Magí indica: “La vida de sant Magí, la qual ací novament ara és affegida" (I75: f. CCI $\left.{ }^{a}\right)$, però en realitat és perquè manté la rúbrica que apareixia en I ${ }^{47}\left(\mathrm{f}_{\mathrm{CLI}}^{\mathrm{d}}\right)$, on s’incorporava com a novetat.

72. L’ordre dels capítols finals, després del que es dedica a Caterina de Siena (últim capítol de les edicions incunables) és el següent: vida de sant Sever (f. CXCVI ${ }^{d}$ ), vida de santa Madrona (f. CXCVII $)$, vida de sant Segimon (f. $\mathrm{CXCVIII}^{\mathrm{b}}$ ), vida dels sants Just i Pastor (f. $\mathrm{CC}^{\mathrm{b}}$ ), vida de sant Magí (f. $\mathrm{CCI}^{\mathrm{a}}$ ), vida de sant Serapió (f. CCII ${ }^{\mathrm{b}}$ ), vida de sant Honorat $\left(\mathrm{f}\right.$. $\left.\mathrm{CCII}^{\mathrm{c}}\right)$, vida de sant Elm $\left(\right.$ f. CCII $\left.{ }^{\mathrm{d}}\right)$, vida de sant Bertrà $\left(\mathrm{f} . \mathrm{CCV}^{\mathrm{a}}\right)$, vida de sant $\mathrm{Iu}\left(\mathrm{f} . \mathrm{CCV}^{\mathrm{c}}\right)$, vida de sant Francesc de Paula (f. $\mathrm{CCV}^{\mathrm{d}}$ ), vida de sant Basili (f. CCVII ${ }^{\mathrm{d}}$ ), el martiri dels deu mil cavallers (f. CCIX), i la vida de santa Otília (f. CCIX'). Vid. taula 2 de l'annex. 
arrelat, o bé perquè la conjuntura cultural i espiritual de la incipient Contrareforma enaltira determinats referents. La devoció per sant Iu, patró d'advocats i notaris, per exemple, ja existia a la ciutat. De fet, la porta més antiga de la catedral de Barcelona, i que aleshores feia d'accés principal, estava des del segle XV dedicada a aquest sant bretó. Potser, però, també cal recordar que era considerat un defensor de la possessió dels tresors econòmics de l'Església, encara que al text d'I75 no es fa cap menció explícita a aquest particular.

Poc sabem sobre el culte a la zona per Basili el Gran; en canvi, era tingut per un adalil de l'ortodòxia, destacat per la seua lluita contra l'heretgia arriana, un comportament força enaltit en els primers temps de la Contrareforma. La vida d'aquest sant, a més, apareixia en el corpus primigeni de la $L A$ ([26]), però havia estat omesa en les edicions incunables catalanes (tant en Inc. ${ }^{\mathrm{I}}$ com en Inc. $\left.{ }^{2}\right)$, i per tant, en la resta de reedicions del Cinccents. ${ }^{73}$ Només I ${ }^{75}$, que en ocasions sembla voler recuperar elements del corpus original de Voràgine, la inclou novament, en una traducció molt propera al text llatí primigeni. ${ }^{74}$

L’interés per sant Francesc de Paula, fundador de l'orde dels Mínims, també es corresponia amb l'admiració que despertaven a l'època els fundadors de noves ordes monàstiques que perseguien el retorn a la puresa primitiva del cristianisme. Així mateix, la "Passió dels deu milia màrtirs cristians", que esdevingué un motiu popularíssim en l'art del Cinccents, certament també podia adquirir una nova interpretació en el context de les guerres de religió. Sobre aquest capítol, cal especificar que el text de la "Passió dels deu mil màrtirs" que s’ha inserit en I75, és un text diferent, i molt més breu, del que presentava l'edició valenciana de Jorge Costilla ( ${ }^{\mathrm{I} 4}\left[{ }^{6} \mathrm{I}\right]$ : ff. $\mathrm{CXXII}^{\mathrm{b}}-\mathrm{CXXIIII^{ \textrm {a } } )}$ que també havia inclòs un capítol amb aquest contingut, pel que es confirma que no hi ha cap tipus d'influència de l'edició valenciana sobre cap de les catalanes.

En darrer lloc, més difícil resulta explicar la inclusió del breu relat de la vida de santa Otília d’Alsàcia, que ocupa el verso del darrer foli de la compilació. Però tant aquesta, com qualsevol de les altres noves incorporacions, es poden deure a altres motivacions menys profundes, com ara pel mer fet de disposar d'aquests materials. Cal dir que cap dels nous capítols afegits destaca particularment per la seua qualitat literària, i que semblen procedir d'altres compilacions de vides de sants.

D’altra banda, en l'edició de Cendrat i Montpezada també s'han suprimit diferents capítols dels que s'havien incorporat en les edicions de Carles Amorós, en concret la "Vida de santa Anna" i la "Història de l’Àngel Custodi” (presents totes dues ja des de l’edició d'I²4); la "Vida de santa Escolàstica” (introduïda en I7); i, així mateix, el brevíssim capítol dedicat al martiri “Dels set frares e llur mare", procedent del nucli originari de la $L A$. També s'ha resolt la duplicitat dels capítols dedicats a sant Feliu prevere, ja que, recordem, des de les edicions incunables s'hi inclö̈en dos textos diferents per narrar la vida del sant (Càmara 2OI3: XLVII); així doncs, s’ha eliminat el capítol més breu dels dos que se n'ocupaven, i s'ha mantingut només un d'ells (I75 [50]: ff. LIII'- LIIII $\left.{ }^{\mathrm{a}}\right)$.

Sembla que el revisor pretenia eliminar reiteracions en els continguts perquè el gruix de la compilació resultara més homogeni. El cas de la duplicitat de capítols dedicats a sant Feliu és evident. Però també a aquesta finalitat semblen respondre les supressions dels capítols de la "Vida

73. Pel que fa a les versions manuscrites, només la contenia el manuscrit de Vic (Rebull ed. 1976: 88-93). Es tracta del mateix relat que llegim en I5, és a dir, és la traducció del capítol de la $L A$, però es tracta de traduccions diferents que no semblen estar relacionades.

74. El capítol de sant Basili sí que es mantingué, en canvi, en les edicions castellanes del FS, i el relat que inclou el Flos sanctorum renacentista (des de la primera edició saragossana de Cocci de ${ }_{5} 5$ I6, vid. ff. CXXII $-\mathrm{CXXV}^{\mathrm{b}}$, fins a l'última de Sevilla, I580), és el mateix que apareix en I ${ }^{75}$, i tots dos són molt fidels al text de la $L A$. Tanmateix, en aquesta ocasió no sembla que el capítol haja estat pres del santoral castellà, ja que al text català no trobem alguns particulars de la redacció castellana (com ara noms de ciutats), i determinades lliçons del text català són més properes al text llatí que les que mostra el santoral castellà. 
de santa Anna" i de la "Vida de santa Escolàstica". El contingut del capítol de santa Anna era força semblant al del capítol de la Nativitat de Maria (I75 [I24]: ff. CXXXI ${ }^{\mathrm{b}}$-CXXXIII ${ }^{\mathrm{c}}$; i el mateix s'esdevé amb el capítol de santa Escolàstica, que com ja he explicat més amunt, en realitat, ja estava narrat, tot i que més breument, a la fi de la vida de sant Benet. A canvi de la supressió, però, en el capítol de sant Benet s'ha introduït una petita variació i ara s'hi explicita el nom de la santa, que no apareixia ni en la $L A$, ni en les edicions anteriors del FS: "Una vegada devallà sant Benet del monestir per visitar la seua germana santa Scolàstica, y axí com seyen los dos en taula, ella lo pregà que romangués la nit ab ella, mes ell no volgué consentir" ([ ${ }^{75}\left[5^{2}\right]$ : f. LVIII $\left.{ }^{\mathrm{b}}\right)$.

És més difícil conjecturar una hipòtesi que explique la supressió dels altres dos capítols, els dedicats al martiri de Felicitat i els seus set fills -brevíssim-, i a la festivitat de l’Àngel Custodi. Els nous santorals reformats continuen dedicant-los espai, encara que el text que reporten és ben diferent. Qui sap si l'editor n’ometé algun dels dos per descurança - pense en el dels set frares, per la brevetat-; o si el revisor preferí ometre'ls directament per guanyar espai per incloure nous afegits més atraients per als lectors potencials. Tampoc, però, es poden, ni es deuen, descartar motivacions diferents per a cada cas: per exemple, el capítol dedicat als àngels de la guarda, és un sermó de caire escolàstic poc representatiu de la devoció local pel sant patró, i, potser, el revisor no l'estimà adequat, o l'editor, atractiu.

El santoral presenta, a més, alguns canvis estructurals en la disposició dels capítols. A banda del desplaçament dels capítols dedicats als sants Just i Pastor i a sant Magí, que han passat del centre de la compilació a la part final, s'han ordenat de manera diferent alguns capítols de les festivitats del mes d'agost, variant l'ordre habitual que procedia de la $L A$. Sembla que el revisor, amb la intenció de millorar l'organització dels continguts, reuní les festivitats dedicades a sant Timoteu, sant Simforià i sant Hipòlit, ja que el martiri de tots tres es commemora, segons el Martirologi romà, en la mateixa data, 22 d'agost (encara que no s'hi explicita). 75 Tanmateix, sobta que els haja situat davant del dedicat a l'Assumpció de la Verge Maria (festivitat del I5 d'agost).

Tots aquests canvis estructurals i de continguts permeten concloure que l'edició de i575 presenta el gruix del corpus inicial de Voràgine notablement modificat, ja que, com a conseqüència de les diferents modificacions que s'han anat produint en la tradició editorial, en I ${ }^{75}$ apareixen vora vinti-cinc capítols menys dels originals de la compilació medieval, i, pel contrari, quasi quaranta noves incorporacions (cinc de les quals, exclusives d'aquesta darrera edició).

2.9.2 I ${ }^{75}$, un santoral de transició de sensibilitat postridentina

Com veiem, molts dels canvis estructurals i de contingut que presenta I75 poden explicar-se per les inèrcies editorials que s'han anat consolidant al llarg de la centúria, especialment pel que fa a la renovació de materials per intentar mantenir el producte vigent acostant-lo als interessos devots dels potencials lectors. Però, com ja he indicat, en aquesta ocasió s'aprecia que sí que s'ha realitzat una revisió del text més profunda que no les que hem pogut veure en les impressions anteriors. I si bé I ${ }^{75}$ continua sent la reedició d'un text de procedència medieval, s'hi han aplicat una sèrie d'estratègies orientades a adequar el contingut als criteris d'autoritat i autenticitat que exigia l’Església, i a reivindicar el profit del culte als sants.

75. De fet, en els santorals postridentis d'Alonso de Villegas i Pedro de Ribadeneira els tres capítols apareixen també reunits, i en el dia d'agost corresponent. 


\subsubsection{El pròleg d'I75 "Ad pium lectorem"}

Per primera vegada en la tradició editorial del santoral català, la compilació s'obri amb un pròleg, adreçat "Ad pium lectorem", que podria haver estat escrit pel dominic Pere Coll, o si més no, en les coordenades temporals d'aquesta edició, ja que els arguments que s'exposen en relació al culte als sants s'alineen clarament amb les noves directrius doctrinals postridentines.

Mentre que en la tradició editorial castellana del FS havia esdevingut habitual (fins i tot des de les primeres edicions incunables) la inclusió de preliminars que recordaven el profit de la lectura de vides de sants, en la tradició catalana del Cinccents mai no s'havia inclòs cap paratext específic amb aquesta intenció. El santoral pròpiament dit-vull dir, excloent els preliminars dedicats a la Passió-, només anava precedit del pròleg de Voràgine en què s'explicava la divisió del temps eclesiàstic al llarg de l'any litúrgic, calendari sobre el qual es bastia la macroestructura de l'obra. No és, per tant, fins a aquesta edició catalana del 575 que trobem un pròleg amb afirmacions sobre els beneficis d'aquestes devocions, i costa pensar que aquest escrit no estiga motivat directament pel clima religiós contrareformista. I no només pels arguments reunits, la majoria dels quals no gaire originals, sinó per la manera amb què es fonamenten, basant-los en autoritats reputades -que són citades amb precisió-, i per la intenció contestatària a què semblen obeir.

Així, l'artífex del pròleg, en primer lloc, enumera un seguit de veus d'autoritat que recorden que el fi últim de l'home és servir Déu fent bones obres que el porten a gaudir de la glòria del Paradís. El raonament, òbviament, cobra ple sentit en la controvèrsia luterana de la justificació per la sola fe, ja que la posició catòlica defensava aferrissadament la necessitat de fer bones obres per guanyar la Salvació, i l'exemple dels sants, com a models de vida per als cristians, esdevenia imprescindible per a tal fi. Així doncs, s'hi apel-la a l'autoritat de Pares de l'Església que avalen la defensa de fer bones obres; també s'hi reforça el missatge mencionant autors gentils, com Aristòtil; i, fins i tot, s'hi recorda el que diuen les Sagrades Escriptures (de l'Antic i del Nou Testament), en la veu del profeta David, de sant Pau, o del mateix Jesucrist, ja que una altra important controvèrsia en relació al culte als sants tenia a veure amb l'argument ex silentio Scripturae, defensat pels luterans:

Conclusió és molt certa, y doctrina molt cathòlica de l'angèlic doctor sant Thomàs, en lo seu llibre anomenat La prima secunde, en la "Qüestió primera" y en molts altres llochs de la sua scriptura, y de Escot, en lo seu "Quart" de les Sentències, en la "Distinció quaranta nou” de Ricart, y Bonaventura, en lo mateix lloc, y finalment és conclusió de tots los doctós theòlechs, que lo fi ultimat per al qual Déu omnipotent ha creat la racional criatura, que és l'home, és aquella celestial glòria de paradís (...). Fins a Aristòtil, príncep dels philòsophs, en llum natural alcança esta veritat, dient en lo "Primer" de les Èthiques [com] la benaventurança és lo fi y paga de les virtuts y bones obres, que són los medis convenients [ab qu]e.s alcança aquestos deguts y convenients medis. Ensenyava nostre Senyor dient: "Si voleu [chri]stians alcançar aquell fi ultimat de la glòria, apreneu de obrar les virtuts y bones, que són los convenients medis per alcançar-lo ([75: f. [I] $\left.{ }^{\mathrm{r}}\right)$

Després d'argumentar amb veus autoritzades -convenientment citades, com reclamaven els reformadors- que per fruir del Paradís calen les bones obres, el discurs s'orienta cap a la necessitat que els fidels disposen de bons models que puguen imitar per fer aquestes bones accions, i és així com es justifica la necessitat del culte als sants, ja que, amb l'exemple de llur vida, mostren el camí i els graons de la "dreta escala" per muntar al cel. ${ }^{76}$ Aquest no és un argument gaire novedós; el que sí que ho és, és declarar que ha estat l'Església la que ha ordenat que s’arreplegaren i difongueren

76. Recordem que alguns decrets del Concili, com el de la reafirmació del valor de les obres juntament amb la fe (Sessió VI, I3 de gener de I547), ja havien posat en relleu el valor del culte als sants i la necessitat de retornar el seu culte a l'estatus que li negaven les posicions protestants (Martín del Burgo 2OI9: I6). 
aquests tipus de relats. No deixa de ser una estratègia de l'autor del pròleg per legitimar la matèria i aquest compendi en particular, i presentar-lo així com un text resultant dels dictats tridentins: "Y perquè tinguéssem certa regla, se ordenà en la Església que·s fes una congregació dels actes heroics que els sants han fet en llur vida, perquè llegint nosaltres les vides que.ls sants han fet en la terra, imitant-los, alcancem lo fi de la glòria que ells han ja alcançat" (I75: f. [I] $]^{\mathrm{v}}$ ).

A la resta del pròleg es reuneixen alguns tòpics relacionats amb la devoció pels sants tampoc gaire originals, i que ja apareixien en els preliminars dels santorals renaixentistes castellans des de fa dècades. Per exemple es glossa el significat del títol, "flor dels sants": 77

perquè és com un ram de flos: quant fem un gentil ram, que y posam diverses flors, dient-li ram de flos, ço és, ajust de moltes flos, axí aquest llibre se diu lo ram de les flos dels sancts, perquè en ell se contenen diverses vides de sants, y cada hu d'ells és estat una flor en la Església. Y més, se diu Flor dels sants perquè com per gala del cos folgam de aportar un ram de flos en la mà, axí també per gala espiritual de la nostra ànima devem aportar en les mans, ço és, en la obra, per vera imitació, les flos y vides dels sancts. ([75: f.[I] $\left.]^{v}\right)$

I es recorda el profit de llegir textos de devoció en comptes de textos de ficció, en concret llibres de cavalleries, que no aporten cap ensenyament moral ni edifiquen el lector: $7^{8}$

Lo ram de les flos del món, per moltes flos que tinga, se fa musti perdent la olor, y encara que posant-los en aygua algun poc se detinguen, totavia se sequen; axí molts se deliten en comprar llibres de cavalleries y farces, qu·és tot mentida, y acabat de llegir se pert la fragància, perquè no·n reben utilitat alguna, sinó dany per a l'ànima (...); però los qui porten aquests rams de verdaderes flos y vides dels sancts benaventurats, llegint aquelles e imitant-los per vera y sana imitatió, porten uns tals rams y de tant precioses flos adornats, que may perdran la olor y fragància que tenen, per que.ns mostren los modos y medis condignes com havem de alcançar aquella eterna glòria de Paradís. ([75: f. [I] $]^{\mathrm{C}}$

Només cap a la fi, sobre aquesta edició en concret, s’afirma que: "si en qualsevol altra impressió se ha pogut nomenar ram, o flor dels sants, amb més raó aquest present llibre se deu anomenar la flor dels santcs, perquè és bé emendat, havent-li llevat moltes coses supèrflues y havent-hi ajustat altres coses necessàries y altres vides de sants molt devotes" (I75: f. [I] $]^{\mathrm{v}}$. La declaració de la revisió podria semblar, novament, un lloc comú més, ja que solia ser una fórmula habitual en la literatura del Cinccents quan un text era reeditat, encara que aquesta revisió haguera estat força superficial. ${ }^{79}$ Però, certament, en aquesta ocasió s'acompleix tot el que es declara; s'hi han afegides noves

77. L'incunable de la Leyenda de los santos castellana ja indicava en el prefaci que l’obra "común e vulgarmente se llama flos sanctorum, porque aquí no están así por entero las vidas e historias de los sanctos, como en el Vitas Patrum, mas está lo más escogido e la flor de cada vida" (Baños 2OI8b: 36 ). En realitat, però, era un tòpic força glossat, pràcticament des de la primera vegada que es féu servir al segle xIv, per Johannes Gobi a la Scala Coeli (Martín del Burgo 2019: I8).

78. Al pròleg a l'edició del Flos sanctorum renacentista, imprés a Saragossa per Jorge Cocci en I5ı6, i sembla que revisat per Pedro de la Vega, es llig “cuánto son dignos de reprehensión los que, dexada aparte e postpuesta la leción deste libro, se ocupan de todo su coraçón en los tratados vanos e seglares, e llenos de fablillas de los poetas (...). Pues si te deleitan los hechos maravillosos e por la mayor parte fingidos de los esforçados cavalleros, que puestos en las batallas no supieron bolver las espaldas, lee en este libro e verás los triunfos muy gloriosos de los apóstoles, que con solas las armas de su fe vencieron todo el mundo. Rebuelve estas historias e sabrás por su muy verdadera relación cómo los santos mártires puestos en la batalla de los tormentos antes les faltó la vida que el esfuerço" (Baños 2Or8b: 38).

79. De fet, ho hem comprovat en el cas d' $\mathrm{I}^{24}$, que s'anunciava al títol com a novament revisada, mentre que el text no presentava gaires variacions significatives respecte de l'edició incunable. 
vides (com ja he explicat més amunt), i el text també ha estat esmenat. S’hi han eliminat el que el prologuista denomina "coses supèrflues" -que d'altres autors coetanis dirien apòcrifes-, i s'hi han afegit "d'altres necessàries" -normalment veus d'autoritat, com veurem-. És a dir, s'han aplicat sobre el text les altres dues línies d'intervenció que he descrit per tal legitimar la matèria, i provarne l'autenticitat i l'autoritat que la secunda.

Amb la inclusió d'aquest breu pròleg, doncs, l'obra s'alineava amb les actuacions catòliques de la defensa del culte al sants, d'una banda, i amb la vindicació de fer bones obres per guanyar la glòria, de l'altra. I amb les cauteles anunciades sobre la revisió, es fa evident que hi havia latent un desig per acréixer la qualitat del text des de l'òptica tridentina.

\subsubsection{La revisió dels passatges apòcrifs}

Com he recordat suara, la declaració que el text ha estat "bé emendat, havent-li llevat moltes coses supèrflues" sembla tenir molt a veure amb la revisió de passatges apòcrifs, una cautela en l'edició de l'obra que s'alinea amb els dictàmens postridentins sobre la supervisió de la matèria hagiogràfica, $\mathrm{i}$ que ja havien aplicat a llurs compilacions els principals hagiògrafs europeus, com ara Lippomano i Surio.

Ja més amunt he recordat que una part important de la controvèrsia sobre el culte als sants es basava en la problemàtica dels passatges apòcrifs que apareixien en els textos hagiogràfics, la presència dels quals restava crèdit al conjunt dels relats. En un primer moment l'eliminació d'aquests passatges fou discrecional, a parer dels revisors, però a poc a poc, la censura inquisitorial anà decretant quines afirmacions havien de ser porgades dels santorals.

El revisor del $F S$ de 1575 sembla preocupat per aquesta problemàtica, però mostra poca cura 0 destresa a l'hora de cancel-lar determinats passatges. Un dels exemples més evidents, el trobem al capítol de la Nativitat de Jesucrist, en relació al popular episodi de les suposades parteres que assistiren la Mare de Déu en el part. Aquest episodi apareixia ja al Protoevangeli de Jaume, i relata com Maria fou assistida per unes llevadores que foren testimonis de la seua perpètua virginitat. S'hi explica que una d'elles, Salomé, dubtà d'aquest misteri i tocà la Mare de Déu per tenir confirmació de la seua virginitat després del part $\mathrm{i}$, com a càstig per la seua incredulitat, se li assecà el braç. Probablement l'anècdota tenia un origen popular, i hauria sorgit per dissuadir els recels que suscitaven alguns misteris (Puig 2008: 197). Molts autors catòlics desconfiaven de l'origen de l'episodi, i de fet, ja alguns textos marians de final de l'edat mitjana l'havien suprimit en els relats de la Nativitat..$^{80}$ Tanmateix, els flores sanctorum continuaven difonent-lo en el capítol de la Nativitat de Jesús, com la quarta raó que demostrava la perpètua virginitat de Maria, "per experiència de fet".

El revisor de l'edició de I575 intervingué en aquest punt del relat per suprimir l'episodi, però sobta la poca cura amb què resolgué la qüestió, sense preocupar-se per esmenar la redacció del text resultant, que roman de la manera següent:

8o. Un exemple seria La vida de la sacratíssima verge Maria de Miquel Peres, publicada per primera vegada a València en I494, però que tingué una gran acollida a les premses tant en català com en castellà al llarg de la centúria (Arronis 20I5: 85-96). 


\begin{tabular}{|c|c|}
\hline $\begin{array}{c}I^{19-20} \\
\text { [8] "La Nativitat de Jesuchrist" }\end{array}$ & [8] "La Nativitat de Jesuchrist" \\
\hline $\begin{array}{l}\text { La quarta, per experiència de fet, car, com lo } \\
\text { temps de l'infantar s'acostàs, segons que hom } \\
\text { troba en la Compilació de fra Barthomeu -la } \\
\text { qual cosa sembla que sia stada treta del Libre } \\
\text { de la Infantea del Salvador-, que Joseph, } \\
\text { jatsia no duptàs que.l Salvador devia nàxer de } \\
\text { la Verge, emperò volgué servar la costuma, e } \\
\text { féu venir levadores que levassen l'infant, de } \\
\text { les quals, la una havia nom Zabel, e l'altra, } \\
\text { Salomé. E Zabel, com guardàs sancta Maria e } \\
\text { la trobàs verge, cridà que verge havia infantat; } \\
\text { e Salomé, com no cregués, e açò volgués } \\
\text { provar semblantment com Zabel, de continent } \\
\text { fon dèbil de la mà. Emperò, per manament } \\
\text { de l'àngel, Salomé tocà l'infant d'aquella } \\
\text { mà e tantost fon guarida. La V manera, per } \\
\text { evidència del miracle (...) (f. XIX })\end{array}$ & $\begin{array}{l}\text { La quarta, per experiència de fet, car com lo } \\
\text { temps de l'infantar s'acostàs, segons que hom } \\
\text { troba en la Compilació de fra Barthomeu -la } \\
\text { qual cosa sembla sia estada treta del Libre de } \\
\text { la infantesa del Salvador-, que Joseph, jatsia } \\
\text { no duptàs que.l Salvador devia nàxer de la } \\
\text { Verge, emperò volgué servar la costuma. La V } \\
\left.\text { manera per evidència del miracle (...) (f. XIV }{ }^{b}\right)\end{array}$ \\
\hline
\end{tabular}

Precisament la supressió d'aquest passatge esdevingué prescriptiva a començaments del segle següent. En i6r 4 es publicà un Apèndix que completava l'Índex de censura i expurgacions que en I6I2 havia ordenat l'inquisidor Bernardo de Sandoval. En aquest apèndix es dictaminava expurgar aquest passatge sencer (Sandoval I6I4: 865), i no parcialment, com havia fet el nostre revisor. Com a conseqüència d'aquest manament, les edicions anteriors dels flores sanctorum que contenien aquest passatge foren expurgades, i per això en alguns dels testimonis de santorals que s'han conservat, l'episodi apareix ratllat. Ho veiem en l'únic testimoni conservat de l'Inc. ${ }^{2}$ ([8]: f. XIXv) i en el testimoni d'I 47 ([8]: f. XXIr- XXI $\left.{ }^{\mathrm{r}}\right)$.

En d'altres punts del santoral, les intervencions sobre el text per revisar-ne l'autenticitat han estat molt més subtils. Val a dir que, en general, el revisor és força respectuós amb el text català, però sembla que l'ha supervisat acarant-lo amb una edició llatina acurada, cosa que li ha permés recuperar determinades advertències que apareixien al text de Voràgine sobre la naturalesa apòcrifa de certs passatges, advertències que s'havien suprimit en les versions en romanç: "E llig-se en una història dels grecs apòcrifa que l'àngel li donà del fust en què pecà Adam" (I75 [66]: f. LXXII ${ }^{\mathrm{d}} .^{8 \mathrm{r}}$

La lectura minuciosa del volum fa evident que la prevenció per evitar o per indicar allò apòcrif fou un dels principals esforços escomesos pel curador del text. Malgrat tot, la revisió, ni sembla ser exhaustiva, ni sistemàtica, i segons cada cas, es va optar per aportar una solució diferent. Però amb major o menor destresa, es fa evident que hi era latent la cautela per evitar allò de procedència dubtosa, o que no estava documentat per autors greus, de prestigi, o que no era d'autenticitat provada, $\mathrm{i}$ convé recordar que aquesta fou una de les directrius principals de què partiren els nous hagiògrafs contrareformistes de la Modernitat. ${ }^{82}$

8I. Fragment procedent de capítol “Del trobament de la creu” (ff. LXXII ${ }^{\mathrm{c}}$ - LXXIII ${ }^{\mathrm{d}}$ ). En les edicions anteriors, la referència a la naturalesa apòcrifa d'aquesta "història" havia estat eliminada.

82. Es pot comprovar, per exemple, en relació a les estratègies emprades pel jesuïta Pere Gil i pel dominic Antoni Vicenç Domènech en llurs respectives compilacions hagiogràfiques modernes (vid. Arronis en premsa). 


\subsubsection{Claredat expositiva i presència d'autoritats}

L’ambició del revisor del volum, però, excedeix les precaucions envers els passatges apòcrifs. Recordem, a més, que al pròleg es declarava que el text s'havia esmenat "havent-li llevat moltes coses supèrflues y havent-hi ajustat altres coses necessàries”. Certament, hi descobrim també la voluntat de millorar el contingut d'alguns capítols, sobretot a través de dos tipus d'intervencions: revisant l'estil del text per tal que siga més entenedor, i acreixent la presència d'autoritats i de passatges bíblics sobre els quals es justifica la doctrina. Observem l'aplicació d'aquestes estratègies principalment en els capítols corresponents a festivitats mariològiques, és a dir, aquells on s'exposen dogmes i misteris de la fe catòlica. Hi ha per tant, la voluntat d'acréixer i millorar el vessant més purament doctrinal, una altra preocupació ben característica de la Contrareforma.

De la mateixa manera que resultava problemàtica la presència de passatges apòcrifs, els teòlegs postridentins també es mostraven preocupats per la necessitat de reforçar la doctrina referint a fonts d'autoritat, i d'evitar exposicions i argumentacions que resultaren de difícil comprensió. De fet, una de les qualificacions freqüents que poden trobar-se en els índexs de censura del Cinccents en relació a les obres devotes i que indica el seu caràcter problemàtic, té a veure amb la presencia d'un estil malsonant. Vega (20I4: I47-48) recorda que aquesta qualificació sovint depenia de la discreció del censor, però en general es considerava malsonant una exposició farragosa o poc avesada en matèria de religió o de fe que podia dificultar-ne la comprensió. Potser aquesta cautela explicaria per què alguns capítols de difícil lectura han estat reescrits, millorant l'exposició de la doctrina i actualitzant el lèxic quan s'ha considerat menester. El capítol de la Purificació de la Mare de Déu, per exemple, ha estat esmenat completament per facilitar-ne la comprensió. Així mateix, al llarg de tot el capítol s'han aportat bé autoritats, o bé la localització precisa de determinats versicles bíblics, per tal de reforçar l'autoritat de la doctrina. Podem apreciar totes dues estratègies en el fragment següent:

\begin{tabular}{|c|c|}
\hline $\begin{array}{c}\text { Inc. }^{2} \\
\text { [4I] "De la Purificació de la verge Maria" }\end{array}$ & $\begin{array}{c}I^{75} \\
\text { [4I] "De la Purificació de la Verge Maria" }\end{array}$ \\
\hline $\begin{array}{l}\text { La purificació de la Verge Maria fon feta aprés } \\
\text { de la Nativitat de nostre Senyor Déu Jesucrist } \\
\text { quaranta dies. }\end{array}$ & $\begin{array}{l}\text { La purificació, segons la lley, de la puríssima } \\
\text { verge Maria fonc a xl dies aprés de la Nativitat } \\
\text { de nostre Senyor Jesuchrist. } \\
\text { La història de la festa scriu sant Lluc en lo } \\
\text { segon capítol de son Evangeli dient: “Aprés } \\
\text { que foren complits, segons la lley, los dies de } \\
\text { la purificació de la verge Maria, aportaren } \\
\text { lo infant a Hierusalem a presentar al Senyor, } \\
\text { ço és, al temple. E aportaren-lo-y per donar } \\
\text { per ell en sacrifici un parell de tortres ho } \\
\text { dos colomins, per fer per ell lo que segons } \\
\text { la costuma de la lley era manat. E havia-y un } \\
\text { home en Hierusalem que·s dehia Simeon, y } \\
\text { aquest era just y temerós de Déu, y esperava la } \\
\text { consolació de Israel, y l'Esperit Sant estava en } \\
\text { ell. Y havia aquest sant home haguda revelació } \\
\text { del Sperit Sant que ell havia corporalment de } \\
\text { veure a Jesuchrist encarnat ans qu·ell morís. Y } \\
\text { en la hora que el Senyor fou aportat al temple } \\
\text { li fou revelat per lo Sperit Sant y manat que y }\end{array}$ \\
\hline
\end{tabular}


Solie's nomenar aquesta festa en tres maneres, ço és, Purificació e Ypopanti e Candelera. És dita Purificació per ço com al quaranta dia de la nativitat de Jesucrist venc la Benaventurada al temple per ço que ella fos mundada, segons la costuma de la vella ley, ja fos açò que ella no fos tenguda sots aquella ley. Mana la ley en lo libre qui és appellat Levítich, en lo XII capítol, que fembra concebent per sement de home e infantàs fill que fos no neta, que-s guardàs per VII dies de acostar-se a home, e que no entràs en lo temple. Mas complits los VII dies, que fos neta, se podia ajustar ab home, mas encara a XXXIII dies quant a l'entrament del temple era $<$ no $>$ neta. Mas, al xL dia entrava en lo temple e offeria l'infant ab offertes. E, si havia filla, ella doblava los dies quant a l'entrament del temple.

\section{(...) La terça raó és que per ço és donat a} entendre que la dona en alguna manera fatiga més a Déu que l'home per ço car la dona més greument pecca que l'ome, car Déu en alguna manera és fatigat en les nostres obres malvades, perquè ell diu "Servey me feu en les vostres iniquitats"; encara més: "Treballs sostén". (f. LXI"-LXI") anàs a veure'l; y corrent, aquest benaventurat vell al temple isqué a rebre al redemptor, y posats los genolls en terra adorà'l y pres en los braços, y dix ab gran alegria: 'Ara Senyor, dexes a ton servent, segons la tua paraula, en pau, pus que han vist mos ulls a ton fill, Salvador nostre, lo qual prepareu devant la presència de tots los pobles, perquè Ell sol és llum per la revelació e il.luminació de les gents y per a glòria del teu poble Israel'."

Gran, per cert, és la solemnitat d'esta festa per diversos misteris que en ella seguiren. La qual és exalçada per III coses principals que.s celebraren aquest dia: la I és la presentació de Jesuchrist en lo temple; la II, la offerta que segons la lley donaren son pare y mare per ell; la III, la consolación [sic] de Simeon. Y segons estes tres coses, esta festa és anomenada en tres maneres, y açò és Purificació, Presentació, Candelera ofesta de llum. Diu-se purificació, que vol dir netejament, perquè al cap de quaranta dies aprés de la Nativitat de nostre Senyor redemptor anà la gloriosa verge Maria a purificar-se al temple, y açò segons la costuma de la Lley de Moysés, encara que no fos ella obligada a tal lley ni manament perquè Moysés manà (als XII capítols del Levítico) que la dóna que rebria sement en si y parís fill, fos tinguda per no neta set dies, y se apartàs aquells VII dies de ajustament de home y de entrar en lo temple; y complits los VII dies, fos neta per a conversar ab home, mes no per a entrar en lo temple fins fossen passats trenta y tres dies més, de manera que tots los dies de son apartament fossen quaranta. Y complits los quaranta dies de la sua purificació, entrava llevós al temple, y offeria allí son fill ab les offertes que eren manades offerir en la lley. E si la dona paria filla, havien-se de doblar estos dies, car se havia de abstenir catorze dies de ajustament de home, y sexanta y sis dies de entrar al temple, en manera que fossen per tots LXXX dies.

(...) La III és perquè-s fos donat a entendre que més anuja a Déu la dona que l'home per quant peca més, car Déu en alguna manera és treballat y anujat en nostres perverses y males obres, segons ho diu Ell mateix als quaranta y tres capítols de Isaỹes: "Fereu-me servir en vostres pecats". Y en lo primer capítol del matex Isaÿes diu: "Traballí suffrint" (ff.

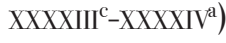


Comprovem com s’intenta que l'exposició dels continguts resulte més entenedora, simplificant la sintaxi i afegint les paràfrasis necessàries per assegurar-ne la comprensió. D’altra banda, la incorporació d'autoritats -en aquesta ocasió la llarga cita inicial de l'evangeli de Lluc, o l'especificació de la procedència dels versicles que veiem a la fi del fragment- reforça l'aspecte doctrinal del text, i recorda que l'exegesi especulativa parteix de la paraula bíblica.

Són nombrosos els exemples que podríem citar en què s'apliquen aquestes estratègies adreçades a assegurar la comprensió de la doctrina i a reforçar l'exposició de l'exegesi. Tanmateix, tampoc aquest aspecte és general en l'obra, ni se n’ha fet una revisió sistemàtica. Sembla, més aviat, que només s'han reescrits aquells capítols que, o bé evidenciaven una major urgència, o bé s'estimaven més significatius per la càrrega doctrinal que contenien. Val a dir, però, que el revisor, encara que en molts altres capítols no modifica el text, sí que ha esmenat la majoria de les lliçons errònies que eren presents en les edicions anteriors, com ara algunes de les que hem vist en els exemples més amunt. $^{83}$

\section{La desaparició de les compilacions generals en català de les premses}

L'anàlisi que he presentat, doncs, fa evident que el contingut del FS de I575 fou revisat a bastament, encara que no de manera exhaustiva ni sistemàtica. Com ja he advertit més amunt, no podem conjecturar quines d'aquestes modificacions, tant estructurals com estrictament textuals, són exclusives d'I75, atés que no conservem cap testimoni de l'edició anterior ( $\left(\mathrm{I}^{40^{8}-49}\right)$, que, com he argumentat, probablement prengué com a base. No obstant això, la revisió de naturalesa doctrinal que s'observa al text, amb què s'ha tractat d'adequar el contingut a l'ortodòxia i el rigor que l’Església exigia per als textos hagiogràfics després de Trento, sembla ser, com el pròleg, responsabilitat del prior dominic Pere Coll, i hauria estat realitzada en aquelles dates. Coll era conscient dels paranys que la reedició d'un text de procedència medieval podia comportar: calia prescindir de passatges de procedència dubtosa, blindar d'autoritats la doctrina, i adequar l'estructura i l'estil quan fóra menester, per evitar duplicitats de contingut innecessàries, o per millorar la redacció de fragments confusos.

L'edició de I575, per tant, reflecteix els darrers esforços per intentar mantenir vigent un santoral de procedència medieval en la nova cruïlla espiritual i teològica del darrer terç del Cinccents, però els tímids esforços del revisor no foren suficients per redreçar un text medieval als nous estàndards crítics que s'exigia a l'hagiografia en el període postridentí. Malgrat les intervencions puntuals, el gruix de la compilació continua reproduint l'obra medieval amb els elements que provocaren el seu descrèdit: presència d'etimologies infundades, declaració exigua de les fonts d'autoritat, poca cura del rigor històric, relats que només inclouen miracles (és a dir, allò que admira i no allò que edifica), etc. ${ }^{84}$ De fet, no se'n féu cap altra edició posterior, malgrat que la llicència que Jaume Cendrat havia obtingut del lloctinent de Felip II, li permetia imprimir aquest santoral en exclusiva per deu anys.

83. Comprovem, per exemple, com ha resolt les lectures errònies que oferien els casos i i 4 vistos més amunt (a l'apartat 2.4) presents en edicions anteriors: (I) "Mes los phýsichs diuen que lo cos de l’home no és acabat de formar fins a quaranta y sis dies (I75: f. XXXXV")"; (4) “Lo IX profit és apparellament del lloc, segons que diu sant Joan en lo XIII capit.: Vaig aparellar a vosaltres loch" ([75: f. LXXVI').

84. Recordem que ja en I532 l'humanista Joan Lluís Vives havia estat molt crític amb la $L A$, qüestionant irònicament, fins i tot, per què se la considerava 'daurada', quan li semblava "scripta sit ab homine ferrei oris, plumbei cordis", i considerava que aquest santoral era una vergonya per als cristians, per la poca cura i precisió amb què s’havien transmés les vides dels sants (Thompson I990: Io6). 
Recordem que en la llicència, citada més amunt, es posava en valor, a l'hora de concedir-la, el fet que el text havia estat revisat i esmenat pel dominic Pere Coll, i que comptava, així mateix, amb una llarga tradició en llengua catalana, que finalitza, però, amb aquesta edició. I no només finalitza la tradició editorial del FS català, sinó la dels grans santorals generals, ja que no se’n publicarà cap altre en català en l'edat moderna.

Només tres anys després es publicà el primer volum del Flos sanctorum "reformat" del clergue toledà Alonso de Villegas ( $57^{8}$ ), que prompte es completà amb quatre toms més (publicats entre I583 i I594), com així mateix, el Flos sanctorum del jesuïta Pedro de Ribadeneira (vol. I en I599, i vol. 2 en i6o4), gestats tots dos seguint el model del santoral de Lippomano-Surio que superava les compilacions medievals. Aquests nous santorals generals assumien plenament les noves premisses teològiques i criteris metodològics que s'havien imposat arreu de l'Europa catòlica pel que fa a l'hagiografia. Aquestes compilacions castellanes tingueren un èxit fulgurant a tota la Península, i també en altres indrets, ja que foren traduïdes a diverses llengües europees. En el context català, sense necessitat de traducció, també satisferen els anhels d’un públic lector que, en bona mesura, i en determinats cercles, ja era bilingüe i sembla que podia accedir als santorals castellans sense gaire dificultats. No deixa de ser simptomàtic el fet que el mateix Jaume Cendrat imprimira diversos toms del Flos sanctorum de Villegas al seu taller de Barcelona: el tercer tom, en I588 (dedicat a la vida de sants extravagants i barons il.lustres i virtuosos), i el quart, en I590 (que s'ocupa de sermons de les festivitats del cicle litúrgic). ${ }^{85}$

Al context català, i en llengua catalana, no es féu cap compilació general equivalent, però això no significa que no trobem iniciatives paral-leles orientades a la revisió de la matèria hagiogràfica, sovint entesa encara com una manera de fer front a l'expansió de l'heretgia protestant. Aquests esforços, però, se centraren prioritàriament en la recuperació i l'enaltiment de l'hagiografia pròpia del territori. ${ }^{86}$ En són bona prova tant el recull inacabat de Vides de sants de Catalunya del jesuïta reusenc Pere Gil (c. I60o), com la Historia general de los santos y varones ilustres en santidad del Principado de Cataluña, del dominic gironí Antoni Vicenç Domènec (impresa a Barcelona en I6O2 i, de nou, a Girona en I63o). ${ }^{87}$ I és que les poques dècades que separen la darrera publicació del Flos sanctorum català, i l'elaboració de les primeres compilacions de sants locals, són suficients per dibuixar un context espiritual considerablement diferent. A les darreries del Cinccents, la penetració progressiva de l'esperit tridentí a les diòcesis és ja un fet, i va concretant-se en reformes puntuals i accions pròpies de cada indret, sovint adreçades a la reivindicació del passat catòlic dels territoris, cosa que contribuirà a l'àuge de l'hagiografia patriòtica. Des del punt de vista de la revisió hagiogràfica, el model dels nous santorals reformats s'ha consolidat, i les noves compilacions ja es difonen arreu. Són el model, però no abasten la totalitat de les devocions existents. Queda pendent ampliar aquestes compilacions, revisar i completar allò que els primers santorals reformats encara no han atés, i posar en valor les històries dels màrtirs locals, i aquest serà l'objectiu principal dels primer hagiògrafs catalans moderns.

85. Per entendre la gran acollida de l'obra de Villegas, n'hi ha prou amb destacar que en menys de quinze anys, entre I586 i I600, només a Barcelona es compten vint edicions de diferents toms d'aquest santoral, en molts casos fetes pels principals editors de la ciutat, com el mateix Cendrat, o Damià Bagès, Francesc Trinxer, Hubert Gotard, Jeroni Genovés, etc.

86. Johannes Molanus ja havia explicitat la conveniència perquè a cada territori es prengués cura "suae nationis Sanctos”, com ell feia amb el seu Indiculus Sanctorum Belgï (I573), que completava el martirologi d'Usuard que ell mateix havia revisat i esmenat pocs anys abans (I568).

87. Vid. una caracterització d'aquestes compilacions i de les principals motivacions a què responen, a Arronis (en preparació). 


\section{Conclusions}

Aquesta primera caracterització de la tradició editorial del FS català del Cinccents, permet concloure que les transformacions que s'hi observen segueixen les dinàmiques esperables en aquest tipus de devocionari, semblants a les que mostren altres tradicions editorials del context romànic. La compilació no és percebuda com un devocionari tancat, sinó que cada edició intenta superar l'edició anterior acreixent els materials reunits. Aquests capítols són de naturalesa ben variada, i de diversa qualitat literària en base a la seua procedència. La majoria de les noves incorporacions semblen voler respondre a les preferències devotes dels lectors potencials; s'hi inclouen moltes vides de sants màrtirs i eremites, principalment de la zona de Barcelona, però també vides d'altres sants no catalans que probablement també eren venerats, bé perquè el seu culte s'haguera estés per altres motius (com ara per ser patró d'algun gremi en particular, o protector contra algun perill), o bé per tractar-se de sants fundadors de noves ordes monàstiques, de gran interés en una època d'efervescència de la refundació de les ordes religioses. Cal posar en valor, doncs, l'esforç dels impressors per mantenir el santoral vigent $\mathrm{i}$ atraient per als devots, encara que no sempre foren destres a l'hora de seleccionar els materials o d'evitar duplicitats.

Pel que fa a la procedència d'aquests afegits, convé notar que en la tradició catalana s'observen alguns transvasaments de materials procedents de santorals de la tradició castellana; he pogut detectar préstecs tant de la Leyenda de los santos com del Flos sanctorum renacentista, però de segur que futures anàlisis, que examinaren, per exemple, santorals francesos i llatins, ajudarien a explicar la procedència d'altres capítols nous, cosa que ens permetria establir hipòtesis interessants sobre els circuits editorials i els intercanvis de materials devots. D’altra banda, paga la pena notar que alguns capítols afegits tenen un estil molt acurat, pel que es podria considerar que hagueren estat difosos inicialment com a vides exemptes.

El cristocentrisme, que ha amerat la religiositat dels darrers segles medievals, fa que la presència de l'exemple de Crist siga imprescindible com a model de les vides dels sants, ja que llur passió sempre serà a imitació de la Passió de Crist. Els FS castellans manuscrits ja incorporaven afegits sobre la Passió i la vida de Crist, però no és fins a començaments del XVI que ho veiem en la tradició catalana, amb la inclusió d'uns preliminars sobre la Passió, i altres escrits afins, com les epístoles de Lèntul i de Pilat, precisament seguint el model de la Leyenda de los santos.

Els aspectes formals, especialment en les edicions d'Amorós, també funcionaren com a reclam per mantenir atractiva la compilació; els gravats, cada vegada més rics i detallats, permetien ampliar l'experiència devota. En canvi, les variacions que s'aprecien en el text respecte de l'edició incunable, són mínimes en la majoria de les edicions, i responen normalment a qüestions merament ortogràfiques. Menció especial cal fer en aquest sentit a l'edició valenciana de Jorge Costilla de I5工4, que, en un intent de modernització del text, realitza una revisió general i sistemàtica de la llengua i de l'estil que no té parangó amb les altres reedicions del $F S$ català de la primera meitat de la centúria. Malauradament, aquesta edició valenciana no tornà a estampar-se.

Així mateix, en aquesta trajectòria editorial, diguem-ne, modulada per les dinàmiques del mercat, cal notar l'excepcionalitat de l'última edició, la de I575, revisada a bastament en el seu conjunt, però des d'una òptica diferent, més preocupada per millorar els aspectes doctrinals, d'acord als preceptes i manaments postridentins.

Aquesta primera aproximació a la qüestió, per tant, ha revelat dades interessants sobre la tradició editorial d'una obra principal en la tradició devota i espiritual. Entre d'altres aspectes, ens ha permés veure, per exemple, com, progressivament, amb la incorporació de nous capítols, la compilació es va allunyant cada vegada més del gruix original de Voràgine, per donar cabuda a devocions més significatives i representatives per als fidels. I de fet, aquest serà el camí per on 
continuarà desenvolupant-se l'hagiografia catalana del Siscents, per la recuperació i la difusió de les devocions pròpies, com evidencien els apunts hagiogràfics del jesuïta Pere Gil, sobre les Vides de sants de Catalunya (I6oo ca), o la Historia general de los santos y varones ilustres en santidad del Principado de Cataluña del dominic Antoni Vicenç Domènec (I602), primeres mostres representatives de l'hagiografia reformada catalana, i per tant, una nova etapa de la tradició hagiogràfica. 


\section{Obres citades}

Aguiló, Marià. 1923. Catálogo de obras en lengua catalana impresas desde 1474 hasta 1860 (Madrid: Sucesores de Rivadeneyra) <https://tinyurl.com/33rx97rs $>$

Aragüés Aldaz, José. 200O. 'El santoral castellano en los siglos XVI y XVII: un itinerario hagiográfico', Analecta Bollandiana, II8: 329-86 < $\underline{\text { https://doi.org/IO.I484/J.ABOL.4.00077> }}$

Aragüés Aldaz, José. 2004. 'Tendencias y realizaciones en el campo de la hagiografía en España', Memoria Ecclesiae, 24:44I-56o <https://tinyurl.com/3dxfz33b $>$

Aragüés Aldaz, José. 2005. 'Para el estudio del Flos sanctorum renacentista (I): la conformación de un genero', in Homenaje a Henri Guerreiro: la hagiografía entre historia y literatura en la España de la Edad Media y del Siglo de Oro, ed. by Marc Vitse (Madrid: Iberoamericana Vervuert), pp. 97-I47 〈https://doi.org/IO.3I8Ig/9783865279446-Oo8>

Aragüés Aldaz, José. 2OI2. 'Los flores sanctorum medievales y renacentistas: brevísimo panorama crítico', in Literatura medieval y renacentista en España: líneas y pautas, ed. by Natalia Fernández and María Fernández (Salamanca: SEMYR), pp. 349-6I < $\underline{\text { https://tinyurl. }}$ com/24ywbhd 4 >

Aragüés Aldaz, José. 20I6. 'Los legendarios medievales en la imprenta: La Leyenda de los santos', in La literatura medieval hispánica en la imprenta (1475-160o), ed. by M. Jesús Lacarra and Nuria Aranda (València: Universitat de València), pp. I7-35

Arco y Molinero, Ángel del. 19I5. 'Micer Juan de Sessé, precursor de los arqueólogos e historiadores tarraconenses', Boletín de la Real Academia de la Historia, 67: 263-80 < $\underline{\text { https:/ / tinyurl.com/ }}$ $\underline{\mathrm{yd} 5 \mathrm{rtdm}_{3}>}$

Arronis Llopis, Carme. In preparation. 'Catalan Lives of Saints after Trent (I575-I6O2)’.

Arronis Llopis, Carme. 202I. 'Sever de Barcelona en la primera hagiografia reformada', Specula, s: I53-I82 $<$ https://tinyurl.com/3knzpmnz $>$

Arronis Llopis, Carme. 20I5. La vida de la sacratíssima verge Maria de Miquel Peres (1494) (Alacant: Institut Interuniversitari de Filologia Valenciana; Barcelona: Publicacions de l’Abadia de Montserrat)

Arxiu del Real Col-legi del Corpus Christi de València $<\underline{\text { https://www.seminariocorpuschristi.org/ }}$ archivo-digital > [accessed IO-O8-2O2O]

Avenoza, Gemma; Garcia Sempere, Marinela. 2012. 'Santos y santas en la tradición escrita catalana medieval', in De lo humano y lo divino en la literatura medieval: Santos, ángeles y demonios, ed. by Juan Paredes (Granada: Universidad de Granada), pp. 47-6o < $\underline{\text { https://tinyurl.com/rpuzkjsy }>}$

Baños Vallejo, Fernando. 20I8a. 'La ilustración en las primeras ediciones peninsulares del flos sanctorum', in Espacios en la Edad Media y el Renacimiento, ed. by María Morrás (Salamanca: SEMYR), pp. I65-82

Baños Vallejo, Fernando. 20I8b. 'Paratextos, ilustración y autoridad en los flores sanctorum

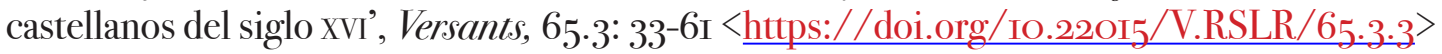

Baños Vallejo, Fernando. 2019. 'Lutero sobre la hagiografía y los hagiógrafos sobre Lutero', Studia Aurea, I3: 7-40 < $\underline{\text { https://doi.org/IO.5565/rev/studiaaurea. } 349}>$ 
Baños Vallejo, Fernando. 2020. 'Lanzarían grandes carcajadas: lo apócrifo del flos sanctorum y la burla de los protestantes', Rilce: Revista de Filología Hispánica, 36.2: $4_{228}-5^{2}<\underline{\text { https: / / doi. }}$ org/IO.I558I/OO8.36.2.428-52>

Betrán, José Luis. 20Io. 'Culto y devoción en la Cataluña barroca', Jerónimo Zurita, 85: 95-I32 $<$ https://tinyurl.com/33vavgye $>$

Betrán, José Luis. 2018. 'Entre el orden y el desorden: el clero diocesano barcelonés de la contrarreforma (I564-I700)', Studia Historica: Historia Moderna, 40.I: I85-232 <https://doi. org/IO.I420I/shhm020I840II85232>

BITECA. 1977-. Bibliografia de Textos Antics Catalans, Valencians i Balears, ed. by Vicenç Beltran et alii. (Berkeley: University of California) $<$ http://tinyurl.com/mzuqlzj $>$ [accessed IO-O2-2O2I]

Bizzarri, Hugo; Sainz de la Maza, Carlos. 1994. 'La Carta de Léntulo al senado de Roma: fortuna de un retrato de Cristo en la baja edad media castellana', Rilce: Revista de Filología Hispánica, Io.I: $45^{-5} 5^{8}<$ https://doi.org/IO.I558I/OO8.IO.I.43-58 $>$

Boesch-Gajano, Sofia. 1990. 'La raccolta di vite di santi di Luigi Lippomano: storia, struttura, finalità di una costruzione hagiogràfica', in Raccolte di vite di santi dal XIII al XVIII secolo: messaggi, strutture, fruizioni, ed. by Sofia Boesch-Gajano (Fasano di Brindisi: Schena), pp. IIO-3O

Cabasés, Fèlix Juan (ed.). 2007. Iacopo da Varazze, O.P. Leyenda de los santos (que vulgarment Flos Santorum llaman) [Sevilla, Juan Varela, I52O-2I] (Madrid: Universidad Pontificia de Comillas; Institutum Historicum Societatis Iesu)

Càmara Sempere, Hèctor. 20I3. El 'Flos Sanctorum Romançat': edició crítica dels dos incunables catalans de la Legenda aurea de Jacobus de Voragine (unpublished doctoral thesis, Universitat d'Alacant) <http://hdl.handle.net/I0045/7485I $>$

Càmara Sempere, Hèctor. 20I7. 'A muscles de gegant: els incunables del Flos sanctorum

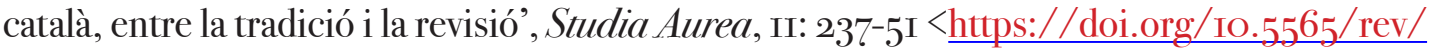
studiaaurea.254>

Canet, José Luis. 2005. 'Hagiografía valenciana (I470-I60o)', Cahiers de Framespa, I <https://doi. org/IO.4000/framespa.4II > [accessed I9-08-2O2I]

Collins, David J. 2008. Reforming Saints: Saints' Lives and Their Authors in Germany, 1470-1530 (New York: Oxford Scholarship Online) <https://doi.org/IO.Io93/ acprof:oso/9780I95329537.0OI.OOOI>

Colomer Amat, Emilia. 1995. 'Contribució a l'estudi dels Flos sanctorum catalans del segle Xv; una nova edició de Carles Amorós', Locus Amoenus, I: I2I-26 < https://doi.org/IO.5565/rev/ locus.33>

Colomer Amat, Emilia. 1999. 'El Flos sanctorum de Loyola y las distintas ediciones de la Leyenda de los santos: contribución al catálogo de Juan Varela de Salamanca', Analecta Sacra Tarraconensia, 72: Io9-42 $\langle$ https://www.bibliotecabalmes.cat/revista/I65 $>$

Comedic: Catálogo de obras medievales impresas en castellano hasta 16oo, ed. by Maria Jesús Lacarra (Zaragoza: Universidad de Zaragoza) <http://grupoclarisel.unizar.es/comedic/> [accessed 2O-O4-2O2I]

Courcelles, Dominique de. 1990. Les Histoires des saints, la prière et la mort en Catalogne (Paris: Publications de la Sorbonne) 
Domènec, Antoni Vicenç. I602. Historia general de los santos y varones ilustres en santidad del principado de Cataluña (Barcelona: Gabriel Graells \& Giraldo Dotil) $<$ https://tinyurl.com/ v93am2z8>

Dorca, Francisco. I796. Colección de noticias para la historia de los santos mártires de Gerona y de otras relativas a la Santa Iglesia de la misma Ciudad (Barcelona: Tecla Pla) < https://tinyurl. $\underline{\mathrm{com} / \text { rxtjum}_{33}>}$

Escartí, Vicent J. (ed.). 20II. Isabel de Villena Vita Christi(València: Alfons el Magnànim)

Establés Susán, Sandra. 20I8. Diccionario de mujeres impresoras y libreras de España e Iberoamérica entre los siglos XV y XVIII (Zaragoza: Universidad de Zaragoza)

Farías Muñoz, Laura. 20I7. 'Del text a l'estampa: representacions de Santa Madrona de Barcelona en la literatura d'època moderna', Matèria: Revista Internacional d'Art, I2: 7I-90 <https://doi. org/IO.I344/Materia20I7.I2.3>

Ferrer, Montserrat. 20IO. 'Notes on Catalan Translations of Devotional Literature with Special Reference to the Epistle of Lentulus to the Senate of Rome', in Humanism and Christian Letters in Early-modern Iberia (1480-1630), ed. by Barry Taylor and Alejandro Coroleu (Newcastle upon Tyne: Cambridge Scholars), pp. 47-6o

Flos sanctorum renacentista. I5I6. La vida y passión de nuestro señor Jesucristo, y las historias de las festividades de su sanctíssima madre, con las de los Santos apóstoles, mártires, confessores y vírgines (Zaragoza: Jorge Cocci)

Garcia Sempere, Marinela, et al. (ed.). In press. Flos sanctorum o Vides dels sants pares: Legenda aurea en català (Barcelona: Publicacions de l'Abadia de Montserrat)

Garcia Sempere, Marinela. 20I5. 'Algunes dades sobre els manuscrits de la versió catalana de la Legenda aurea', Medievalia, I8.2: I55-78 <https://doi.org/I0.5565/rev/medievalia.349>

Garcia Sempere, Marinela. 20I2a. 'Algunes notes sobre la difusió de les vides de sants a la península Ibèrica en els primers temps de la impremta', in Literatures ibèriques medievals comparades, ed. by Rafael Alemany and Francisco Chico (Alacant: Universitat d'Alacant), I: 247-56 <https:// tinyurl.com/3v38ssr5 $>$

Garcia Sempere, Marinela. 2OI2b. 'Vides de sants en català conservades en manuscrits solts i en impresos anteriors a I550', in Vides medievals de sants: difusió, tradició i llegenda, ed. by Marinela Garcia and M. Àngels Llorca (Alacant: Institut Interuniversitari de Filologia Valenciana), pp. $185^{-207}<\underline{\text { https: } / / \text { tinyurl.com/2jatkewf }}>$

Garcia Sempere, Marinela. 20Io. 'Vides exemplars en la literatura catalana medieval', in Actes del quinzè Col-loqui Internacional de Llengua i Literatura Catalanes, ed. by Imma Creus, Maite Puig and Joan R. Veny (Barcelona: Publicacions de l'Abadia de Montserrat), II: 95-IO4 < $\underline{\text { https:// }}$ tinyurl.com/snzgwwzh>

Garcia Sempere, Marinela; Wilkinson, Alexander. 2OII. 'La producció impresa en català dels segles XV i XVI: observacions sobre la història de la impremta a través de l'estudi dels catàlegs', Caplletra, 51: $5^{\text {I- }} 79$ <https://tinyurl.com/ 56 kmebsy $>$

Gelabertó Vilagran, Martí. 2003. La palabra del predicador: contrarreforma y superstición en Cataluña (siglos XVII-XVIII) (unpublished doctoral thesis, Universitat Autònoma de Barcelona) $<\underline{\text { https://tinyurl.com/bt8dhvyb }>}$ 
Gil, Pere. (ı6oo ca.). Vides dels sants de Catalunya, Biblioteca Pública Episcopal de Barcelona, MS 235

Iberian Books. 20I0-20I8. Iberian Books Database, ed, by Alexander Wilkinson (Dublin: University College Dublin) < https://iberian.ucd.ie/> [accessed IO-O5-2O2I]

Lacarra, María Jesús. 2020. 'El ciclo de imágenes del Cancionero de Zaragoza en los testimonios incunables (92VC y 95VC)', Revista de Poética Medieval, 34: IO7-30 < $\underline{\text { https://doi. }}$ org/IO.37536/RPM.202O.34·O.77845>

Lamarca, Montserrat. 20I5. La impremta a Barcelona (1501-1600) (Barcelona: Generalitat de Catalunya; Biblioteca de Catalunya) $<\underline{\text { https://tinyurl.com/upadk } 7 \mathrm{bz}}>$

Londoño, Marcela. 20I9. Las oraciones censuradas: superstición y devoción en los índices de libros prohibidos de España y Portugal (1551-1583) (Barcelona: Herder)

López Casas, Mercè. 20I8. 'Una altra traducció al catalá de La carta de Lèntul al Senat de Roma', in Edición y anotación de textos: actas del I Congreso de Jóvenes Filólogos, A Coruña 1996), ed. by Carmen Parrilla et al. (A Coruña: Universidade da Coruña), I: pp. $36 \mathrm{I}-7 \mathrm{O}<\underline{\text { https://ruc.udc.es/ }}$ $\underline{\text { dspace/handle/2I83/IO8O5 }>}$

López Casas, Mercè. 20I9. 'Versions hispàniques de la Carta de Pilat a Tiberi, in Actes del VII Congrés de l'Associació Hispànica de Literatura Medieval, Castelló 1997, ed. by Santiago Fortuño and Tomàs Martínez (Castelló de la Plana: Publicacions de la Universitat Jaume), II: 3O3-I4

Madurell Marimon, Josep M. I955. 'Llicències reials per l'edició de llibres piadosos catalans (I563- I704)', Analecta Sacra Tarraconensia, 28: 379-83 <https://www.bibliotecabalmes.cat/ revista/4I3>

Madurell Marimon, Josep. M. r966. 'L’antiga devoció popular barcelonina a sant Magí. Notes documentals per a la seva història', Butlletí Arqueològic: Reial Societat Arqueològica Tarraconense, 93-96: I6I-68 <https://tinyurl.com/3zvavsr5 $>$

Madurell Marimon, Josep Maria; Rubió i Balaguer, Jordi. 1955. Documentos para la historia de la imprenta y libreria en Barcelona (1474-1553) (Barcelona: Gremio de Editores, de Libreros y de Maestros Impresores)

Maggioni, Giovanni P. et al. (ed.). 2007. Iacopo da Varazze Legenda aurea: testo critico aggiornato con traduzione italiana, commento e note (Firenze: Edizioni del Galluzzo; Milano: Biblioteca Ambrosiana) $<$ https://go.uv.es/YZLG7j5>

Maneikis Kniazzeh, Charlotte; Neugaard, Edward (ed.). I977. Jacobus de Voragine Vides de sants rossellonesses, 3 vols (Barcelona: Fundació Salvador Vives Casajuana)

Martín del Burgo García, Lorenzo. 20I9. Una hagiografía de autor: la poética del 'Flos sanctorum' de Pedro de Ribadeneira (Santa Barbara University of California: Publications of eHumanista) $<$ https://tinyurl.com/vpnzgvde>

Miquel i Planas, Ramon. I9I6. Libre anomenat Vita Christi, 3 vols (Barcelona: Biblioteca Catalana)

Puig i Tàrrech, Armand. 2008. Els evangelis apòcrifs (Barcelona: Proa), vol. I

Rebull, Nolasc (ed.). 1976. Jaume de Voràgine Llegenda àuria (Olot: Aubert)

Romero Lucas, Diego. 2003. 'Un ejemplar valenciano de la Legenda aurea: el Flos sanctorum en catalán (Valencia, Jorge Costilla, I5I4)', in Actas del III encuentro Internacional de Filólogos 
Noveles, Valencia 2002, ed. by Carlos Alvar and Beatrice Schmid (Alcalá de Henares: Universidad de Alcalá; Basel: Universität Basel), pp. I83-98

Sandoval y Rojas, Bernardo. I6I4. Appendix prima ad Indicem librorum prohibitorum expurgatorum (Madrid: Luis Sánchez)

Serrano Morales, José Enrique. 1898-99. Reseña histórica en forma de diccionario de las imprentas que han existido en Valencia desde la introducción del arte tipográfico en España hasta el año 1868 con noticias bio-bibliográficas de los principales impresores (València: Impremta de F. Doménech) <http://links.uv.es/Igh6IdI $>$

Sobral, Cristina. 20I7. 'Um legendário à saída de Trento (Frei Diogo do Rosário, I567)', Studia Aurea, II: 253-72 $\langle\underline{\text { https://doi.org/IO.5565/rev/studiaaurea.245> }}$

Sobral, Cristina. 2002. 'O Flos sanctorum de I5I3 e suas adições portuguesas', Lusitania Sacra, I3I4: 53I-568 <http://hdl.handle.net/IO400.I4/ 4485 >

Thompson, Billy Bussell. 199o. 'Plumbei cordis, oris ferrei: la recepción de la teologia de Jacobus a Voragine y su Legenda aurea en la Península', in Saints and their Authors: Studies in Medieval Hispanic Hagiography in honor of John K. Walsh, ed. by Jane Connolly et al. (Madison: Hispanic Seminary of Medieval Studies), pp. 97-Io6

Tipobibliografía valenciana: siglos XV y XVI (València: Universitat de València) < https://parnaseo. uv.es/imprenta/publicacion/presentacion.html > [accessed IO-O2-2O2I]

Torres Amat, Fèlix. I836. Memorias para ayudar a formar un diccionario crítico de los escritores catalanes y dar alguna idea de la antigua y moderna literatura de Cataluña (Barcelona: Impremta de J. Verdaguer) $\langle$ https://tinyurl.com/kby8mxkw $>$

Valsalobre, Pep. 20I2. 'Elements per a una Catalunya sacra: sobre alguns aspectes de l'hagiografia de l'edat moderna catalana', in Vides medievals de sants: difusió, tradició i llegenda, ed. by Marinela Garcia and M. Àngels Llorca (Alacant: Institut Interuniversitari de Filologia Valenciana), pp. 99-I22

Vega, M. José. 20I4. 'Escandaloso, ofensivo y malsonante: censura y vigilancia de la prosa espiritual en la España del Siglo de Oro', Criticón, I2O-I2I: I37-54 <https://doi.org/IO.4000/ criticon.845>

Vega, Pedro de la (ed.). I540. La vida de nuestro señor Jesucristo, y de su sanctíssima madre, y de los otros sanctos, según la orden de sus fiestas [Flos sanctorum] (Sevilla: Juan Cromberger)

Vega, Pedro de la (ed.). I54I. La vida de nuestro señor Jesucristo, y de su sanctíssima madre, y de los otros sanctos, según la orden de sus fiestas [Flos sanctorum] (Zaragoza: Jorge Cocci)

\section{Annex: taules de correspondències}

\section{I Taula 1: Correspondència de capítols de l'Inc i ila LA}

Atés que, essencialment, les diferents edicions cinccentistes del $F S$ català reediten l'Inc. ${ }^{2}$ (Lió? I490-94), a la taula i es detalla l'índex de capítols d'aquest incunable, i per evidenciar les seues particularitats, es mostren les correspondències respecte de la $L A$ de Jacobus de Voragine 
(Maggioni ed. 2007). S’hi indica quins han estat els capítols omesos (om.), i les addicions (add.), bé en la tradició editorial del $F S$ català (és a dir, en els dos incunables), bé en l'Inc. ${ }^{2}$ exclusivament. $^{88}$

\begin{tabular}{|c|c|}
\hline Capítols del Flos sanctorum romançat Inc. ${ }^{2}$ & $L A$ \\
\hline Pròleg (f. II $\left.{ }^{a}\right)$ & Pròleg \\
\hline [I] De l'adveniment de nostre Senyor (f. II ${ }^{c}$ ) & [I] \\
\hline $\begin{array}{l}\text { [2] La interpretació de sant Andreu apòstol / La vida de sant } \\
\left.\text { Andreu (f. } V^{d}\right)\end{array}$ & {$[2]$} \\
\hline [3] De sant Longí (f. IXc) & [47] \\
\hline [4] De sancta Bàrbara (f. Xa) & add. $F S$ \\
\hline $\begin{array}{l}\text { [5] La interpretació de sant Nicholau (f. XII }{ }^{c} \text { ) / De sant } \\
\text { Nicholau (f. XII }{ }^{d} \text { ) }\end{array}$ & {$[3]$} \\
\hline [6] De sancta Lúcia (f. XVc) & $\begin{array}{l}\text { [4] } \\
\text { El FS omet l'etimologia inicial }\end{array}$ \\
\hline $\begin{array}{l}\text { [7] La interpretació de sant Thomàs apòstol / De sant } \\
\text { Thomàs (f. XVIc) }\end{array}$ & {$[5]$} \\
\hline [8] La Nativitat de Jesuchrist (f. XIX ${ }^{\mathrm{a}}$ ) & {$[6]$} \\
\hline [9] La vida de sancta Anastàsia (f. XXIc) & {$[7]$} \\
\hline [Io] La vida de sant Steve (f. XXII ${ }^{b}$ ) & $\begin{array}{l}{[8]} \\
\text { El } F S \text { omet l'etimologia inicial }\end{array}$ \\
\hline $\begin{array}{l}\text { [II] La interpretació de sanct Johan }\left(\mathrm{f} . \mathrm{XXIII^{ \textrm {d } } )} \text { / La vida de }\right. \\
\text { sant Johan apòstol e evangelista (f. XXIIII') }\end{array}$ & {$[9]$} \\
\hline [I2] Dels innocents (f. $X X V^{c}$ ) & $\begin{array}{l}\text { [ıo] } \\
\text { El } F S \text { omet l'etimologia inicial }\end{array}$ \\
\hline [I3] La vida de sant Thomàs de Contuberi (f. XXVId) & $\begin{array}{l}\text { [II] } \\
\text { El } F S \text { omet l'etimologia inicial }\end{array}$ \\
\hline [I4] La vida de sant Silvestre (f. XXVII ${ }^{d}$ ) & $\begin{array}{l}\text { [ı2] } \\
\text { El } F S \text { omet l'etimologia inicial }\end{array}$ \\
\hline [I5] De santa Coloma (f. XXX') & add. $F S$ \\
\hline [I6] La circuncisió de Jesuchrist (f. XXXI ${ }^{\mathrm{d}}$ ) & [І3] \\
\hline [I7] De san Amador (f. XXXIIII') & add. Inc. ${ }^{2}$ \\
\hline $\begin{array}{l}\text { [I8] Com nostre Senyor apparegué als tres reys d'Orient (f. } \\
X_{\left.X X V I^{a}\right)}\end{array}$ & [I4] \\
\hline $\begin{array}{l}\text { [I9] Comensa lo pròlech segons sant Hierònim sobre la } \\
\text { vida de sant Pau (f. XXXVIII }) \text { / La vida de sanct Pau primer } \\
\text { hermità (f. XXXVIII })\end{array}$ & {$[\mathrm{I} 5]$} \\
\hline [20] La vida de sanct Brandà (f. XL ${ }^{d}$ ) & add. $F S$ \\
\hline
\end{tabular}

88. Vid. a Càmara (2OI3: LII-LXI) una taula semblant centrada en la caracterització de l'Inc.'; inclou, a més, consideracions sobre les principals variacions en el contingut d'algunes vides. 


\begin{tabular}{|c|c|}
\hline Capítols del Flos sanctorum romançat Inc. ${ }^{2}$ & $L A$ \\
\hline [2I] De sant Remigi (f. XLII $\left.{ }^{d}\right)$ & $\begin{array}{l}\text { [I6] } \\
\text { El } F S \text { omet l'etimologia inicial }\end{array}$ \\
\hline [22] La vida de sant Hylari (f. XLIII') & $\begin{array}{l}\text { [I7] } \\
\text { El } F S \text { omet l'etimologia inicial }\end{array}$ \\
\hline [23] La vida de sant Machari (f. XLIIIIª) & $\begin{array}{l}\text { [18] } \\
\text { El } F S \text { omet l'etimologia inicial }\end{array}$ \\
\hline \multirow[t]{2}{*}{ [24] De sant Feliu in pincis (f. XLIIII') } & {$[\mathrm{Ig}]$} \\
\hline & $\begin{array}{l}\text { [20] De sancto Marcello } \\
\text { om. Inc. }{ }^{2}\end{array}$ \\
\hline [25] La vida de sant Anthoni (f. XLVa) & {$[2 \mathrm{I}]$} \\
\hline [26] De sant Johan Almoyner (f. XLVI ${ }^{d}$ ) & {$[27]$} \\
\hline $\begin{array}{l}\text { [27] La interpretació de sanct Fabià / La vida de sant Fabià } \\
\text { papa (f. XLVIII') }\end{array}$ & {$[22]$} \\
\hline $\begin{array}{l}\text { [28] La interpretació de sant Sebastià (f. XLIX'a) / De sant } \\
\text { Sebastià (f. XLIX }{ }^{b} \text { ) }\end{array}$ & {$[23]$} \\
\hline $\begin{array}{l}\text { [29] La interpretació de santa Agnés / De sancta Agnés (f. } \\
\mathrm{L}^{d} \text { ) }\end{array}$ & {$[24]$} \\
\hline \multirow{2}{*}{$\begin{array}{l}\text { [3o] La interpretació de sant Vincent / De sant Vincent (f. } \\
\mathrm{LI}^{\mathrm{d}} \text { ) }\end{array}$} & {$[25]$} \\
\hline & $\begin{array}{l}\text { [26] De sancto Basilio } \\
\text { om. FS }\end{array}$ \\
\hline [3I] La conversió de sant Pau apòstol (f. LII $\left.{ }^{d}\right)$ & {$[28]$} \\
\hline [32] La interpretació de sant Julià / De sant Julià (f. LIII $\left.{ }^{d}\right)$ & {$[3 \mathrm{O}]$} \\
\hline [33] La vida de santa Paula (f. LVb) & {$[29]$} \\
\hline $\begin{array}{l}\text { [34] Del temps de desviació / De la } \\
\text { Septuagèsima (f. LVII }{ }^{\mathrm{a}} \text { ) }\end{array}$ & [3і] \\
\hline [35] De la Sexagèsima (f. LVIIc) & {$[32]$} \\
\hline [36] De la Quinquagèsima (f. LVIII') & [33] \\
\hline [37] De la Quadragèsima (f. LVIII'b) & {$[34]$} \\
\hline [38] Dels quatre temps (f. LVIII $)$ & {$[35]$} \\
\hline [39] De sanct Ignaci (f. LIX ${ }^{\mathrm{b}}$ ) & {$[36]$} \\
\hline [40] De santa Brígida (f. LX') & add. Inc. ${ }^{2}$ \\
\hline [4I] De la Purificació de la Verge Maria (f. LXIª) & {$[37]$} \\
\hline $\begin{array}{l}\text { [42] La interpretació de sanct Blasi / La vida de sant Blasi (f. } \\
\text { LXIII') }\end{array}$ & {$[38]$} \\
\hline $\begin{array}{l}\text { [43] La interpretació de santa Àgatha (f. LXIIII') / De santa } \\
\text { Ägatha (f. LXIIII') }\end{array}$ & {$[39]$} \\
\hline [44] La vida de sancta Eulària verge (f. LXVc) & add. $F S$ \\
\hline
\end{tabular}




\begin{tabular}{|c|c|}
\hline Capítols del Flos sanctorum romançat Inc. ${ }^{2}$ & $L A$ \\
\hline \multirow[t]{3}{*}{ [45] La translació de sancta Eulària verge e màrtyr (f. LXVI } & add. $F S$ \\
\hline & $\begin{array}{l}\text { [40] De sancto Vedasto } \\
\text { om. Inc. }{ }^{2}\end{array}$ \\
\hline & $\begin{array}{l}\text { [4I] De sancto Amando } \\
\text { om. Inc. }{ }^{2}\end{array}$ \\
\hline $\begin{array}{l}\text { [46] La interpretació de sanct Valentí (f. LXVII }{ }^{\mathrm{b}} \text { ) / De sant } \\
\text { Valentí (f. LXVII') }\end{array}$ & {$[42]$} \\
\hline [47] La vida de santa Juliana (f. LXVIId) & [43] \\
\hline [48] De la cadira de sanct Pere apòstol (f. LXVIII') & {$[44]$} \\
\hline $\begin{array}{l}\text { [49] La interpretació de sant Macià / La vida de sant Macià (f. } \\
\text { LXIX }^{d} \text { ) }\end{array}$ & {$[45]$} \\
\hline [5o] La vida de sant Feliu prevere (f. LXXI') & [І22] \\
\hline $\begin{array}{l}\text { [5I] La interpretació de sanct Gregori / La vida de sanct } \\
\text { Gregori (f. LXXIc) }\end{array}$ & {$[46]$} \\
\hline $\begin{array}{l}\text { [52] La interpretació de sant Benet / De sant Benet (f. } \\
\text { LXXV }^{b} \text { ) }\end{array}$ & [48] \\
\hline [53] De sant Patrici (f. LXXVII') & [49] \\
\hline \multirow[t]{2}{*}{ [54] La Annunciació de la Verge Maria (f. LXXVIIIª) } & {$[5 \mathrm{O}]$} \\
\hline & $\begin{array}{l}\text { [5I] De Passione Domini } \\
\text { om. Inc. }{ }^{2}\end{array}$ \\
\hline \multirow[t]{2}{*}{ [55] De la Resurrectió de Jesuchrist (f. LXXX') } & {$\left[5^{2}\right]$} \\
\hline & $\begin{array}{l}\text { [53] De sancto Secundo } \\
\text { om. Inc. }{ }^{2}\end{array}$ \\
\hline [56] De santa Maria Egipciaca (f. LXXXIII') & {$[54]$} \\
\hline $\begin{array}{l}\text { [57] La interpretació de sanct Ambrós (f. LXXXIIII') / La } \\
\text { vida de sant Ambrós (f. LXXXIIII') }\end{array}$ & {$[55]$} \\
\hline [58] De sanct Vicens Ferrer (f. LXXXVIc) & add. Inc. ${ }^{2}$ \\
\hline $\begin{array}{l}\text { [59] La interpretació de sant Jordi / De sant Jordi (f. } \\
\text { LXXXVIIc) }\end{array}$ & {$[56]$} \\
\hline \multirow{2}{*}{$\begin{array}{l}\text { [6o] La interpretació de sant March evangelista (f. } \\
\text { LXXXVIII }^{d} \text { ) / La vida de sant March (f. LXXXIXª) }\end{array}$} & [57] \\
\hline & $\begin{array}{l}\text { [58] De sancto Marcellino } \\
\text { om. Inc. }{ }^{2}\end{array}$ \\
\hline $\begin{array}{l}\text { [6I] La interpretació de sant Vidal / La vida de sant Vidal (f. } \\
\text { LXXXIX }^{d} \text { ) }\end{array}$ & {$[59]$} \\
\hline [62] De una verge d'Antiochia (f. XCa) & {$[6 o]$} \\
\hline $\begin{array}{l}\text { [63] La interpretació de sanct Pere màrtyr / De sant Pere } \\
\text { màrtyr (f. XCc })\end{array}$ & {$[6 \mathrm{I}]$} \\
\hline
\end{tabular}




\begin{tabular}{|c|c|}
\hline Capítols del Flos sanctorum romançat Inc. ${ }^{2}$ & $L A$ \\
\hline $\begin{array}{l}\text { [64] La interpretació de sant Phelip / De sanct Phelip apòstol } \\
\text { (f. XCIIIr) }\end{array}$ & {$[62]$} \\
\hline $\begin{array}{l}\text { [65] La interpretació de sanct Jaume / De sanct Jaume } \\
\text { apòstol (f. XCIII') }\end{array}$ & {$[63]$} \\
\hline [66] Del trobament de la santa creu (f. XCVI') & [64] \\
\hline [67] La vida de sant Johan apòstol e evangelista (f. XCVII ${ }^{d}$ ) & {$[65]$} \\
\hline [68] De les letanies (f. XCVIII'a) & [66] \\
\hline [69] La Ascensió de Jesuchrist (f. XCIX'a) & {$[67]$} \\
\hline \multirow[t]{4}{*}{ [7o] Lo trametiment del Sanct Spirit (f. CI ${ }^{\mathrm{b}}$ ) } & [68] \\
\hline & $\begin{array}{l}\text { [69] De sanctis Gordiano et Epimacho } \\
\text { om. Inc. }{ }^{2}\end{array}$ \\
\hline & $\begin{array}{l}\text { [70] De sanctis Nereo et Achilleo } \\
\text { om. Inc. }{ }^{2}\end{array}$ \\
\hline & $\begin{array}{l}{\left[{ }_{7 \mathrm{I}}\right] \text { De sancto Pancratio }} \\
\text { om. Inc. } \\
\text { Inc. }{ }^{2} \text { om. només l'etimologia inicial }\end{array}$ \\
\hline [7I] La vida de santa Quitèria (f. CIIII' ${ }^{d}$ ) & add. $F S$ \\
\hline [72] De sant Onoffre (f. CVII' ${ }^{\mathrm{b}}$ ) & add. Inc. ${ }^{2}$ \\
\hline $\begin{array}{l}\text { [73] La interpretació de sanct Urban / La vida de sant Urban } \\
\text { (f. CX') }\end{array}$ & {$\left[7^{2}\right]$} \\
\hline [74] La vida de sant Guillem (f. CX ${ }^{\mathrm{b}}$ ) & add. $F S$ \\
\hline [75] De santa Petronil-la (f. CXIII') & {$[73]$} \\
\hline \multirow{2}{*}{$\begin{array}{l}\text { [76] La vida de sanct Pere exorcista e de sanct Marcel-lí (f. } \\
\text { CXIIII') }\end{array}$} & {$[74]$} \\
\hline & $\begin{array}{l}\text { [75] De sanctis Primo et Feliciano } \\
\text { om. Inc. }{ }^{2}\end{array}$ \\
\hline $\begin{array}{l}\text { [77] La interpretació de sant Barnabàs (f. CXIIII') / De sant } \\
\text { Barnabàs (f. CXIIII') }\end{array}$ & {$\left[7_{6}^{6}\right]$} \\
\hline [78] De sant Anthoni de Pàdua (f. CXV') & add. $F S$ \\
\hline $\begin{array}{l}\text { [79] La interpretació de sant Vitus e Modest / La vida de sant } \\
\text { Vitus e de Modest (f. CXVIc) }\end{array}$ & [77] \\
\hline $\begin{array}{l}\text { [8o] La interpretació de sanct Gervasi e de sanct Prothasi / } \\
\text { La vida de sant Gervasi e de sant Prothasi frares (f. CXVIIª) }\end{array}$ & {$[80]$} \\
\hline $\begin{array}{l}\text { [8I] La interpretació de sanct Johan Baptista (f. CXVII') / La } \\
\text { vida de sant Johan Baptista (f. CXVIII') }\end{array}$ & {$[8 \mathrm{I}]$} \\
\hline [82] La vida de sanct Johan e de sanct Pau (f. CXX') & [82] \\
\hline [83] De sant Leó papa (f. CXXI') & {$\left[8_{3}\right]$} \\
\hline $\begin{array}{l}\text { [84] La interpretació de sanct Pere apòstol / De sant Pere } \\
\left.\text { apòstol (f. CXXI }{ }^{d}\right)\end{array}$ & {$[84]$} \\
\hline
\end{tabular}




\begin{tabular}{|c|c|}
\hline Capítols del Flos sanctorum romançat Inc. ${ }^{2}$ & $L A$ \\
\hline $\begin{array}{l}\text { [85] La interpretació de sant Pau apòstol (f. CXXIIII') / De } \\
\text { sanct Pau apòstol (f. CXXIIII }{ }^{d} \text { ) }\end{array}$ & {$[85]$} \\
\hline [86] Dels VII frares e de la lur mare (f. CXXVI') & [86] \\
\hline \multirow[t]{2}{*}{ [87] Dels VII frares dormints (f. CXXVIc) } & [97] \\
\hline & $\begin{array}{l}{[87] \text { De sancto Syro }} \\
\text { om. FS }\end{array}$ \\
\hline [88] La vida de sancta Marina verge (f. CXXVII'c) & [79] \\
\hline $\begin{array}{l}\text { [89] La interpretació de santa Margarita (f. CXXVIII') / La } \\
\text { vida de sancta Margarita (f. CXXVIII') }\end{array}$ & [89] \\
\hline $\begin{array}{l}\text { [9o] La interpretació de sant Quiric (f. CXXIX }) \text { / La vida de } \\
\text { sant Quirich (f. CXXIXc) }\end{array}$ & {$\left[7^{8}\right]$} \\
\hline \multirow[t]{2}{*}{ [9I] La vida de sanct Alexi (f. CXXIX ${ }^{d}$ ) } & [9o] \\
\hline & $\begin{array}{l}\text { [9I] De sancta Praxede } \\
\text { om. FS }\end{array}$ \\
\hline $\begin{array}{l}\text { [92] La interpretació de santa Maria Magdalena / La vida de } \\
\text { sancta Maria Magdalena (f. CXXX') }\end{array}$ & {$[92]$} \\
\hline [93] De santa Martha (f. CXXXII ${ }^{\mathrm{d}}$ ) & [IOI] \\
\hline $\begin{array}{l}\text { [94] La interpretació de sanct Apol-linari / La vida de sant } \\
\text { Apol-linari (f. CXXXIII }{ }^{d} \text { ) }\end{array}$ & [93] \\
\hline $\begin{array}{l}\text { [95] La interpretació de santa Cristina (f. CXXXIIII') / La } \\
\text { vida de sancta Cristina (f. CXXXIIII') }\end{array}$ & [94] \\
\hline [96] De la vida de sanct Jaume apòstol (f. CXXXVª) & {$[95]$} \\
\hline $\begin{array}{l}\text { [97] La interpretació de sant Cristòfol / De sant Cristòfol (f. } \\
\text { CXXXVII }) \text { ) }\end{array}$ & {$[96]$} \\
\hline \multirow[t]{2}{*}{ [98] De sant Feliu e sant Cugat màrtirs (f. CXXXVIIII ${ }^{c}$ ) } & add. $F S$ \\
\hline & $\begin{array}{l}\text { [98] De sanctis Nazario et Celso } \\
\text { om. Inc. }{ }^{2}\end{array}$ \\
\hline \multirow[t]{2}{*}{ [99] De sant Feliu papa màrtyr (f. CXL ${ }^{a}$ ) } & [99] \\
\hline & $\begin{array}{l}\text { [Ioo] De sanctis Simplicio, Faustino et } \\
\text { Beatrice } \\
\text { om. Inc. }{ }^{2}\end{array}$ \\
\hline [ıoo] De sants Abdon e Sennén (f. CXLb) & [IO2] \\
\hline $\begin{array}{l}\text { [IOI] La interpretació de sant Germà (f. CXL'b) / De sant } \\
\text { Germà (f. CXLc) }\end{array}$ & [IO3] \\
\hline [IO2] De sant Feliu de Gerona (f. CXLIc ${ }^{c}$ ) & add. $F S$ \\
\hline [IO3] Dels VII frares machabeus (f. CXLII') & [105] \\
\hline \multirow[t]{2}{*}{ [IO4] Dels ligams de sanct Pere (f. CXLII' ${ }^{c}$ ) } & [ı6] \\
\hline & $\begin{array}{l}\text { [107] De sancto Stephano papa } \\
\text { om. Inc. }{ }^{2}\end{array}$ \\
\hline
\end{tabular}




\begin{tabular}{|c|c|}
\hline Capítols del Flos sanctorum romançat Inc. ${ }^{2}$ & $L A$ \\
\hline [IO5] Lo trobament de sanct Steve (f. CXLIIII'a) & [Іо8] \\
\hline $\begin{array}{l}\text { [Io6] La interpretació de sant Domingo (f. CXLV') / De sant } \\
\text { Domingo (f. CXLVc) }\end{array}$ & [Iog] \\
\hline $\begin{array}{l}\text { [IO7] La interpretació de sanct Sixto / La vida de sanct Sixto } \\
\left(\text { f. CL } L^{\mathrm{a}}\right)\end{array}$ & [ІІо $]$ \\
\hline $\begin{array}{l}\text { [Io8] La interpretació de sant Donat (f. CL } L^{b} \text { ) / La vida de } \\
\text { sanct Donat (f. CL } \text { ) }\end{array}$ & {$[\mathrm{IIII}]$} \\
\hline [Iog] La vida de sanct Ciríach (f. CLIª) & [II2] \\
\hline $\begin{array}{l}\text { [IIo] La interpretació de sanct Lorenç (f. CLIc) / La vida de } \\
\text { sant Lorens (f. CLI') }\end{array}$ & {$[\mathrm{II} 3]$} \\
\hline [III] De santa Clara (CLV $\left.{ }^{\mathrm{b}}\right)$ & add. $F S$ \\
\hline $\begin{array}{l}\text { [II2] La interpretació de sanct Ypòlit / La vida de sanct } \\
\text { Ypòlit (f. CLIX') }\end{array}$ & [II4] \\
\hline $\begin{array}{l}\text { [II3] La interpretació de sanct Eusebi / La vida de sanct } \\
\text { Eusebi (f. CLX') }\end{array}$ & [IO4] \\
\hline [II4] La Assumpció de la Verge Maria (f. CLXIª) & [II5] \\
\hline [II5] La vida de sant Roch (f. CLXVª) & add. Inc. ${ }^{2}$ \\
\hline $\begin{array}{l}\text { [II6] La interpretació de sanct Bernat abat / La vida de sanct } \\
\text { Bernat abat (f. CLXV') }\end{array}$ & [п6] \\
\hline $\begin{array}{l}\text { [II7] La interpretació de sanct Timotheu / La vida de sant } \\
\text { Timotheu (f. CLXVIII') }\end{array}$ & {$[\mathrm{II} 7]$} \\
\hline $\begin{array}{l}\text { [II8] La interpretació de sanct Simphorià / La vida de sanct } \\
\text { Simphorià (f. CLXVIII') }\end{array}$ & [ІІ8] \\
\hline $\begin{array}{l}\text { [Irg] La interpretació de sanct Bartholomeu (f. CLXVIII') / } \\
\text { De sant Barthomeu (f. CLXIXª) }\end{array}$ & [пу9] \\
\hline $\begin{array}{l}\text { [I20] La interpretació de sant Augustí / La vida de sant } \\
\text { Augustí (f. CLXX') }\end{array}$ & [120] \\
\hline [І2I] Lo degollament de sanct Johan Baptista (f. CLXXVb) & [I2I] \\
\hline [I22] La vida de sant Savià e de santa Saviana (f. CLXXVII') & [124] \\
\hline [I23] De sant Feliu prevere (f. CLXXVIII') & [122] \\
\hline [I24] La vida de sant Lop (f. CLXXVIII'c) & [125] \\
\hline \multirow{2}{*}{$\begin{array}{l}\text { [I25] La interpretació de sant Egidi / De sant Egidi (f. } \\
\text { CLXXIX }{ }^{\text {a) }}\end{array}$} & [І23] \\
\hline & $\begin{array}{l}\text { [126] De sancto Mamertino } \\
\text { om. Inc. }{ }^{2}\end{array}$ \\
\hline [i26] De la Nativitat de la Verge Maria (f. CLXXIX ${ }^{\mathrm{d}}$ ) & [127] \\
\hline \multirow[t]{2}{*}{ [I27] La vida de sant Adrià (f. CLXXXII') } & [128] \\
\hline & $\begin{array}{l}\text { [I29] De sanctis Gorgonio et Dorotheo } \\
\text { om. Inc. }{ }^{2}\end{array}$ \\
\hline
\end{tabular}




\begin{tabular}{|c|c|}
\hline \multirow[t]{2}{*}{ Capítols del Flos sanctorum romançat Inc. ${ }^{2}$} & $L A$ \\
\hline & $\begin{array}{l}\text { [130] De sanctis Protho et Iacincto } \\
\text { om. Inc. }{ }^{2}\end{array}$ \\
\hline \multirow{2}{*}{$\begin{array}{l}\text { [I28] Del exalçament de la santa creu (f. LXXXIIII') / Lo } \\
\text { celebrament de la santa creu (f. CLXXXIIII') }\end{array}$} & [I3I] \\
\hline & $\begin{array}{l}\text { [132] De sancto Iohanne Chrysostomo } \\
\text { om. FS }\end{array}$ \\
\hline $\begin{array}{l}\text { [129] La interpretació de sanct Corneli e de sant Cebrià / La } \\
\text { vida de sant Corneli e de sant Cebrià (f. CLXXXV') }\end{array}$ & [133] \\
\hline $\begin{array}{l}\text { [I3o] La interpretació de santa Eufèmia (f. CLXXXVIª) / La } \\
\text { vida de santa Eufèmia (f. CLXXXVI') }\end{array}$ & {$[\mathrm{I} 34]$} \\
\hline [I3I] De sant Lambert (f. CLXXXVId) & [I35] \\
\hline [132] De sant Eustachi (f. CLXXXVII'b) & [I57] \\
\hline $\begin{array}{l}\text { [I33] La interpretació de sanct Matheu apòstol / La vida de } \\
\text { sant Matheu (f. CLXXXVIII }{ }^{d} \text { ) }\end{array}$ & {$\left[\mathrm{I}_{3}^{6}\right]$} \\
\hline $\begin{array}{l}\text { [I34] La interpretació de sanct Maurici / La vida de sanct } \\
\text { Maurici (f. CXC') }\end{array}$ & {$[137]$} \\
\hline [135] La vida de santa Tecla (f. CXCI' ) & add. $F S$ \\
\hline $\begin{array}{l}\text { [I36] La interpretació de santa Justina verge / La vida de } \\
\text { santa Justina verge (f. CXCIIII }{ }^{\text {) }} \text { ) }\end{array}$ & [138] \\
\hline \multirow{2}{*}{$\begin{array}{l}\text { [137] La interpretació de sant Cosme e sant Damià / La vida } \\
\text { de sant Cosme e de sant Damià (f. CXCV })\end{array}$} & [139] \\
\hline & $\begin{array}{l}\text { [I } 40] \text { De sancto Forseo episcopo } \\
\text { om. FS }\end{array}$ \\
\hline [I38] La apparició de sanct Miquel archàngel (f. CXCVI') & [I4I $]$ \\
\hline $\begin{array}{l}\text { [I39] La interpretació de sant Hieronym (f. CXCIX') / La } \\
\text { vida de sant Hierònym (f. CGa) }\end{array}$ & [I42] \\
\hline \multirow{2}{*}{$\begin{array}{l}\text { [I40] La interpretació de sant Remigi / De sanct Remigi (f. } \\
\text { CCI }^{b} \text { ) }\end{array}$} & [I 433$]$ \\
\hline & $\begin{array}{l}\text { [I44] De sancto Leodegario } \\
\text { om. Inc. }{ }^{2}\end{array}$ \\
\hline \multirow{2}{*}{$\begin{array}{l}\text { [I4I] La interpretació de sant Francesc (f. CGI }{ }^{\text {d) }} \text { / De sant } \\
\text { Francesc (f. CCII }{ }^{a} \text { ) }\end{array}$} & {$[\mathrm{I} 45]$} \\
\hline & $\begin{array}{l}\text { [I } 47] \text { De sancta Margarita dicta } \\
\text { Pelagius } \\
\text { om. FS }\end{array}$ \\
\hline [I42] La vida de sanct Dyonís Ariopagita (f. CCIVd) & $\begin{array}{l}\text { [I } 49] \\
\text { El } F S \text { omet l'etimologia inicial }\end{array}$ \\
\hline [I43] De sant Calixto papa (f. CCVIa) & [I5o] \\
\hline $\begin{array}{l}\text { [I44] La interpretació de sant Luc evangelista / La vida de } \\
\text { sanct Luc evangelista (f. CCVI }{ }^{c} \text { ) }\end{array}$ & [I52] \\
\hline
\end{tabular}




\begin{tabular}{|c|c|}
\hline Capítols del Flos sanctorum romançat Inc. ${ }^{2}$ & $L A$ \\
\hline & $\begin{array}{l}\text { [i53] De sancto Crisanto } \\
\text { om. Inc. }{ }^{2}\end{array}$ \\
\hline [I45] De les onze mília vèrgens (f. CCVIII ${ }^{\mathrm{d}}$ ) & [I54] \\
\hline $\begin{array}{l}\text { [I46] La interpretació de sant Simon e Judes / De sant Simon } \\
\text { e Judes (f. CCX }{ }^{\text {a }} \text { ) }\end{array}$ & {$[\mathrm{I} 55]$} \\
\hline [I47] De sant Narcís de Gerona (f. CCXI') & add. $F S$ \\
\hline [I48] De sant Quintí (f. CCXIIc) & [I56] \\
\hline [I49] La festa de Tots Sants (f. CCXIId) & [I58] \\
\hline [I5o] Memòria de tots los faels defuncts (f. CCXV') & [I59] \\
\hline $\begin{array}{l}\text { [I5I] La interpretació de sant Leonart (f. CCXVIII' }) \text { / De } \\
\text { sanct Leonart (f. CCXVIII') }\end{array}$ & {$[\mathrm{I} 5 \mathrm{I}]$} \\
\hline [I52] Dels quatre coronats (f. CCXIX ${ }^{d}$ ) & [16o] \\
\hline [r53] De sant Theodori (f. CCXX') & [I6I] \\
\hline $\begin{array}{l}\text { [I54] La interpretació de sant Martí / De sant Martí (f. } \\
\text { CCXX }^{b} \text { ) }\end{array}$ & [162] \\
\hline [I55] La vida de sant Bres (f. CCXXII') & [I63] \\
\hline [I56] La vida de santa Elizabeth (f. CCXXIII') & [I64] \\
\hline $\begin{array}{l}\text { [I57] La interpretació de santa Cecília verge màrtyr (f. } \\
\text { CCXXV }^{d} \text { ) / De santa Cecília (f. CCXXVIª) }\end{array}$ & [I65] \\
\hline $\begin{array}{l}\text { [I58] La interpretació de sant Climent / De sant Climent (f. } \\
\text { CCXXVII }{ }^{b} \text { ) }\end{array}$ & [166] \\
\hline [I59] La vida de sant Grisogon (f. CCXXIXc) & [I67] \\
\hline $\begin{array}{l}\text { [I6o] La interpretació de santa Catherina / La vida de santa } \\
\text { Catherina (f. CCXXIX }{ }^{d} \text { ) }\end{array}$ & [168] \\
\hline [I6I] La vida de sant Sadorní (f. CCXXXI ${ }^{d}$ ) & [І69] \\
\hline [I62] De sanct Jaume entretallat (f. CCXXXII') & [17\%] \\
\hline [I63] La vida de sant Pastor (f. CCXXXIII') & {$[\mathrm{I} 7 \mathrm{I}]$} \\
\hline [I64] De sant Johan abat (f. CCXXXIIIIª) & [I72] \\
\hline [I65] De sant Moysés abat (f. CCXXXIIII') & [I73] \\
\hline [I66] La vida de sant Arseni (f. CCXXXIIII') & [I74] \\
\hline [I67] La vida de sant Agathon abat (f. CCXXXVIª) & [I75] \\
\hline [I68] La vida de sant Pafunci hermità (f. CCXXXVI'c) & add. $F S$ \\
\hline $\begin{array}{l}\text { [ı69] La vida de sant Pannuci hermità [Santa Eufrosina] (f. } \\
\text { CGXXXVIII') }\end{array}$ & add. $F S$ \\
\hline [I7o] La vida de santa Theodora (f. CCXL ${ }^{a}$ ) & [88] \\
\hline [I7I] De santa Thaycís (f. CCXLIª) & {$[148]$} \\
\hline [I72] De santa Pelàgia (f. CCXLI') & [I46] \\
\hline
\end{tabular}




\begin{tabular}{|c|c|}
\hline Capítols del Flos sanctorum romançat Inc. ${ }^{2}$ & $L A$ \\
\hline [I73] La vida de sant Pons (f. CCXLII ${ }^{\mathrm{b}}$ ) & add. $F S$ \\
\hline [I74] De santa Susanna (f. CCXLIIII' ${ }^{\mathrm{b}}$ ) & add. $F S$ \\
\hline $\begin{array}{l}\text { [I75] La vida de Barlam e com convertí Josaphat fill del rey } \\
\text { Avemir (f. CCXLVII') }\end{array}$ & [I76] \\
\hline [iz6] De sant Pelagi papa (f. CCLI ${ }^{\mathrm{d}}$ ) & \multirow{3}{*}{ [177] } \\
\hline [I77] La hystòria de Mahomet (f. CLIII') & \\
\hline [г78] Dels reys de Fransa (f. CCLIIII'ª) & \\
\hline [r79] De la dedicació de la Sglésia (f. CCLVIIª) & [І78] \\
\hline $\begin{array}{l}\text { [I80] La hystòria de santa Praxedis, cors sant de Mallorques } \\
(\text { f. CCLX') / La vida de santa Praxedis (f. CCLXIª) }\end{array}$ & add. $F S$ \\
\hline [I8I] La vida de sant Bernardí (f. CCLXIII') & add. $F S$ \\
\hline [I82] [Caterina de Siena] & {$[\text { add. FS] }]^{89}$} \\
\hline
\end{tabular}

\subsection{Taula 2: Correspondències de capítols entre els santorals del Cinccents}

I ${ }^{19}$ no ha estat considerat en aquesta taula, atés que reedita l'Inc. ${ }^{2}$ sense variacions de contingut.

\begin{tabular}{|c|c|c|c|c|}
\hline Inc. $^{2}$ & $I^{14}$ & $\mathbf{I}^{24}$ & I 47 & I 75 \\
\hline & & & & $\begin{array}{l}\text { [Pròleg] Ad pium } \\
\text { lectorem, f. [2] }]^{\mathrm{r}}\end{array}$ \\
\hline & & $\begin{array}{l}\text { [Avantpròleg] f. } \\
{\left[2^{\mathrm{a}}\right]}\end{array}$ & f. $[4]^{\mathrm{a}}$ & f. $[5]^{a}$ \\
\hline & & $\begin{array}{l}\text { [Pròleg de la } \\
\text { Passió] f. [2] }]^{\mathrm{a}}\end{array}$ & f. $[4]^{\mathrm{a}}$ & f. $[5]^{a}$ \\
\hline & & Passió f. [2] ${ }^{\mathrm{d}}$ & f. [4] $]^{\mathrm{c}}$ & f. $[5]^{c}$ \\
\hline & & $\begin{array}{l}\text { Publio Lèntulo } \\
\text { scriu la següent } \\
\text { letra als senadors } \\
\text { de Roma }[\mathrm{Io}]^{\mathrm{r}}\end{array}$ & f. [12 $]^{r}$ & f. $[9]^{v}$ \\
\hline & & $\begin{array}{l}\text { La segent [sic] } \\
\text { letra de Ponc } \\
\text { Pylat tramesa a } \\
\text { l'emperador Tiberi } \\
\text { Cèsar sobre la mort } \\
\text { e resurrectió de } \\
\text { Jesuchrist [Io] }{ }^{r}\end{array}$ & f. [12 $]^{r}$ & f. $[\mathrm{IO}]^{\mathrm{r}}$ \\
\hline
\end{tabular}

89. L'Inc. ${ }^{2}$ és incomplet per la fi, però atés que les edicions posteriors inclouen aquest capítol, present també en l'Inc. ${ }^{\mathrm{I}}$, és plausible considerar que Inc. ${ }^{2}$ ja l'incloguera. 


\begin{tabular}{|c|c|c|c|c|}
\hline Inc. $^{2}$ & $\mathbf{I}^{1 / 4}$ & $\mathbf{I}^{24}$ & I 47 & I 75 \\
\hline Pròleg $L A$ & f. $\mathrm{II}^{\mathrm{a}}$ & f. II ${ }^{\mathrm{a}}$ & f. II ${ }^{c}$ & f. $I^{c}$ \\
\hline [I] Advent & [I] f. II ${ }^{\mathrm{c}}$ & [I] f. II ${ }^{\mathrm{c}}$ & [I] f. II ${ }^{\mathrm{c}}$ & [I] f. I ${ }^{\mathrm{d}}$ \\
\hline [2] Andreu & {$[2] \mathrm{f} . \mathrm{V}^{\mathrm{d}}$} & [2] f. $\mathrm{V}^{\mathrm{d}}$ & [2] f. $\mathrm{V}^{\mathrm{d}}$ & [2] f. III ${ }^{\mathrm{a}}$ \\
\hline [3] Longí & [3] f. IX & [3] f. IX & [3] f. IXc & [3] f. VII ${ }^{\mathrm{a}}$ \\
\hline [4] Bàrbara & [4] f. $X^{\mathrm{a}}$ & [4] f. $X^{\mathrm{a}}$ & [4] f. $X^{\mathrm{a}}$ & [4] f. VII ${ }^{b}$ \\
\hline [5] Nicolau & {$[5]$ f. XII ${ }^{\mathrm{b}}$} & {$[5]$ f. XII ${ }^{b}$} & {$[5] f . X I^{\mathrm{d}}$} & {$[5]$ f. IX } \\
\hline [6] Llúcia & [6] f. $X V^{b}$ & [6] f. $X V^{b}$ & [6] f. XVI & [6] f. XI ${ }^{\mathrm{b}}$ \\
\hline [7] Tomàs & [7] f. XVI ${ }^{\mathrm{b}}$ & [7] f. XVI & [7] f. XVII ${ }^{\mathrm{c}}$ & {$[7]$ f. XII ${ }^{a}$} \\
\hline [8] Nadal & {$[8]$ f. XVIII $^{d}$} & [8] f. XIX[I8] ${ }^{c}$ & [8] f. $X X^{a}$ & [8] f. XIII ${ }^{\mathrm{d}}$ \\
\hline [9] Anastàsia & [9] f. XXI ${ }^{b}$ & [9] f. XXI & [9] f. XXIII ${ }^{\mathrm{a}}$ & {$[9] \mathrm{f} . X V^{d}$} \\
\hline [ı] Esteve & [Io] f. XXII ${ }^{\mathrm{a}}$ & [Io] f. XXI ${ }^{\mathrm{d}}$ & [Io] f. XXIIII' & [Iо] f. XVI ${ }^{\mathrm{b}}$ \\
\hline $\begin{array}{l}\text { [II] Joan } \\
\text { evangelista }\end{array}$ & [II] f. XXIII' & [II] f. XXIII & [II] f. XXVI & [II] f. XVII' \\
\hline $\begin{array}{l}\text { [I2] Sants } \\
\text { innocents }\end{array}$ & [I2] f. $X X V^{b}$ & [I2] f. XXIIII ${ }^{\mathrm{d}}$ & [I2] f. XXVIII' & [I2] f. XVIII ${ }^{\mathrm{c}}$ \\
\hline $\begin{array}{l}\text { [I3] Tomàs de } \\
\text { Canterbury }\end{array}$ & [I3] f. XXVI & [I3] f. XXVI ${ }^{a}$ & [I3] f. XXIX & [I3] f. XIX \\
\hline [I4] Silvestre & [I4] f. XXVII ${ }^{b}$ & [I4] f. XXVI ${ }^{\mathrm{d}}$ & [I 4 ] f. XXX & [I4] f. XX \\
\hline [15] Coloma & [I5] f. XXX' & [I5] f. XXIX' & [I5] f. XXXIIII' & [I5] f. XXII' \\
\hline [I6] Circumcisió & [I6] f. XXXI ${ }^{\mathrm{b}}$ & [I6] f. XXX" & [I6] f. XXXV' & [I6] f. XXIIII ${ }^{\mathrm{a}}$ \\
\hline [г7] Amador & [I7] f. XXXIIII & [I 7 f. XXXIII ${ }^{a}$ & [I]] f. XXXVIII' & [I7] f. XXIIII ${ }^{\mathrm{d}}$ \\
\hline [I8] Epifania & [I8] f. XXXV' & [I8] f. XXXIIII' & [I8] f. XL & [I8] f. XXVI ${ }^{\mathrm{a}}$ \\
\hline [19] Pau Ermità & [ז9] f. XXXVII ${ }^{\mathrm{d}}$ & [ı9] f. XXXVI ${ }^{\mathrm{d}}$ & [ı9] f. XLIII" ${ }^{\mathrm{a}}$ & [I9] f. XXVII ${ }^{\mathrm{d}}$ \\
\hline [20] Brandà & {$[2 \mathrm{O}] \mathrm{f} . X \mathrm{~L}^{\mathrm{c}}$} & [20] f. XXXIX' & [2o] f. XLVI ${ }^{\mathrm{a}}$ & [20] f. XXIX ${ }^{d}$ \\
\hline [2I] Remigi & [2I] f. XLII ${ }^{c}$ & {$[2 \mathrm{I}]$ f. XLI ${ }^{\mathrm{a}}$} & [2I] f. XLVIII ${ }^{b}$ & [2I] f. XXXI ${ }^{b}$ \\
\hline [22] Hilari & [22] f. XLIII ${ }^{\mathrm{a}}$ & {$[22]$ f. XLI $^{\mathrm{d}}$} & [22] f. XLIX ${ }^{\mathrm{a}}$ & [22] f. XXXI ${ }^{d}$ \\
\hline [23] Macari & {$[23]$ f. XLIII ${ }^{\mathrm{d}}$} & {$[23]$ f. XLII $^{\mathrm{b}}$} & {$[23]$ f. XLIX $^{\mathrm{d}}$} & {$[23]$ f. XXXII $^{\mathrm{b}}$} \\
\hline [24] Fèlix de Nola & [24] f. XLIIIII ${ }^{c}$ & [24]f. XLIII ${ }^{\mathrm{a}}$ & {$[24]$ f. $L^{c}$} & [24] f. XXXII \\
\hline [25] Antoni abat & {$[25]$ f. XLV } & [25] f. XLIII' ${ }^{\mathrm{c}}$ & {$[25] \mathrm{f}^{\mathrm{L}} \mathrm{LI}^{\mathrm{a}}$} & [25] f. XXXIII ${ }^{\mathrm{a}}$ \\
\hline $\begin{array}{l}{[26] \text { Joan }} \\
\text { Almoiner }\end{array}$ & [26] f. XLVI ${ }^{\mathrm{b}}$ & [26] f. XLV & [26] f. LIII ${ }^{\mathrm{a}}$ & [26] f. XXXIIII' \\
\hline [27] Fabià & {$[27]$ f. XLVIII ${ }^{d}$} & [27] f. XLVI ${ }^{\mathrm{d}}$ & [27] f. LV & {$[27]$ f. $X X X V^{d}$} \\
\hline [28] Sebastià & [28] f. XLIX ${ }^{\mathrm{a}}$ & [28] f. XLVII' & {$[28]$ f. $L V^{\mathrm{d}}$} & [28] f. XXXVI ${ }^{a}$ \\
\hline [29] Agnés & {$[29]$ f. L } & {$[29]$ f. XLVIII ${ }^{d}$} & [29] f. LVII ${ }^{c}$ & {$[29]$ f. XXXVIII } \\
\hline [30] Vicent & {$[3 \mathrm{O}] \mathrm{f}^{\mathrm{LII}}{ }^{\mathrm{a}}$} & [30] f. XLIX ${ }^{d}$ & [30] f. LVIII ${ }^{\mathrm{d}}$ & [3o] f. XXXVII \\
\hline
\end{tabular}




\begin{tabular}{|c|c|c|c|c|}
\hline Inc. $^{2}$ & $I^{1 / 4}$ & $I^{24}$ & I 47 & I 75 \\
\hline $\begin{array}{l}\text { [3I] Conversió de } \\
\text { sant Pau }\end{array}$ & [3I] f. LIII'b & {$[3 \mathrm{I}]$ f. $\mathrm{L}^{\mathrm{d}}$} & [3I] f. LX & [3] ] f. XXXVIII ${ }^{c}$ \\
\hline [32] Julià & [32] f. LIIII ${ }^{\mathrm{a}}$ & {$\left[3^{2}\right] \mathrm{f.} \mathrm{LI}^{\mathrm{c}}$} & {$\left[3^{2}\right]$ f. LXI $^{\mathrm{b}}$} & [32] f. XXXIX \\
\hline [33] Paula & [33] f. $\mathrm{LV}^{\mathrm{c}}$ & [33] f. LIII & [33] f. LXIII' & [33] f. $X X X^{b}$ \\
\hline [34] Septuagèsima & [34] f. LVII ${ }^{\mathrm{b}}$ & {$[34]$ f. LIIII $^{\mathrm{d}}$} & [34]f. LXV & [34]f. XXXI \\
\hline [35] Sexagèsima & {$[35]$ f. LVII $^{\mathrm{d}}$} & {$[35]$ f. $L V^{b}$} & {$[35]$ f. $L X V^{d}$} & [35] f. XXXII ${ }^{a}$ \\
\hline $\begin{array}{l}{[36]} \\
\text { Quinquagèsima }\end{array}$ & [36] f. LVIII ${ }^{a}$ & [36] f. $\mathrm{LV}^{\mathrm{c}}$ & [36] f. LXVI ${ }^{b}$ & [36] f. XXXII' \\
\hline [37] Quaresma & [37] f. LVIII' & {$[37]$ f. $\mathrm{LVI}^{\mathrm{a}}$} & [36] f. LXVI ${ }^{\mathrm{d}}$ & [37] f. XXXII ${ }^{\mathrm{d}}$ \\
\hline $\begin{array}{l}\text { [38] Dejú dels } \\
\text { quatre temps }\end{array}$ & [38] f. LIX & [38] f. LVI & [38] f. LXVII' & [38] f. XXXIII ${ }^{\mathrm{a}}$ \\
\hline [39] Ignasi & [39] f. LIX ${ }^{\mathrm{d}}$ & [39] f. LVII ${ }^{a}$ & [39] f. LXVIII ${ }^{\mathrm{a}}$ & [39] f. XXXIII \\
\hline [40] Brígida & [40] f. $\mathrm{LX}^{\mathrm{d}}$ & {$[40]$ f. $^{2}$ VII $^{\mathrm{d}}$} & [40] f. LXIX ${ }^{\mathrm{b}}$ & [40] f. XXXIIII' \\
\hline [4I] Purificació & [4I] f. LXI' & [4I] f. LVIIII ${ }^{b}$ & [4I] f. LXIX' & [4I] f. XXXIIII' \\
\hline [42] Blai & [42] f. LXIII ${ }^{\mathrm{d}}$ & {$\left[4_{2}\right]$ f. $L X^{d}$} & {$\left[4_{2}\right]$ f. LXXII $^{\mathrm{d}}$} & [42] f. XXXXVII ${ }^{d}$ \\
\hline [43] Àgata & [43] f. LXIIII ${ }^{\mathrm{d}}$ & [43] f. $\mathrm{LXI}^{\mathrm{d}}$ & [43] f. LXXIII' ${ }^{\mathrm{d}}$ & [43] f. XXXXVIII \\
\hline $\begin{array}{l}\text { [44] Eulàlia de } \\
\text { Barcelona }\end{array}$ & [44] f. LXVI' & [44] f. LXIII" & [44] f. LXXV" & {$[44] \mathrm{f} . \mathrm{IL}^{\mathrm{c}}$} \\
\hline $\begin{array}{l}\text { [45] Translació de } \\
\text { les despulles de } \\
\text { santa Eulàlia }\end{array}$ & [45] f. LXVII ${ }^{b}$ & [45] f. LXIII' ${ }^{d}$ & [45] f. LXXVI ${ }^{c}$ & [45]f. $\mathrm{L}^{\mathrm{a}}$ \\
\hline [46] Valentí & [46] f. $\mathrm{LXX}^{\mathrm{a}}$ & [46] f. LXIIII ${ }^{c}$ & [46] f. LXXVII ${ }^{\mathrm{c}}$ & [46] f. $\mathrm{L}^{\mathrm{c}}$ \\
\hline [47] Juliana & [47] f. LXX' & [47] f. $L X V^{a}$ & [47] f. LXXVIII ${ }^{\mathrm{a}}$ & [47] f. LI ${ }^{\mathrm{a}}$ \\
\hline $\begin{array}{l}\text { [48] Càtedra de } \\
\text { sant Pere }\end{array}$ & [48] f. LXIXa & [48] f. $L X V^{c}$ & [48] f. LXXVIII ${ }^{c}$ & [48] f. $\mathrm{LI}^{\mathrm{d}}$ \\
\hline [49] Macià & [49] f. LXX' & [49] f. LXVI ${ }^{\mathrm{d}}$ & [49] f. LXXX' & [49] f. LII ${ }^{d}$ \\
\hline [5o] Feliu prevere & [5o] f. LXXII & [5o] f. LXVIIII & [5o] f. LXXXII ${ }^{\mathrm{a}}$ & {$[5 \mathrm{O}]$ f. LIII $^{\mathrm{d}}$} \\
\hline [5I] Gregori & [5I] f. LXXII' & {$\left[5^{\mathrm{I}}\right]$ f. LXVIII ${ }^{\mathrm{c}}$} & {$\left[5^{\mathrm{I}}\right]$ f. LXXXII ${ }^{\mathrm{b}}$} & [5ㅍ f. LIIII' \\
\hline [52] Benet & [52] f. LXXVI ${ }^{\mathrm{c}}$ & [52] f. LXXII ${ }^{a}$ & [52] f. LXXXVI & {$\left[5^{2}\right] \mathrm{f}^{\mathrm{LVV}} \mathrm{d}^{\mathrm{d}}$} \\
\hline [53] Patrici & [53] f. LXXVIII & [53] f. LXXIIII ${ }^{a}$ & [53] f. LXXXIX & {$[53]$ f. LVIII $^{\mathrm{c}}$} \\
\hline [54] Anunciació & [54] f. LXXIX' & [54] f. LXXIIII ${ }^{\mathrm{d}}$ & [54]f. XC & {$[54]$ f. LIX ${ }^{\mathrm{a}}$} \\
\hline [55] Resurrecció & {$[55]^{\text {f. }} \mathrm{LXXXI}^{\mathrm{d}}$} & [55] f. LXXVI ${ }^{\mathrm{d}}$ & [55] f. XCII ${ }^{\mathrm{d}}$ & [55] f. $L X^{\mathrm{d}}$ \\
\hline $\begin{array}{l}\text { [56] Maria } \\
\text { Egipcíaca }\end{array}$ & [56] f. LXXXV' & [56] f. LXXX & {$\left[5^{6}\right] \mathrm{f} \cdot \mathrm{XCVI}{ }^{\mathrm{d}}$} & [56] f. LXIII \\
\hline [57] Ambrós & [57] f. LXXXVI ${ }^{\mathrm{b}}$ & [57] f. LXXX & [57] f. XCVII ${ }^{c}$ & [57] f. LXIII' \\
\hline [58] Vicent Ferrer & [58] f. LXXXVIII ${ }^{d}$ & [58] f. LXXXII' & [58] f. Ci & {$\left[5^{8}\right]$ f. $L X V^{b}$} \\
\hline [59] Jordi & [59] f. LXXXIX & [59] f. LXXXIII ${ }^{c}$ & [59] f. CI ${ }^{\mathrm{a}}$ & [59] f. LXVI \\
\hline
\end{tabular}




\begin{tabular}{|c|c|c|c|c|}
\hline Inc. $^{2}$ & $\mathrm{I}^{4}$ & $I^{24}$ & I 47 & I 75 \\
\hline [6o] Marc & {$[6 o]$ f. XCI $^{\mathrm{a}}$} & {$[6 o]$ f. LXXXV } & [6o] f. CIII ${ }^{\mathrm{a}}$ & [6o] f. LXVII ${ }^{\mathrm{a}}$ \\
\hline [6r] Vidal & [6I] f. XCII ${ }^{a}$ & [6I] f. LXXXV & [6I] f. CIIII ${ }^{\mathrm{a}}$ & [6I] f. LXVII ${ }^{\mathrm{c}}$ \\
\hline $\begin{array}{l}\text { [62] Verge } \\
\text { d'Antioquia }\end{array}$ & {$[62]$ f. XCII ${ }^{c}$} & [62] f. LXXXVI & [62] f. CIIII ${ }^{c}$ & [62] f. LXVIII ${ }^{a}$ \\
\hline [63] Pere màrtir & {$\left[6_{3}\right]$ f. XCIII ${ }^{a}$} & [63] f. LXXXVI & [63] f. CIIII ${ }^{\mathrm{d}}$ & [63] f. LXVIII' \\
\hline [64] Felip & {$[64]$ f. XCV } & {$[64]$ f. LXXXIX } & [64] f. CVIII ${ }^{b}$ & {$[64]$ f. LXX ${ }^{c}$} \\
\hline [65] Jaume & [65] f. XCVI ${ }^{\mathrm{c}}$ & {$[65]$ f. LXXXIX } & {$\left[6_{5}\right]$ f. CIX ${ }^{\mathrm{a}}$} & {$[65]$ f. LXX } \\
\hline $\begin{array}{l}\text { [66] Invenció de la } \\
\text { Creu }\end{array}$ & [66] f. XCIX ${ }^{\mathrm{d}}$ & [66] f. CXI[9I ${ }^{\mathrm{d}}$ & [66] f. CXI ${ }^{\mathrm{c}}$ & [66] f. LXXII ${ }^{c}$ \\
\hline $\begin{array}{l}{[67] \text { Joan }} \\
\text { evangelista }\end{array}$ & {$\left[6_{7}\right]$ f. Cc } & [67] f. XCIII' & [67] f. CXIII ${ }^{c}$ & {$\left[6_{7}\right]$ f. LXXIII' } \\
\hline [68] Lletanies & [68] f. CI ${ }^{\mathrm{a}}$ & [68] f. XCIII ${ }^{\mathrm{d}}$ & [68] f. CXIIII ${ }^{\mathrm{a}}$ & [68] f. LXXIIII ${ }^{\mathrm{a}}$ \\
\hline [69] Ascensió & [69] f. CII ${ }^{\mathrm{a}}$ & [69] f. XCIIII ${ }^{c}$ & [69] f. CXV & [69] f. LXXIIII' \\
\hline [7o] Pentecosta & [7\%] f. CIIII ${ }^{\mathrm{c}}$ & {$\left[{ }_{7} \mathrm{O}\right] \mathrm{f} \cdot \mathrm{XCVI}{ }^{\mathrm{d}}$} & {$[7 \mathrm{O}] \mathrm{f} . \mathrm{CXVIII}{ }^{\mathrm{a}}$} & [7o] f. LXXVI ${ }^{c}$ \\
\hline [7I] Quitèria & [7] ] f. CVIIII ${ }^{c}$ & [7] $]$ f. $\mathrm{C}^{\mathrm{b}}$ & [7r] f. CXXII ${ }^{b}$ & [7] I] f. LXXIX ${ }^{a}$ \\
\hline [72] Onofre & {$\left[7^{2}\right]$ f. CXI $^{\mathrm{a}}$} & [72] f. CII ${ }^{\mathrm{c}}$ & [72] f. CXXV & [72] f. LXXX \\
\hline [73] Urbà & [73] f. CXIII ${ }^{\mathrm{d}}$ & [73] f. CV & [73] f. CXXVIII ${ }^{\mathrm{a}}$ & [73] f. LXXXIIc \\
\hline [74] Guillem & [74] f. CXIIII ${ }^{\mathrm{a}}$ & [74] f. CV & [74] f. CXXVIII" & [74] f. LXXXII \\
\hline [75] Petronil.la & [75] f. CXVII ${ }^{\mathrm{d}}$ & [75] f. CVIIII ${ }^{\mathrm{c}}$ & [75] f. CXXXII & [75] f. LXXXVb \\
\hline $\begin{array}{l}{[76] \text { Pere exorcista }} \\
\text { i Marcel-lí }\end{array}$ & [76] f. CXVIII ${ }^{\mathrm{a}}$ & [76] f. CIX ${ }^{\mathrm{a}}$ & [76] f. CXXXIII ${ }^{a}$ & [76]f. LXXXV" \\
\hline [77] Bernabé & [77] f. CXVIII ${ }^{c}$ & [77] f. CIX ${ }^{\mathrm{b}}$ & [77] f. CXXXII' & [77] f. LXXXV \\
\hline $\begin{array}{l}\text { [78] Antoni de } \\
\text { Pàdua }\end{array}$ & [78] f. CXX & [78] f. CXc & [78] f. CXXXV"a & {$\left[7^{8}\right]$ f. LXXXVI } \\
\hline [79] Vitus i Modest & [79] f. CXX & [79] f. CXI ${ }^{\mathrm{b}}$ & [79] f. CXXXV & [79] f. LXXXVII' \\
\hline \multirow{2}{*}{$\begin{array}{l}\text { [8o] Gervasi i } \\
\text { Protasi }\end{array}$} & [8o] f. CXXI ${ }^{b}$ & {$[8 \mathrm{o}]$ f. CXI $^{\mathrm{d}}$} & {$[80]$ f. CXXXVI ${ }^{\mathrm{c}}$} & [8o] f. LXXXVII \\
\hline & $\begin{array}{l}\text { [8I] La hystòria } \\
\text { dels deu mila } \\
\text { cavallers } \\
\text { crucificats, f. } \\
\text { CXXII }^{\text {b }}\end{array}$ & & & {$[\mathrm{rgI}]^{90}, \mathrm{f} \mathrm{CCIX}^{\mathrm{a}}$} \\
\hline [8I] Joan Baptista & [82] f. CXXIIII' & [8I] f. CXII ${ }^{\mathrm{c}}$ & [8I] f. CXXXVII & [8I] f. LXXXVIII \\
\hline [82] Joan i Pau & [83] f. CXXVII & [82] f. CXV ${ }^{\mathrm{a}}$ & [82] f. CXL ${ }^{\mathrm{c}}$ & [82] f. LXXXX' \\
\hline [83] Lleó & [84] f. CXXVII ${ }^{\mathrm{d}}$ & [83] f. CXV ${ }^{d}$ & [83] f. CXLI ${ }^{\mathrm{c}}$ & [83] f. LXXXXI ${ }^{\mathrm{a}}$ \\
\hline
\end{tabular}

9o. Es tracta, però, d’una versió diferent. 


\begin{tabular}{|c|c|c|c|c|}
\hline Inc. $^{2}$ & $I^{\mathbf{H}_{4}}$ & $\mathbf{I}^{24}$ & I 47 & I 75 \\
\hline & & & $\begin{array}{l}\text { [84] La vida de } \\
\text { sanct Justy sanct } \\
\text { Pastor, f. CXLII }\end{array}$ & [182] f. CG \\
\hline [84] Pere & [85] f. CXXVIIII & [84] f. CXVI ${ }^{\mathrm{a}}$ & {$\left[8_{5}\right]$ f. CXLII $^{\mathrm{d}}$} & [84] f. LXXXXI ${ }^{b}$ \\
\hline [85] Pau & [86] f. CXXXI ${ }^{b}$ & [85] f. CXVIII ${ }^{d}$ & [86] f. CXLVI ${ }^{\mathrm{a}}$ & {$[85]^{91} \mathrm{LXXXXIII}$} \\
\hline $\begin{array}{l}\text { [86] Set germans i } \\
\text { Felicitat }\end{array}$ & [87] f. CXXXIII & [86] f. CXX' & [87] f. CXLVIII' & \\
\hline $\begin{array}{l}\text { [87] Set dorments } \\
\text { d'Efes }\end{array}$ & [88] f. CXXXIII' & {$\left[8_{7}\right]$ f. CXX } & [88] f. CXLVIII ${ }^{c}$ & [86] f. LXXXXIIII ${ }^{\mathrm{d}}$ \\
\hline [88] Marina & [89] f. CXXXIIII' & [88] f. CXXI ${ }^{\mathrm{d}}$ & [89] f. CXLIX & {$[(87)]^{9^{2}}$} \\
\hline \multirow[t]{2}{*}{ [89] Margarita } & [9o] f. CXXXV" & [89] f. CXXII & [9o] f. CL & {$[(88)]$} \\
\hline & & & $\begin{array}{l}\text { [9I] La vida de } \\
\text { sant Magí, f. CLI }\end{array}$ & [I83] f. CCI ${ }^{\mathrm{a}}$ \\
\hline [9o] Quirze & [9I] f. CXXXVI ${ }^{b}$ & [9o] f. CXXIII' ${ }^{\mathrm{c}}$ & [92] f. CLIII ${ }^{c}$ & [89] f. LXXXV \\
\hline [9I] Aleix & [92] f. CXXXVI ${ }^{\mathrm{d}}$ & [9I] f. CXXIII ${ }^{\mathrm{d}}$ & [93] f. CLIIII ${ }^{a}$ & [9o]f. LXXXV"a \\
\hline [92] Magdalena & [93] f. CXXXVII ${ }^{\mathrm{d}}$ & [92] f. CXXIIII' & [94] f. CLV ${ }^{b}$ & [9I] f. LXXXV \\
\hline [93] Marta & [94]f. CXL & [93] f. CXXVI ${ }^{\mathrm{d}}$ & [95] f. CLVII ${ }^{\mathrm{d}}$ & [92] f. XCVII ${ }^{b}$ \\
\hline [94] Apol-linar & [95] f. CXLI ${ }^{b}$ & [94] f. CXXVII ${ }^{\mathrm{d}}$ & [96] f. CLVIII ${ }^{\mathrm{d}}$ & [93] f. XCVIII ${ }^{\mathrm{a}}$ \\
\hline [95] Cristina & [96] f. CXLII ${ }^{a}$ & [95] f. CXXVIII' & [97] f. CLIX' & [94] f. XCVIIIc \\
\hline [96] Jaume apòstol & [97] f. CXLII ${ }^{\mathrm{d}}$ & [96] f. CXXVIIII ${ }^{\mathrm{a}}$ & [98] f. CLX ${ }^{b}$ & [95] f. XCVIIII' \\
\hline [97] Cristòfol & [98] f. CXLV ${ }^{\mathrm{a}}$ & [97] f. CXXI[I3I $]^{\mathrm{a}}$ & [99] f. CLXIII ${ }^{\mathrm{a}}$ & [96] f. $\mathrm{C}^{\mathrm{d}}$ \\
\hline [98] Feliu i Cugat & [99] f. CXLVI & [98] f. CXXII[I32] & [IOo] f. CLXIIII' ${ }^{\mathrm{c}}$ & [97] f. CI ${ }^{\mathrm{d}}$ \\
\hline [99] Feliu papa & [Iоo] f. CXLVII ${ }^{\mathrm{d}}$ & [99] f. CXXXIII ${ }^{\mathrm{c}}$ & [IOI] f. CLXVI' & [98] f. CII ${ }^{\mathrm{d}}$ \\
\hline $\begin{array}{l}\text { [ıoo] Abdó i } \\
\text { Senén }\end{array}$ & [IoI] f. CXLVIII ${ }^{a}$ & [Ioo] f. CXXXIII & [IO2] f. CLXVI' & [99] f. CII ${ }^{\mathrm{d}}$ \\
\hline [IOI] Germà & [IO2] f. CXLVIII' & [IOI] f. CXXXIIII & [Io3] f. CLXVI ${ }^{\mathrm{c}}$ & [IOO] f. CIII ${ }^{\mathrm{a}}$ \\
\hline $\begin{array}{l}\text { [IO2] Feliu de } \\
\text { Girona }\end{array}$ & [Io3] f. CXLIX & [IO2] f. CXXXIIII' & [IO4] f. CLXVII ${ }^{\mathrm{d}}$ & [IOI] f. CIII' \\
\hline $\begin{array}{l}\text { [Io3] Set Germans } \\
\text { macabeus }\end{array}$ & [IO4] f. CL ${ }^{b}$ & [Io3] f. CXXXV d & [Io5] f. CLXVIIII & [IO2] f. CIIII ${ }^{c}$ \\
\hline $\begin{array}{l}\text { [IO4] Pere } \\
\text { encadenat }\end{array}$ & [IO5] f. CL ${ }^{\mathrm{c}}$ & [IO4] f. CXXXVI & [Io6] f. CLXIX a & [Iо3] f. CIIII ${ }^{\mathrm{d}}$ \\
\hline $\begin{array}{l}\text { [IO5] Invenció del } \\
\text { cos de sant Esteve }\end{array}$ & [Io6] f. CLII' & [Io5] f. CXXXVII & [Io7] f. CLXX & [IO4] f. CV d \\
\hline
\end{tabular}

9I. L’exemplar no conserva el f. LXXXXIII on començaria el capítol.

92. L'exemplar no conserva aquest foli, que tindria una numeració errònia; per l'extensió, assumisc que inclouria els capítols corresponents que apareixen en la resta d'edicions del santoral. 


\begin{tabular}{|c|c|c|c|c|}
\hline Inc. $^{2}$ & $I^{4}$ & $\mathbf{I}^{24}$ & I 47 & I 75 \\
\hline [Io6] Domènec & [IO?] f. CLIII' & $\begin{array}{l}\text { [Io6] f. } \\
\text { CXXXVIII }^{c}\end{array}$ & [Io8] f. CLXXII & [IO5] f. CVI ${ }^{\mathrm{c}}$ \\
\hline [IO7] Sixt & [Io8] f. CLVIII' & $\begin{array}{l}\text { [IO]] f. } \\
\text { CXXXXIII }^{\text {a }}\end{array}$ & [ıog] f. CLXXVII ${ }^{\mathrm{d}}$ & [Io6] f. CX \\
\hline [IO8] Donat & [Iog] f. CLVIII ${ }^{\mathrm{d}}$ & $\begin{array}{l}\text { [Iо8] f. } \\
\text { CXXXXIII' }\end{array}$ & [IIo] f. CLXXVIII & [IO?] f. CX \\
\hline [ıog] Ciriac & [IIO] f. CLIX' & $\begin{array}{l}\text { [Iog] f. } \\
\text { CXXXXIIIII }^{2}\end{array}$ & [III] f. CLXXIX' & [Io8] f. CX \\
\hline [IIO] Llorenç & [III] f. CLX ${ }^{\mathrm{a}}$ & $\begin{array}{l}\text { [ноо] f. } \\
\text { CXXXXIIII }^{c}\end{array}$ & [II2] f. CLXXIX' & [Iog] f. CXI ${ }^{\mathrm{a}}$ \\
\hline [III] Clara & [II2] f. CLXIII ${ }^{c}$ & $\begin{array}{l}\text { [III] f. } \\
\text { CXXXXVIII }\end{array}$ & [ıI3] f. CLXXXIII ${ }^{\mathrm{d}}$ & [IIO] f. CXIIII \\
\hline [II2] Hipòlit & [ı̈3] f. CLXVIII ${ }^{a}$ & [II2] f. CLII ${ }^{\mathrm{a}}$ & $\begin{array}{l}\text { [II4] f. } \\
\text { CLXXXVIII }^{d}\end{array}$ & [II4] f. CXVII ${ }^{c}$ \\
\hline [II3] Eusebi & [II4] f. CLXIX & [ıI3] f. CLIII ${ }^{a}$ & [II5] f. CXCa & [III] f. CXVII(II6) \\
\hline [II4] Assumpció & [II5] f. CLXIX d & [II4] f. CLIII ${ }^{c}$ & [II6] f. CXCi & [II5] f. CXVIII ${ }^{\mathrm{a}}$ \\
\hline [II5] Roc & [ıт6] f. CLXXIIII & [II5] f. CLVII ${ }^{\mathrm{b}}$ & {$\left[\mathrm{II}_{7}\right]$ f. CXCV ${ }^{\mathrm{b}}$} & [II6] f. CXXI ${ }^{a}$ \\
\hline [н16] Bernat & [II7] f. CLXXIIII ${ }^{b}$ & [ıा6] f. CLVII & [ı8] f. CXCV & [II7] f. CXXI \\
\hline [II7] Timoteu & [ıі8] f. CLXXVII ${ }^{\mathrm{a}}$ & [ı̈] f. CLXX ${ }^{b}$ & [IIg] f. CXCVIIII ${ }^{\mathrm{a}}$ & {$\left[\begin{array}{l}{[\mathrm{I} 2]} \\
\mathrm{d}\end{array}\right.$} \\
\hline [II8] Simforià & [ırg] f. CLXXVII ${ }^{b}$ & [ıв] f. CLXX" & [I20] f. CXCVIIII' & [ıз3] f. CXVII ${ }^{\mathrm{a}}$ \\
\hline [ıт] Bartomeu & [120] f. CLXXVII ${ }^{d}$ & [ı19] f. CLXI ${ }^{\mathrm{a}}$ & [I2I] f. CXCVIIII & [ı8] f. CXXIII \\
\hline [120] Agustí & [I2I] f. CLXXIX & [I2O] f. CLXII' & [I22] f. CGI ${ }^{\mathrm{c}}$ & [ıI9] f. CXXIIII' \\
\hline $\begin{array}{l}\text { [I2I] Degollament } \\
\text { de Joan Baptista }\end{array}$ & $\begin{array}{l}\text { [I22] f. } \\
\text { CLXXXIIII' }\end{array}$ & [І2I] f. CLXVII ${ }^{\mathrm{a}}$ & [I23] ${ }^{93}$ f. CCVII $^{\mathrm{b}}$ & [I20] f. CXXVIII ${ }^{\mathrm{a}}$ \\
\hline $\begin{array}{l}\text { [I22] Savià i } \\
\text { Saviana }\end{array}$ & [ı23] f. CLXXXVI & [I22] f. CLXIX & [I24] f. CGIXc & [I2I] f. CXXIX \\
\hline [123] Feliu prevere & $\begin{array}{l}\text { [I24] f. } \\
\text { CLXXXVII }\end{array}$ & [I23] f. CLXIX & [I25] f. CCX' & \\
\hline [I24] Llop & $\begin{array}{l}\text { [I25] f. } \\
\text { CLXXXVII }^{c}\end{array}$ & [I24] f. CLXX & [г26] f. CCXI"a & [ı22] f. CXXX \\
\hline [I25] Egidi & $\begin{array}{l}\text { [І26] f. } \\
\text { CLXXXVIII }{ }^{\mathrm{a}}\end{array}$ & [I25] f. CLXX' & [І27] f. CCXI' & [ı23] f. CXXX' \\
\hline $\begin{array}{l}\text { [I26] Nativitat de } \\
\text { Maria }\end{array}$ & $\begin{array}{l}\text { [I27] f. } \\
\text { CLXXXXVIII }^{d}\end{array}$ & [ı26] f. CLXXI & [ı28] f. CCXII & [ı24] f. CXXXI \\
\hline [I27] Adrià & [ı28] f. CXCII ${ }^{\mathrm{a}}$ & [เ27] f. CLXXIIII' & [ı29] f. CCXVI"a & [I25] f. CXXXIII" \\
\hline
\end{tabular}

93. El contingut dels folis CCII i CCVII està intercanviat. 


\begin{tabular}{|c|c|c|c|c|}
\hline Inc. $^{2}$ & $I^{1 / 4}$ & $I^{24}$ & I 47 & I 75 \\
\hline $\begin{array}{l}\text { [128] Exaltació de } \\
\text { la Creu }\end{array}$ & [I29] f. CXCII[I] ${ }^{\mathrm{b}}$ & [ז28] f. CLXXV & [I3o] f. CCXVII ${ }^{c}$ & [ı26] f. CXXXIIII' \\
\hline $\begin{array}{l}\text { [129] Corneli i } \\
\text { Cebrià }\end{array}$ & [г3o] f. CXCVª & [I29] f. CLXXVII ${ }^{\mathrm{a}}$ & [г3г] f. CCXIX ${ }^{c}$ & [I27] f. CXXXV \\
\hline [130] Eufèmia & [гзг f. CXCV ${ }^{c}$ & [13o] f. CLXXVII ${ }^{\mathrm{b}}$ & [132] f. CCXX & [ז28] f. CXXXVI ${ }^{\mathrm{a}}$ \\
\hline [I3I] Lambert & [I32] f. CXCVI ${ }^{\mathrm{b}}$ & [I3I] f. CLXXVIII ${ }^{\mathrm{a}}$ & [I33] f. CCXX & [I29] f. CXXXVI ${ }^{\mathrm{c}}$ \\
\hline [I32] Eustaqui & [I33] f. CXCVI ${ }^{\mathrm{d}}$ & [I32] f. CLXXVIII' & [I34] f. CCXXI ${ }^{b}$ & [I3o] f. CXXXVI \\
\hline [г33] Mateu & [I34] f. CXCVIII ${ }^{b}$ & [I33] f. CLXXIX ${ }^{\mathrm{d}}$ & [135] f. CCXXIII ${ }^{\mathrm{a}}$ & [I3I] f. CXXXVIII ${ }^{a}$ \\
\hline [134] Maurici & [I35] f. CCa & [I34] f. CLXXXI ${ }^{b}$ & {$[(\mathrm{I} 36)]^{94}$} & [I32] f. CXXXIX \\
\hline [г35] Tecla & [136] f. CC $\mathrm{CC}^{\mathrm{d}}$ & [I35] f. CLXXXII ${ }^{c}$ & [(137)] & [ı33] f. CXXXX \\
\hline [I36] Justina & [ı37] f. CCIIII ${ }^{\mathrm{a}}$ & [I36] f. CLXXXV ${ }^{\mathrm{a}}$ & {$[(138)]$} & [I34] f. CXXXXII \\
\hline $\begin{array}{l}\text { [I37] Cosme i } \\
\text { Damià }\end{array}$ & [138] f. CGV & [I37] f. CLXXXVI' & {$[(139)]$} & [I35] f. CXXXXIII \\
\hline $\begin{array}{l}\text { [I38] Miquel } \\
\text { arcàngel }\end{array}$ & [I39] f. CGVI ${ }^{b}$ & $\begin{array}{l}\text { [I38] f. } \\
\text { CLXXXVII }\end{array}$ & $\begin{array}{l}\text { [I } 40 \text { ] f. } \\
\text { CCXXXIII }^{a}\end{array}$ & [136] f. CXXXXIII \\
\hline [r39] Jeroni & [I 4 O] f. CCX ${ }^{\mathrm{a}}$ & [I39] f. CXCc & [I4I] f. CCXXXVI ${ }^{\mathrm{a}}$ & [I37] f. CXXXXVI \\
\hline [I40] Remigi & [I/4I] f. CCXI ${ }^{c}$ & [I4O] f. CXCI ${ }^{d}$ & $\begin{array}{l}\text { [I42] f. } \\
\text { CCXXXVII }^{\mathrm{d}}\end{array}$ & $\begin{array}{l}\text { [138] f. } \\
\text { CXXXXVII }\end{array}$ \\
\hline [I4I] Francesc & [I42] f. CCXII ${ }^{\mathrm{a}}$ & $\begin{array}{l}\text { [I4I] f. } \\
\text { CLXXXXII }^{c}\end{array}$ & $\begin{array}{l}\text { [I43] f. } \\
\text { CCXXXVIII }^{c}\end{array}$ & $\begin{array}{l}\text { [I39]f. } \\
\text { CXXXXVII }^{d}\end{array}$ \\
\hline $\begin{array}{l}\text { [I42] Dionís } \\
\text { Areopagita }\end{array}$ & [I43] f. CCXV ${ }^{\mathrm{a}}$ & $\begin{array}{l}\text { [I42] f. } \\
\text { CLXXXV[195] }\end{array}$ & $\begin{array}{l}\text { [I44] f. } \\
\text { CCXLI[242] }\end{array}$ & $\begin{array}{l}\text { [I40] f. } \\
\text { CXXXXVIIII }^{d}\end{array}$ \\
\hline [I43] Calixt & [I44] f. CCXVI' & $\begin{array}{l}\text { [ז43] f. } \\
\text { CLXXXVI[ı66] }\end{array}$ & [I 45] f. CCXLIII' & [I4I] f. CL ${ }^{d}$ \\
\hline [I44] Lluc & [I 45$]^{\text {f. CCXVI }}{ }^{\mathrm{d}}$ & $\begin{array}{l}\text { [I44]f. } \\
\text { CLXXXVI[I96] }^{\mathrm{d}}\end{array}$ & {$\left[\mathrm{I}_{4} 6\right]$ f. CCXLIII $^{\mathrm{d}}$} & [I 42$]$ f. CLI $^{\mathrm{a}}$ \\
\hline $\begin{array}{l}\text { [I45] Onze mil } \\
\text { verges }\end{array}$ & [I46] f. CCXIX & [I 45] f. CIC ${ }^{\mathrm{a}}$ & [I 47] f. CCXLVI ${ }^{\mathrm{d}}$ & [I43] f. CLIII' ${ }^{\mathrm{a}}$ \\
\hline [I46] Simó i Judes & [I 47 ] f. CCXX' & [I46] f. CC & $\begin{array}{l}\text { [I48] f. } \\
\text { CCXLVIII }^{\mathrm{a}}\end{array}$ & [I44] f. CLIII ${ }^{\mathrm{d}}$ \\
\hline [I47] Narcís & [I48] f. CCXXII ${ }^{a}$ & [I47] f. CCI ${ }^{\mathrm{c}}$ & [I 49] f. CCXLIX ${ }^{d}$ & [I 45] f. CLIIIII ${ }^{\mathrm{d}}$ \\
\hline [I48] Quintí & [I49] f. CCXXIII ${ }^{\mathrm{a}}$ & [I48] f. CCII ${ }^{\mathrm{c}}$ & [I5o] f. CCLI ${ }^{\mathrm{a}}$ & [I46] f. CLV ${ }^{\mathrm{c}}$ \\
\hline [I49] Tots Sants & [I5o] f. CCXXIIII & [I49] f. CCII ${ }^{\mathrm{d}}$ & [I5I] f. CCLI' & [I47] f. CLV \\
\hline [I50] Difunts & [I5I] f. CCXXVI ${ }^{b}$ & [I5o] f. $\mathrm{CCV}^{\mathrm{c}}$ & {$\left[{ }^{5} 5^{2}\right]$ f. CCLIIII $^{\mathrm{c}}$} & [I48] f. CLVIII' \\
\hline [I5I] Leonard & [I52] f. CCXXIX' & [i5I] f. CGVIII' & [I53] f. CCLVIII ${ }^{\mathrm{a}}$ & [I49] f. CLX ${ }^{\mathrm{a}}$ \\
\hline
\end{tabular}

94. L'únic testimoni d'I ${ }^{47}$ conservat no conté els folis 225-232; per l'extensió, assumisc que inclouria els capítols corresponents que apareixen en la resta d'edicions del santoral. 


\begin{tabular}{|c|c|c|c|c|}
\hline Inc. $^{2}$ & $I^{14}$ & $\mathbf{I}^{24}$ & $\mathbf{I}+7$ & I 75 \\
\hline $\begin{array}{l}\text { [I52] Quatre } \\
\text { coronats }\end{array}$ & [I53] f. CCXXX' & [I52] f. CCVIIII' & [I54] f. CCLIX & [I5o] f. CLXI ${ }^{\mathrm{a}}$ \\
\hline [I53] Teodor & [I54] f. CCXXX' & [I53] f. CCVIIIII & [I55] f. CCLIX ${ }^{c}$ & [155] f. CLXI ${ }^{b}$ \\
\hline [I54] Martí & [i55] f. CCXXXI ${ }^{a}$ & [I54] f. CCX ${ }^{\mathrm{a}}$ & [I56] f. CCLX $X^{\mathrm{a}}$ & [I52] f. CLXI ${ }^{b}$ \\
\hline [I55] Breç & $\begin{array}{l}\text { [I56] f. } \\
\text { CCXXXIIII }\end{array}$ & [I55] f. CCXII ${ }^{\mathrm{a}}$ & [i57] f. CCLXII' & [I53] f. CLXII ${ }^{\mathrm{a}}$ \\
\hline [ı56] Elizabeth & [157] f. CCXXXIII ${ }^{d}$ & [I56] f. CCXII & [I58] f. CCLXIII ${ }^{\mathrm{a}}$ & [I54] f. CLXII' \\
\hline [ı57] Cecília & $\begin{array}{l}\text { [I58] f. } \\
\text { CGXXXVI }^{\mathrm{d}}\end{array}$ & [I57] f. CCXV & [I59] f. CCLXVI & [I55] f. CLXV \\
\hline [158] Climent & $\begin{array}{l}\text { [I59] f. } \\
\text { CCXXXVIII }^{b}\end{array}$ & [I58] f. CCXVI & [I6o] f. CCLXVII ${ }^{d}$ & [I56] f. CLXVI \\
\hline [I59] Crisògon & [I6o] f. CCXL ${ }^{c}$ & [I59] f. CCXVIII ${ }^{\mathrm{d}}$ & [I6I] f. CCLXX" & [I57] f. CLXVIIII \\
\hline [I6o] Caterina & [I6I] f. CCXLI ${ }^{a}$ & [I6o] f. CCXIX ${ }^{\mathrm{a}}$ & [I62] f. CCLXXI ${ }^{\mathrm{a}}$ & [I58] f. CLXVIIII \\
\hline [I6I] Sadurní & [I62] f. CCXLIII ${ }^{b}$ & [I6I] f. CCXXI ${ }^{\mathrm{a}}$ & [I63] f. CCLXXIII' & [I59] f. CLXX \\
\hline $\begin{array}{l}\text { [162] Jaume } \\
\text { l'intercís }\end{array}$ & [ı63] f. CCXLIII' & [I62] f. CCXXI & $\begin{array}{l}\text { [164] f. } \\
\text { CGLXXIIII }\end{array}$ & [I6o] f. CLXX' \\
\hline [ı63] Pastor & [I64] f. CCXLIIII ${ }^{\mathrm{d}}$ & [I63] f. CCXXII ${ }^{\mathrm{c}}$ & [I65] f. CCLXXV & [I6I] f. CLXXI ${ }^{\mathrm{a}}$ \\
\hline [I64] Joan abat & [I65] f. CCXLV & [I64] f. CCXXIII ${ }^{a}$ & [ı66] f. CCLXXVV & [I62] f. CLXXI ${ }^{c}$ \\
\hline [165] Moisés & [I66] f. CCXLV ${ }^{d}$ & [I65] f. CCXXIIII & [I67] f. CCLXXVI" & [I63] f. CLXXI ${ }^{\mathrm{d}}$ \\
\hline [I66] Arseni & [i67] f. CCXLVI ${ }^{\mathrm{b}}$ & [I66] f. CCXXIII' & $\begin{array}{l}\text { [I68] f. } \\
\text { CCLXXVI }^{\mathrm{d}}\end{array}$ & [I64] f. CLXXII ${ }^{\mathrm{a}}$ \\
\hline [ı67] Agató & [I68] f. CCXLVII ${ }^{\mathrm{c}}$ & [I67] f. CCXXX & $\begin{array}{l}\text { [I69] f. } \\
\text { CCLXXVIII }\end{array}$ & [I65] f. CLXXIII"a \\
\hline [I68] Pafnuci & [I69] f. CCXLVIII ${ }^{\mathrm{a}}$ & [ı68] f. CCXXX' & $\begin{array}{l}\text { [I7o] f. } \\
\text { CCLXXVIII }^{d}\end{array}$ & [ı66] f. CLXXIIII \\
\hline [I69] [Eufrosina] & [I7o] f. CCXLIX' & [I69] f. CCXXXI ${ }^{\mathrm{d}}$ & [I7I] f. CCLXXX ${ }^{b}$ & [I67] f. CLXXIIII' \\
\hline [Izo] Teodora & [I7 I] f. CCLI ${ }^{\mathrm{d}}$ & $\begin{array}{l}\text { [I70] f. } \\
\text { CCXXXIII }\end{array}$ & $\begin{array}{l}\text { [I72] f. } \\
\text { CCLXXXII }\end{array}$ & [I68] f. CLXXVII \\
\hline [IzI] Taís & [I72] f. CCLII ${ }^{\mathrm{d}}$ & $\begin{array}{l}{[\mathrm{I} 7 \mathrm{I}] \mathrm{f} .} \\
\text { CCXXXIIII }^{\mathrm{d}}\end{array}$ & $\begin{array}{l}\text { [I73] f. } \\
\text { CCLXXXIIII }^{\mathrm{a}}\end{array}$ & [I69] f. CLXXVII \\
\hline [I72] Pelàgia & [I73] f. CCLIII' & [172] f. CCXXXV & $\begin{array}{l}\text { [I74] f. } \\
\text { CCLXXXIIII }\end{array}$ & [I7o] f. CLXXVII ${ }^{a}$ \\
\hline [I73] Ponç & [I74] f. CCLIIII ${ }^{\mathrm{a}}$ & [I73] f. CCXXXV & $\begin{array}{l}\text { [I75] f. } \\
\text { CCLXXXVb }\end{array}$ & [I7I] f. CLXXVII ${ }^{c}$ \\
\hline [I74] Susanna & [I75] f. CCLVI ${ }^{\mathrm{a}}$ & $\begin{array}{l}\text { [I74] f. } \\
\text { CCXXXVII }^{\mathrm{d}}\end{array}$ & & [I72] f. CLXXIX \\
\hline [I75] Barlaam & [I76] f. CCLIX ${ }^{\mathrm{a}}$ & [I 75$]$ f. CCXL ${ }^{\mathrm{c}}$ & & [I73] f. CLXXXXI \\
\hline [I76] Pelagi & [I77] f. CCLXIII' & [I 76$]$ f. CCXLVª & $\begin{array}{l}\text { [Iz6] f. } \\
\text { CCLXXXVII }\end{array}$ & $\begin{array}{l}\text { [I74] f. } \\
\text { CLXXXXIIII }\end{array}$ \\
\hline
\end{tabular}




\begin{tabular}{|c|c|c|c|c|}
\hline Inc. $^{2}$ & $\mathrm{I}^{4}$ & $I^{24}$ & I 47 & I 75 \\
\hline [I77] Mahoma & [I78] f. CCLXIIII" & [I77] f. CCXLV & & \\
\hline [I78] Reis francs & [I79] f. CCLXVI & $\begin{array}{l}\text { [I78] f. } \\
\text { CCXLVII }{ }^{\mathrm{a}}\end{array}$ & & \\
\hline $\begin{array}{l}\text { [I79] Dedicació de } \\
\text { l'església }\end{array}$ & [I8o] f. CCLXIX' & [I79] f. CCL ${ }^{a}$ & & $\begin{array}{l}\text { [I75] f. } \\
\text { CLXXXXVb }\end{array}$ \\
\hline [I80] Praxedis & [I8I] f. CCLXXIII & [I8o] f. CCLIII ${ }^{\mathrm{d}}$ & $\begin{array}{l}\text { [I77] f. } \\
\text { CCLXXXVIII }\end{array}$ & $\begin{array}{l}\text { [I76] f. } \\
\text { CLXXXXVIII }\end{array}$ \\
\hline [I8I] Bernardí & [I82] f. CCLXXVI ${ }^{\mathrm{a}}$ & [I8I] f. CCLVI ${ }^{\mathrm{b}}$ & [I78] f. CCXCI ${ }^{\mathrm{d}}$ & [177] f. $\mathrm{CXC}^{\mathrm{a}}$ \\
\hline \multirow[t]{8}{*}{$\begin{array}{l}\text { [182] [Caterina de } \\
\text { Siena] }\end{array}$} & [I83] f. CCLXXX & [I82] f. CCLVIIII ${ }^{\mathrm{d}}$ & [I79] f. CCXCVI ${ }^{\mathrm{b}}$ & $\begin{array}{l}\text { [178] f. } \\
\text { CVCII }[192]^{\mathrm{c}}\end{array}$ \\
\hline & & $\begin{array}{l}\text { [183] La vida } \\
\text { del gloriós sanct } \\
\text { Sever, màrtyry } \\
\text { bisbe de la ciutat } \\
\text { de Barcelona, f. } \\
\text { CCLXV }\end{array}$ & [I8o] f. CCCII ${ }^{\mathrm{b}}$ & [I79] f. CXCVI ${ }^{\mathrm{d}}$ \\
\hline & & $\begin{array}{l}\text { [I84] La vida de } \\
\text { sancta Madrona, f. } \\
\text { CCLXVI }^{\mathrm{a}}\end{array}$ & [I8I] f. CCCIII ${ }^{\mathrm{c}}$ & [I8o] f. CXCVII ${ }^{c}$ \\
\hline & & $\begin{array}{l}\text { [185] La vida de } \\
\text { sant Sagimon, qui } \\
\text { fonch fill del rey } \\
\text { de Burguanya, f. } \\
\text { CCLXVII }^{\mathrm{a}}\end{array}$ & [I82] f. CCCIIII' & [I8I] f. CXCVIII' \\
\hline & & & $\begin{array}{l}\text { [183] La vida de } \\
\text { sanct Serapió } \\
\text { màrtyr, f. } \\
\text { CCCVIII }^{\mathrm{a}}\end{array}$ & [184] f. CCII ${ }^{b}$ \\
\hline & & $\begin{array}{l}\text { [I86] La vida de } \\
\text { la benaventurada } \\
\text { santa Anna, mare } \\
\text { de la gloriosa } \\
\text { verge Maria, f. } \\
\text { CCLXIX }\end{array}$ & [I84] f. CCCVIII ${ }^{c}$ & \\
\hline & & $\begin{array}{l}\text { [I87] Comença la } \\
\text { ystòria de la festa } \\
\text { dels sancts àngels } \\
\text { que nos guardan, } \\
\text { que.s nomena } \\
\text { l'Àngel Custodi, f. } \\
\text { CCLXXI }^{\mathrm{d}}\end{array}$ & [I86], f. CCCXI' & \\
\hline & & & $\begin{array}{l}\text { [185] La vida de } \\
\text { sancta Escolàstica, } \\
\text { f. CCCX }{ }^{c}\end{array}$ & \\
\hline
\end{tabular}




\begin{tabular}{|c|c|c|c|c|}
\hline Inc. $^{2}$ & $I^{14}$ & $I^{24}$ & $\mathbf{I} 47$ & I 75 \\
\hline & & & $\begin{array}{l}\text { [187] La vida } \\
\text { del gloriós } \\
\text { sanct Honorat, } \\
\text { arquebisbe de } \\
\text { Arlés, f. CCCXIII }\end{array}$ & [I85] f. CCII ${ }^{c}$ \\
\hline & & & $\begin{array}{l}\text { [I88] La vida } \\
\text { del gloriós sanct } \\
\text { Elm, advocat } \\
\text { dels mariners, lo } \\
\text { qual tostemps } \\
\text { està prompte } \\
\text { en lur ajuda, f. } \\
\text { CCCXIII }^{c}\end{array}$ & [I86] f. CCII ${ }^{d}$ \\
\hline & & & $\begin{array}{l}\text { [I89] La vida } \\
\text { del gloriós sanct } \\
\text { Bertran, bisbe } \\
\text { y confessor, } \mathrm{f} \text {. } \\
\text { CCCXVII }^{b}\end{array}$ & [I87] f. CCV \\
\hline & & & & $\begin{array}{l}\text { [188] La vida del } \\
\text { gloriós sanct Yvo, } \mathrm{f} \text {. } \\
\mathrm{CGV}^{\mathrm{c}}\end{array}$ \\
\hline & & & & $\begin{array}{l}\text { [I89] Vida } \\
\text { y miraclesy } \\
\text { canonisatió } \\
\text { del gloriós sant } \\
\text { Francisco de } \\
\text { Paula, confessor, } \\
\text { fundador de l'orde } \\
\text { dels Mínims, / La } \\
\text { canonització de } \\
\text { sanct Francisco de } \\
\text { Paula, f. CCV }\end{array}$ \\
\hline & & & & $\begin{array}{l}\text { [19o] La vida } \\
\text { de sanct Basili, f. } \\
\text { CGVII }^{\mathrm{d}}\end{array}$ \\
\hline & & & & $\begin{array}{l}\text { [192] La vida de } \\
\text { sancta Otília, f. } \\
\text { CCIX }^{c}\end{array}$ \\
\hline
\end{tabular}

